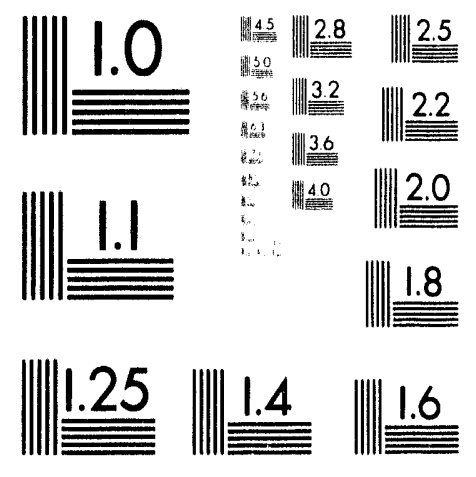



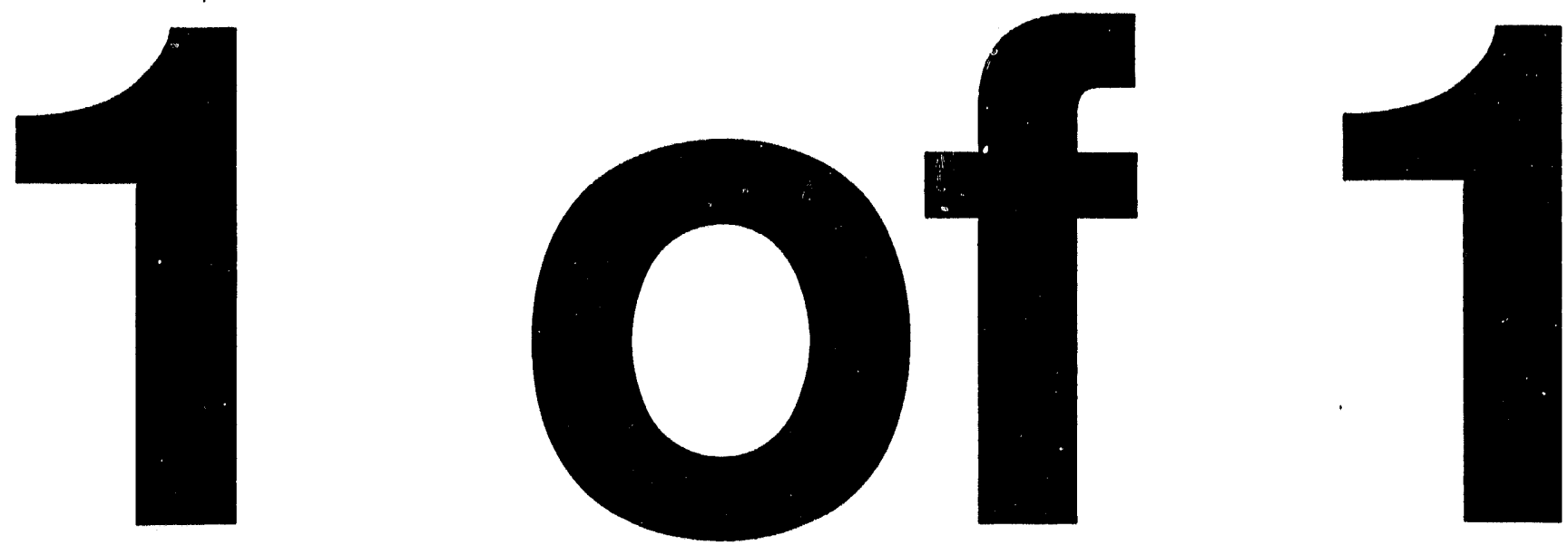
Interpretation of the Results of the CORA-33

Dry Core BWR Test

\author{
L. J. Ott"
}

Oak Ridge National Laboratory (ORNL)

Oak Ridge, Tennessee 37831

Siegfried Hagen

Kernforschungszentrum Karlsruhe (KfK)

7500 Karlsruhe 1, Federal Republic of Germany

\begin{abstract}
All BWR degraded core experiments performed prior to CORA-33 were conducted under "wet" core degradation conditions for which water remains within the core and continuous steaming feeds metal/steam oxidation reactions on the in-core metallic surfaces. However, one dominant set of accident scenarios would occur with reduced metal oxidation under "dry" core degradation conditions and, prior to CORA-33, this set had been neglected experimentally.
\end{abstract}

The CORA-33 experiment was designed specifically to address this dominant set of BWR "dry" core severe accident scenarios and to partially resolve phenomenological uncertainties concerning the behavior of relocating metallic melts draining into the lower regions of a "dry" BWR core [the ex-reactor experiments at Sandia National Laboratories (SNL) will further address these uncertainties]. CORA-33 was conducted on October 1, 1992, in the CORA test facility at KfK. Review of the CORA-33 data indicates that the test objectives were achieved; that is, core degradation occurred at a core heatup rate (characterized by the absence of any temperature escalation due to oxidation) and a test section axial temperature profile (at incipient structural melting) that are prototypic of full-core nuclear power plant (NPP) simulations at "dry" core conditions.

Simulations of the CORA-33 test at ORNL have required modification of existing control blade/canister materials interaction models to include the eutectic melting of the stainless steel/Zircaloy interaction products and the heat of mixing of stainless steel and Zircaloy. The timing and location of canister failure and melt intrusion into the fuel assembly appear to be adequately simulated by the ORNL models.

This paper will present the results of the posttest analyses carried out at ORNL based upon the experimental data and the posttest examination of the test bundle at KfK. The implicaticns of these results with respect to degraded core modeling and the associated safety issues are also discussed.

- Research sponsored by the Office of Nuclear Regulatory Research, U.S. Nuclear Regulatory Commission under Interagency Agreement No. 1886-8136-6L with the U.S. Department of Energy under contract DE-AC05-84OR21400 with Martin Marietta Energy Systems, Inc.
"The submitted manuscript has been authored by a contractor of the U.S. Government under contract No. DE-AC05-84OR21400. Accordingly, the U.S. Government retains a nonexclusive, royalty-free license to publish or reproduce the published form of this contribution, or allow others to do so, for U.S. Government purposes."

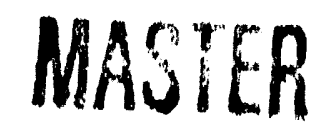

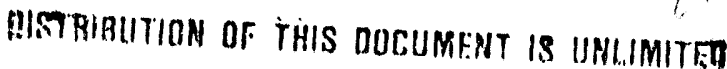




\section{INTRODUCTION}

Review of the results of probabilistic risk assessment (PRA) demonstrates conclusively that the BWR is vulnerable only to loss of reactor vessel injection, and that the postulated accident sequence scenarios leading to core damage always involve means of failure of function of the vessel injection systems. As defined, the various severe accident sequences involve different pathways to and timing of loss of vessel injection capability but, in every case, the core must become uncovered before core damage can occur.

The Station Blackout accident sequence has consistently been identified as the leading contributor to the calculated core damage frequency in recent PRAs for plants of the BWR design. Station Blackout is the accident sequence initiated by loss of off-site power and the associated scram and closure of the main steam isolation valves combined with failure of the station diesels (or gas turbines) to start and load. Therefore, all electric motor-driven reactor injection systems become unavailable at the inception of the accident sequence. In general, BWRs are well protected aguinst core damage because they have redundant reactor vessel injection systems to keep the core covered with water. The reason that Station Blackout is the leading contributor to BWR core damage frequency is simply that the majority of the reactor vessel injection systems are dependent upon the availability of alternating current (AC) power and BWRs are vulnerable to loss of injection.

Most of the 37 operating BWR facilities in the United States are protected against loss of the motor-driven reactor vessel injection systems by having steam turbine-driven injection systems. Since these systems rely upon direct current (DC) power for valve operation and turbine governor control, they will eventually be lost if $\mathrm{AC}$ power is not restored before the unit batteries become exhausted. The accident sequence involving temporary successful operation of the turbine-Jriven injection systems is classified as Long-Term Station Blackout because a significant period of time (typically six to eight hours) would elapse before battery exhaustion caused loss of reactor vessel injection capability and means for operator control of pressure. The characteristics of this sequence are (1) loss of injection, (2) vessel depressurization by the operator, (3) loss of ability to manipulate the safety relief valves (SRVs) after battery failure, (4) vessel pressure dependent on SRV automatic actuations, (5) boiloff, and (6) core steaming dominated by SRV actuations. This sequence is termed a "wet" core degradation scenario; that is, during the core degradation process there is water within the core with continuous steaming that can feed metal/steam oxidation reactions.

The second form of the severe accident sequence associated with loss of all AC power is termed Short-Term Station Blackout (STSB) because for this sequence, the steam turbine-driven injection systems fail to start upon demand. However, DC power is available for SRV actuation during the period of core degradation so that the operators can take meaningful action in following the Emergency Procedure Guidelines (EPGs).

The basic functional goal of the EPGs is to establish the prudent actions to be taken by the operators in response to the symptoms observed by them at any point in time. Once entry into the EPGs has occurred, the operators are expected to take the specified actions regardless of equipment design bases limitations or licensing commitments. The guidelines use multiple mitigation strategies wherever possible so that recovery from an abnormal situation does not require successful operation of any one system or component. 
In the STSB scenario, if AC power is not restored, partial uncovering of the core will occur and, per the EPGs, the operators will initiate the "steam cooling" maneuver. The purpose of this maneuver is to delay fuel heatup by cooling the uncovered upper regions of the core by a rapid flow of steam. Since the source of the steam is the remaining inventory of water in the reactor vessel, however, the steam cooling maneuver provides only a temporary delay ( 20 to 30 minutes) in core heatup and concludes with a vessel water level below the core plate. (The core plate is located $\sim 23 \mathrm{~cm}$ below the active fissile region of the core.) The characteristics of this sequence are (1) no injection, (2) vessel depressurized, (3) boiloff with flashing during depressurization, and (4) steam-starved core degradation. This sequence is termed a "dry" core degradation scenario because core degradation occurs under minimal steaming conditions with essentially a stagnant, steam-starved core atmosphere.

Previously, all BWR severe fuel damage experiments have been conducted under "wet" core conditions. Thus, one dominant set of accident scenarios, the "dry" core sequences, has been entirely neglected experimentally. Therefore, the USNRC requested the CORA staff to conduct a "dry" core experiment in the CORA facility.

The CORA facility at Kernforschungszentrum Karlsruhe (KfK) was especially designed for the severe fuel damage (SFD) experiments, and the facility simulates the decay heat of the fuel rods by electrical heating using central tungsten heaters. A schematic view of the CORA facility ${ }^{1}$ and an enlarged presentation of a BWR bundle inside the high-temperature shield are given in Figure 1. The fuel rod bundle, which is the central part of the facility, is enclosed in a 1-mm thick Zircaloy shroud, covered by $2 \mathrm{~cm}$ of $\mathrm{ZrO}_{2}$ fiher insulation. This arrangement is surrounded during the test by the high-temperature shield, which can be lowered into the lower part of the facility (quench unit) for mounting and posttest inspection of the bundle. The quench unit also contains the water-filled quench cylinder, which can be raised around the bundle hydraulically at a controlled speed. Superheated steam and argon are introduced at the lower end of the bundle.

The CORA facility has the capability to study large, long fuel rod bundles (up to 57 fuel rods, $2 \mathrm{~m}$ in length). During the test, the damage progression in the bundle at selected elevations is registered by video systems and $35-\mathrm{mm}$ still cameras. After the test, the bundle can be inspected and photographed without mechanical handling of the bundle.

The CORA experimental test matrix is given in Table 1. Tests for the investigation of the behavior of PWR fuel elements, as well as of BWR fuel elements, are included in the matrix.

Six BWR experiments have been conducted in the CORA facility since 1988. An overview of these experiments (test completion date, test objective, and a brief summary of the test results) is listed in Table 2.

\section{CORA-33 PRETEST CALCULATIONS}

In an effort to better characterize the initial and boundary conditions for the CORA-33 dry core experiment and the SNL ex-reactor experiments, a study of the typical dominant BWR accident sequence occurring under dry core conditions was completed at ORNL. Given the availability of detailed data on the relative power distribution in the Susquehanna Unit 1, Cycle 3 core, the Susquehanna plant was used as the model RWR facility. The core power distribution is similar to that of Biowns Ferry, which has been used as the model plant in previous ORNL severe accident analyses, and is considered representative of the distributions produced by the U.S. 
BWR core fuel loading arrangements. The accident scenario studied is the STSB sequence with automatic depressurization system (ADS) actuation per operator adherence to the EPG guidelines. This sequence involves dry core degradation and material relocation, which is typical of all dominant hypothetical U.S. BWR accident sequences with the single exception of LongTerm Station Blackout.

The primary variables from the ORNL station blackout study that have been used to formulate the desired experimental boundary conditions for CORA-33 are (1) the core heatup rate (0.3$0.5 \mathrm{~K} / \mathrm{s}),(2)$ the core axial temperature profile at incipient control blade liquefaction, and (3) the water evaporation rate from the vessel lower plenum [the only (and very small) steam source to the lower core region].

The primary CORA experimental variables that can be manipulated to achieve the desired dry core degradation conditions are (1) the test section electrical power input and (2) the composition and flow rate of the gas stream entering the test section.

Given the previous experience gained in analyzing the CORA-31 BWR test, ${ }^{2}$ it was known that a core heatup of $0.3-0.5 \mathrm{~K} / \mathrm{s}$ would be achieved using the CORA-31 electrical power input. Subsequent simulations indicated that the predicted test section heatup rate and evaporation rates from the CORA quench tank were consistent with the STSB accident sequence.

Since representation of steam-starved conditions in the core region was a primary purpose of this test, it would have been preferable to have no additional gas flow entering the test section. However, the experimental bundle is warmed initially by argon, which is electrically heated prior to entering the test section; and to avoid damage to the heater, gas flow through the device must be maintained. Normally, for BWR experiments in CORA, the argon flow through the heater and test section is maintained at $\sim 8 \mathrm{~g} / \mathrm{s}$ for the preheat, transient, and cooldown phases of the experiment, and $\sim 2 \mathrm{~g} / \mathrm{s}$ of water is vaporized and superheated along with the argon during the transient phase. To achieve the purpose of CORA-33, no water was added, and after preheating the bundle with argon at $8 \mathrm{~g} / \mathrm{s}$, the argon flow was reduced to the minimum $(3 \mathrm{~g} / \mathrm{s}) \mathrm{recommended}$ by the heater manufacturer for the transient phase of the experiment.

The final CORA-33 pretest simulations predicted a bundle axial temperature profile (Figure 2) at incipient control blade liquefaction consistent in shape with the profile predicted for the lower one-meter section by the Susquehanna STSB calculations. However, as shown in Figure 2, the predicted lower test section temperatures $(<40 \mathrm{~cm})$ are somewhat lower than the actual values for the Susquehanna STSB sequence as calculated from plant data.

\section{METHOD OF POSTTEST ANALYSIS}

An important part of the Boiling Water Reactor Core Melt Progression Phenomena Program (BWRCMP) activity at ORNL is the interpretation and use of the results of the CORA BWR tests. The ORNL BWR experiment-specific CORA models 3,4 have been used both in Germany and in the U.S. in pretest analyses for experimental design and operating conditions, and in posttest analyses for interpretation of the experimental results. To date, the CORA/BWR models have provided far more precise predictions $2,5-8$ of the conditions in the BWR experiments in CORA than have previously been available. This has provided a basis for more accurate and more complete interpretation of the phenomena for which the experiments are performed. Many of the phenomena under investigation in the BWR experiments in CORA are currently modeled 
only roughly, if at all, in the MELCOR ${ }^{9}$ and the SCDAP/RELAP5 ${ }^{10}$ whole-core accident analysis codes.

The CORA/BWR experiment-specific models are designed to predict the heat transfer rates, steaming rates, fluid flow, chemical reaction rates, and the temperatures in the test section during CORA BWR experiments. The heat transfer processes include conduction in solid structures, convection and boiling in the liquid phase, convection and radiation in the gas phase, and radiation between the interacting surfaces. Metal/water reaction kinetics are incorporated to determine the reaction rates of steam with Zircaloy in the rods, canister and shroud liner; with stainless steel in the control bladc sheath; and with $\mathrm{B}_{4} \mathrm{C}$ absorber in the control blade interior. From the metal/water reactions, calculations derive the hydrogen generation rate and the temporal and spatial distribution of oxide formations. These models are thus able to produce estimates of the temperature history of the test assembly as well as clad oxidation, hydrogen generation, and the extent of melting and relocation of assembly components.

The experiment-specific models supplement and support the systems-level accident analysis codes. They allow the analyst to accurately quantify the observed experimental phenomena and to reduce the effect of known uncertainties. They provide a basis for the efficient development of new models for phenomena that are currently not represented (such as material interactions). They can provide validated phenomenological models (from the results of the experiments) that may be incorporated in the systems-level "whole-core" codes.

For the posttest analyses, measured information can supply the initial spatial temperature profile in the test section, and boundary conditions can be specified by the measured electric power, test section pressure, and inlet coolant conditions. Thus, the CORA/BWR models provide a solution to this initial/boundary value problem, and this solution may be assessed by comparing calculated and measured core structural thermal responses.

\section{CORA-33 POSTTEST ANALYTICAL SIMULATION RESULTS}

\subsection{OVERVIEW}

CORA-33 is the first BWR experiment conducted in the CORA facility with no direct steam feed to the test section. This is in line with the basic purpose of this experiment, which is to observe and record the core degradation phenomena of prototypic BWR core structures subjected to dry core accident conditions. After the transient, the bundle was slow-cooled via flow of the argon purge gas.

A synopsis of the significant events and timing that occur in the CORA-33 test simulation is included in Table 3. The simulation results extend from $2940 \mathrm{~s}(60 \mathrm{~s}$ before the initial power increase) to $9000 \mathrm{~s}$ (700 s after power termination).

Since there was no direct steam feed to the test section in this test, no temperature escalation due to Zircaloy/steam chemical reaction occurred. Water from the quench tank (that cools the lower end of the electrically heated rods) did evaporate, and this small amount of steam was consumed in the test section. The peak evaporation rate during powered operation was $\sim 270 \mathrm{mg} / \mathrm{s}$; this is about ten percent of the direct steam feed of $\sim 2 \mathrm{~g} / \mathrm{s}$ that has been employed in prior CORA BWR 
experiments. A comparison of the experimental and calculated hydrogen generation rate is presented in Figure 3. A plot of the total hydrogen generated (versus time) is given in Figure 4.

In general, the CORA/BWR experiment-specific model simulation of CORA-33 provides calculated results for the core, shroud, and high temperature shield structural thermal responses that compare very well with the experimental data (see Figures 5-16).

Through the period of intact geometry (before $\sim 5000 \mathrm{~s}$, see Table 3 for a synopsis of the significant events and timing in the CORA-33 test simulation) there is excellent agreement between the calculated and observed structural thermal response for the entire test section (see Figures 5-16). After $\sim 5100 \mathrm{~s}$, the response of the lower test section is driven predominantly by relocating melt from the upper portion of the test section (the calculations then tend to be less precise).

Above the $450-\mathrm{mm}$ plane, there are no apparent responses to relocating melt, basically because at incipient control blade liquefaction (at $\sim 904 \mathrm{~s}$ ), the structural heatup between $450-975 \mathrm{~mm}$ is reasonably uniform (the cladding temperature at these levels ranges from 1175 to $1300^{\circ} \mathrm{C}$ )-this was predicted in the pretest calculations. The calculated response of the structures at the planes below $450 \mathrm{~mm}$ agrees reasonably well with the experimental data. The CORA/BWR relocation/freezing/remelting models appear to adequately reflect this experimental phenomena.

After $\sim 5100 \mathrm{~s}$, the lower core $(-54 \mathrm{~mm}$ to $350 \mathrm{~mm})$ exhibits a periodic behavior of melt freezing, remelting, relocating, and refreezing. This continues lower and lower into the test section, as long as electrical power is applied. After electrical power is terminated, the end-state of the core is set. A comparison of the calculated and measured end-state condition of the test section is presented in Figure 17.

The calculated end-state (at $9000 \mathrm{~s}$ ) is binodal with a Zircaloy blockage (primarily clad and shroud liner) between $75-225 \mathrm{~mm}$ and a Zircaloy (from the canister)/stainless steel (from the control blade) blockage from -200 to $25 \mathrm{~mm}$. The experimental methods of measuring the posttest blockage do not reflect the presence of blockages below $0 \mathrm{~mm}$; however, a significant blockage was observed at the steam inlet $(\sim-50$ to $0 \mathrm{~mm})$ in the posttest examination of the bundle. ${ }^{11,12}$

After $\sim 7000 \mathrm{~s}$, the calculated power distribution within the test section is less certain and computed values for the bundle voltage, current and electrical resistance tend to deviate from the experimental values. As discussed in Reference 6, at the high temperatures present in these severe fuel damage experiments, electrical shunting in the fuel pellets surrounding the heating element becomes important. Also, referring to Table 3, by 7000 s clad melting and relocation had progressed for $\sim 400 \mathrm{~s}$ during the experiment and the presence of molten metallics around the fuel pellets and heating element also affected the power distribution. This leads to increased uncertainty in the computed local (nodal) power generation and, therefore, increased uncertainty in the computed structural temperatures after $7000 \mathrm{~s}$. The late phase (i.e., after $7000 \mathrm{~s}$ ) computed structural temperatures are higher than observed and can lead to predictions of further material relocation than would have otherwise occurred. The computed test section blockage at $7000 \mathrm{~s}$ (see Figure 17) very closely matches the KfK measured end-state blockage.

Given this discussion with respect to late-phase uncertainties, it should be obvious (referring to Table 3 and Figure 17) that most of the test section destruction had already occurred by experiment time $7000 \mathrm{~s}$. The last $1300 \mathrm{~s}$ of powered operation simply cooked the test section 
and only resulted in moving the blockages another 50 to $150 \mathrm{~mm}$ lower within the test bundle apparatus. This test, which is based upon a prototypic axial thermal gradient, resulted in more material moving lower in the test section (even past the bottom of the active heated zone) than has been previously observed.

The following Section provides the chronology of the simulation results with respect to structural oxidation, melting, interaction, relocation, and refreezing.

\subsection{DISCUSSION}

Electrical power was initiated at $3000 \mathrm{~s}$ and, over the period of $3500-4500 \mathrm{~s}$, the average heatup rate (for the heated rods) was $0.29-0.44 \mathrm{~K} / \mathrm{s}$ for elevations above the thermal/hydraulic entrance zone $(\leq 300 \mathrm{~mm})$. By $\sim 4500 \mathrm{~s}$, the bundle attained a temperature profile peaked between $700-$ $800 \mathrm{~mm}$; generally, this profile was maintained for the remainder of the test.

Hydrogen generation was observed by the experimental detection apparatus as early as $3500 \mathrm{~s}$. During power operation, the quench tank water surrounding the lower ends of the electric fuel rod simulators increased in temperature from $62^{\circ} \mathrm{C}$ to $102^{\circ} \mathrm{C}$, and there was mass loss from the tank due to evaporation.

By $4904 \mathrm{~s}$, significant Zircaloy oxidation had occurred ( $3.2 \mathrm{~g}$ of hydrogen generated and $\sim 0.5 \%$ fraction clad reacted) and the control blade stainless steel/ $\mathrm{B}_{4} \mathrm{C}$ structure had reached its liquefaction temperature of $\sim 1232^{\circ} \mathrm{C}$ between the $675-825-\mathrm{mm}$ elevations. About $350 \mathrm{~mm}$ of the adjacent blade length was within $40^{\circ} \mathrm{C}$ of the liquefaction temperature at this time.

In the CORA-33 test, a differential pressure across the cladding of 2.2-3 bar was maintained until cladding failure; experimentally, six rods were instrumented and were observed to fail between 4854 and $5165 \mathrm{~s}$. Concurrent cladding strain and oxidation in the Zircaloy $B$ phase occurred and the computed clad failure times (due to strain) ranged between 4940 and $5012 \mathrm{~s}$. Given the uniform upper core temperatures (at $5100 \mathrm{~s}$ between 525 and $925 \mathrm{~mm}$, the clad temperature was $1367^{\circ} \mathrm{C} \pm 20^{\circ} \mathrm{C}$ ) the computed cladding strain was significant over $400 \mathrm{~mm}$ of the rod length.

Liquefaction of the control blade is predicted to begin at $\sim 4904 \mathrm{~s}$ between axial levels $675-$ $825 \mathrm{~mm}$. By $5100 \mathrm{~s}$, the liquefaction front is predicted to extend from 375 to $975 \mathrm{~mm}$ with frozen relocated material reaching downward to $275 \mathrm{~mm}$. A blockage (only the tip section of the interstitial region was not blocked) between the control blade and the canister is predicted to have formed at this time between axial levels $325-375 \mathrm{~mm}$ with rapid stainless steel/Zircaloy chemical interaction occurring over this blockage span.

The canister breached at $\sim 5230 \mathrm{~s}$ and molten Zircaloy/stainless steel eutectic began flowing down the inside of the canister wall. By $5280 \mathrm{~s}, \sim 200 \mathrm{~mm}$ of the canister wall had eroded, the flow channel adjacent to the canister had blocked, and molten eutectic was diverted laterally into the first row of fuel rods.

By $5460 \mathrm{~s}$, the flow channels around the rods adjacent to the canister wall had become blocked between 75-125 mm. At this time, $350 \mathrm{~mm}$ (between 575 and $925 \mathrm{~mm}$ ) of the control blade had completely liquefied and melting was underway between $325-1035 \mathrm{~mm}$. Fuel rod temperatures were less than $1600^{\circ} \mathrm{C}$ and $\sim 7 \mathrm{~g}$ of hydrogen had been generated. 
At $5580 \mathrm{~s}$, complete control blade liquefaction extended from $475-975 \mathrm{~mm}$ (i.e., $50 \%$ of the control blade in the active heated length from $0-1(10) \mathrm{mm}$ ).

By $5730 \mathrm{~s}$, eutectic material, which had frozen around the fuel rods earlier, had reheated to its melting point and began to relocate lower into the test section. The cladding temperature reached $1700^{\circ} \mathrm{C}$ between $675-875 \mathrm{~mm}$ at $5820 \mathrm{~s}$. At this time, $200-300 \mathrm{~mm}$ of the canister (below $475 \mathrm{~mm}$ ) had been dissolved and $\sim 700 \mathrm{~mm}$ of the control blade had liquefied. Also, there were significant local blockages in the region between 75 and $325 \mathrm{~mm}$.

When the Zircaloy cladding began to melt at $6616 \mathrm{~s}$, substantial damage to the test section had already occurred. At that time, no portion of the control blade remained between $175-1143 \mathrm{~mm}$ and $250-300 \mathrm{~mm}$ of the canister wall had liquefied and relocated. Zircaloy/stainless steel eutectic had penetrated the fuel assembly to the second row of rods and coated the first row between -100 and $125 \mathrm{~mm}$.

The canister began to melt between $675-825 \mathrm{~mm}$ at $\sim 6774 \mathrm{~s}$ and the Zircaloy shroud liner began melting at $6960 \mathrm{~s}$.

By $7000 \mathrm{~s}$, the bundle had rearhed the state depicted in Figure 17. The fuel rods had been declad (except for $\mathrm{ZrO}_{2}$ remnants) between $425-925 \mathrm{~mm}$, the canister was in the process of melting over the $425-925-\mathrm{mm}$ range, the top of the control blade is at $175 \mathrm{~mm}$, and some control blade melting is occurring between $1143-1214 \mathrm{~mm}$. The relocated mass was essentially binodal: clad relocation was concentrated between $125-425 \mathrm{~mm}$, and the canister/stainless steel mass is lumped between -150 and $75 \mathrm{~mm}$ in the fuel assembly. Around the control blade, refrozen material exists between $0-175 \mathrm{~mm}$.

The peak electrical power of $22.4 \mathrm{~kW}$ was attained at experiment time $8015 \mathrm{~s}$ and was maintained at that level until $8300 \mathrm{~s}$ when the powered operation of the experiment was terminated. Argon test section flow was increased at $8330 \mathrm{~s}$ to begin the cooldown phase of the test.

After $7000 \mathrm{~s}$, and for the remaining $1300 \mathrm{~s}$ of the transient, little bundle reconfiguration occurred. The blockages present at $7000 \mathrm{~s}$ gradually moved lower in the bundle (by $50-150 \mathrm{~mm}$ ) until power was terminated at $8300 \mathrm{~s}$.

\subsection{SIGNIFICANT OBSERVATIONS}

\subsubsection{Hydrogen Generation}

Comparisons of the hydrogen generation rate and the integrated hydrogen mass generated for the CORA-33 experiment are presented in Figures 3 and 4.

Another method of studying the hydrogen generation is to break down the evolution into event intervals (that is, for example, how much hydrogen evolves between the start of the experiment and incipient control blade melting). Table 4 presents the hydrogen evolved in six different intervals in the CORA-33 experiment. These arbitrary intervals can be condensed into two logical intervals: (1) intact cladding (through incipient melting) and (2) the period after initial 
clad melting (melting/relocation and formation of blockages). These results together with the CORA-28 analysis are presented in Table 5.

Surprisingly, only $\sim 25 \%$ of the hydrogen generated in these experiments occurs during the "intact cladding" phase. Over $75 \%$ of the total hydrogen evolution occurred during the relocation/blockage period of these experiments.

All integrated codes compute hydrogen generation in intact geometry reasonably well, but handle the later phase (post-intact-cladding) of an experiment (or accident scenario) less robustly. In general, severe accident analysis codes should be judged on their ability to predict hydrogen generation on the following merits: (1) rate of generation, (2) total hydrogen generated, and (3) ratio of intact/degraded hydrogen production. Obviously, these codes must be capable of accurately estimating the metal-steam reaction rate during the period of clad degradation and blockage formation since the majority of the hydrogen generation has been demonstrated (Table 5) to occur during this time frame.

\subsubsection{Blockage/Interaction Modeling}

A conceptualization of the ORNL canister/control blade materials interaction, relocation/blockage models 13,14 is outlined in Figure 18. This figure comprises six subfigures $(a-f)$, which visually describe the progressive steps in the structural liquefaction/dissolution, blockage, and subsequent structural failure for the BWR control blade and canister models. The failure process begins with the $\mathrm{B}_{4} \mathrm{C} /$ stainless steel reaction in the control blade absorber tubes (Figure 18b). Eventually, this material liquefies $\left(\sim 1232^{\circ} \mathrm{C}\right)$, Figure $18 \mathrm{c}$; and then, by either failing the control blade sheath or flowing through perforations in the sheath, relocates downward leaving a crust (frozen relocated eutectic) on the surface of the control blade (Figure 18d). This crust builds up (Figure 18e) until a blockage occurs, at which time the interaction between the relocated stainless steel/ $\mathrm{B}_{4} \mathrm{C}$ and the Zircaloy canister wall begins. The canister finally fails (due to the material interaction), Figure 18f, allowing flow into the fuel assembly and down the inside of the canister wall.

In the CORA-31 analyses, ${ }^{2}$ the failure of the canister wall due to the stainless steel/Zircaloy interaction was predicted to occur too late. The phase of the model that acted too slowly was the actual breach (occurring between the times represented by Figures $18 \mathrm{e}$ and $\mathrm{f}$ ) of the canister wall. This delay was not apparent in the CORA-16 and CORA-17 posttest analyses ${ }^{6}$ with their high initial and oxidation heatup rates; but in CORA-31, ${ }^{2}$ with a heatup rate of $0.3 \mathrm{~K} / \mathrm{s}$, the breaching process was prolonged and did not agree with the experimental observations at the 350- and 450-mm elevations. Preliminary analyses of the CORA-33 experiment also illustrated similar disagreement in the calculated and observed responses of the lower core.

The stainless steel/Zircaloy interaction phase (Figure $18 \mathrm{e}$ ) is governed by Hofmann's 15 kinetics, and the canister normally is fully reacted with the stainless steel/ $\mathrm{B}_{4} \mathrm{C}$ interior blockage at a temperature below the stainless steel/Zircaloy liquefaction temperature $\left(\sim 1250^{\circ} \mathrm{C}\right)$. In the original control blade/canister models, ${ }^{13,14}$ breach of the canister (between Figures $18 \mathrm{e}$ and $\mathrm{f}$ ) essentially occurs via melting of the structure at the liquefaction temperature $\left(\sim 1250^{\circ} \mathrm{C}\right)$. This meltout is governed by (1) the heat input from the fuel assembly (radiant, convective, and oxidation energies), and (2) the energy required for the phase change (i.e., the heat of fusion). 
Hofmann 15 states that the liquefaction occurs very quickly at $1250^{\circ} \mathrm{C}$ in his separate-effects studies.

Dr. Dana Powers of SNL 16 indicated that new German studies ${ }^{17}$ of the Fe-Ni-Zr metallic system showed that in the dissolution process there can be rigorous localized exothermic heat generation. Also, these $\mathrm{Fe}-\mathrm{Ni}-\mathrm{Zr}$ interaction products liquefy at low temperature $\left(\sim 950^{\circ} \mathrm{C}\right.$, from the binary-phase diagrams), and these interaction products exhibit lowered (as compared to Zircaloy or stainless steel) heats of fusion. ${ }^{16}$

Therefore, the following modifications to the control blade/canister interaction/melting models have been recently implemented.

1) addition of the heat of mixing of $\mathrm{Zr} /$ stainless steel,

2) allowance for low temperature melting of the $\mathrm{Zr} /$ stainless steel interaction products, and

3) allowance for reduction of the heat of fusion of these interaction products.

The result of these modifications are illustrated in Figure 19 at the 200 -mm level. The computed initial failure times closely match the data (inferred from the canister thermal response) and the overall response of the lower core $(<450 \mathrm{~mm})$ to relocating melt agrees well with the experimental data.

Also, analysis ${ }^{8}$ of the CORA-28 test (employing a $1 \mathrm{~K} / \mathrm{s}$ heatup rate and $2 \mathrm{~g} / \mathrm{s}$ steam feed) indicates that these modified control blade/canister models are performing well under vastly different test conditions (i.e., from CORA-33).

\subsubsection{Melt Relocation}

As noted in Sections 4.1 and 4.2, more melt relocated further (i.e., lower) into the test section (even below the active heated length, see Figure 20) than has been observed in any previous CORA BWR test. The axial thermal gradient at incipient control blade liquefaction was near prototypic (Section 2); however, it was still slightly less steep (lower local temperatures) than the desired Susquehanna axial thermal gradient (Figure 2).

The results of CORA-33 indicate that for BWR dry core accident scenarios, substantial melt relocation onto the BWR core plate should be expected; it follows that integrated code models for the core plate should be developed that are capable of predicting the thermal response and associated failure of the core plate due to high temperature and loading.

The ex-reactor (XR) experiments at SNL (initial test conducted July 23, 1993) are intended to resolve phenomenological uncertainties concerning the behavior of relocating metallic melts draining into the lower regions of a dry BWR core as a result of a core-melt accident.

\subsubsection{Lateral Melt Intrusion into Fuel Assembly}

All degraded core BWR experiments (DF-4 and CORA) have demonstrated varying degrees of melt intrusion (stainless steel/Zircaloy) from the interstitial region of the core into the fuel rod 
assemblies within the individual channel boxes, see Figure 20. Models to allow melt intrusion into the channel box region and to represent the subsequent freezing/remelting/relocation of these melts within the fuel bundle have been added to the CORA/BWR experiment-specific conde. These models were employed in the analyses of CORA-33.

\subsubsection{Overall Degraded Core Modeling}

In general, the difference between a systems-level code calculation and an experiment-specific analysis of degraded core experiments is detail. The representation and solution of mass, momentum and energy balances are similar (if not the same). The models, correlations, constitutive relationships, physical properties are all, in general, identical. The difficulties that are encountered in applying a systems-level code to small-scale experiments are caused by experimental boundary and operating conditions that are significantly different from those representative of a full scale reactor core.

We do not mean to infer that the materials, structural spacing, gas flows, and heatup rates employed in the experiments are non-prototypic; care is taken to ensure that these are, to the maximum extent possible, prototypic. A simple example of what is meant derives from the fact that in small-scale high-temperature experiments, high radial heat losses will be encountered, which would not be the case for the same small structural portion if it were nestled within a fullscale reactor core. To adequately replicate (analytically) the heat transfer processes occurring during the experiment, significant detail (especially with respect to the radiant energy exchange) in the modeling is essential.

Ability to render the structural detail necessary for experimental analysis is not available in the systems-level codes and, probably, these codes should not be required to have this meticulousness.

The detailed experiment-specific inodels should be viewed for what they are - they are tools that allow the analyst to accurately quantify the observed experimental phenomena and to reduce the effect of known uncertainties. They also provide a basis (ergo, a platform) for the efficient development (and validation) of new tnodels for phenomena such as material interactions, that are not now modeled in the systems-level codes.

Currently, with the appropriate detail (as represented in the experiment-specific models), the observed results of the BWR degraded core experiments (DF-418, CORA-16 and CORA-17,6 CORA-31,2 CORA-33,7 and CORA-288) can be precisely predicted throughout the period of structural heatup, melt relocation, and metallic blockage formation.

The area of greatest modeling uncertainty, within the core, is the transition from the intact state (i.e., until incipient liquefaction) to the blocked state (where further axial melt relocation is inhibited). The CORA experiments provide the data base (via thermometry, video records, and precise end state bundle conditions) that allows validation and verification of models describing this transition period. The BWRCMP program has studied this transition phase of the degraded core accident and has improved the models to better reflect the phenomena observed in the CORA BWR experiments. These improved structural models for the BWR canister/control blade have been incorporated into the SCDAP/RELAP5 code; ${ }^{14}$ however, it is strongly recommended that these new SCDAP/RELAP5 component models be upgraded to include the 
recent enhancements (Section 4.3.2) developed as part of the CORA-28 and CORA-33 experiment-specific analyses.

\section{SUMMARY}

At the present state-of-the-art, with the appropriate level of detail, the degrading BWR core can be precisely modeled through structural failure/relocation and metallic blockage. Posttest analyses of the slow heatup CORA-33 dry core BWR experiment provides excellent agreement between the calculated bundle response and the experimental data.

The CORA-33 experiment is very important to advancing the understanding of BWR severe accident sequences because it is the first (and probably only) test to be conducted to examine core degradation phenomena under the dry, steam-starved conditions that would be expected to prevail for the U.S. BWR design.

Under dry core conditions with a nearly prototypic axial thermal gradient (at incipient control blade liquefaction), more melt relocated lower (even below the bottom of the active heated length) in CORA-33 than has been observed in any previous BWR test. This indicates that in BWR dry core accident scenarios, substantial melt relocation onto the BWR core plate should be expected and that integrated code models of the core plate (if they exist) must be capable of predicting the response and failure of the core plate due to this melt intrusion.

Posttest analyses of the CORA-33 BWR experiment has yielded additional insights that need to be considered in modeling the CORA experiments and/or degraded core phenomena:

1) Nearly $25 \%$ of the hydrogen generated in this test occurred while the cladding was intact. Over $75 \%$ of the total hydrogen evolved in the relocation/blockage phase of the experiment. This division of hydrogen generation was confirmed (also observed) in analyses of the CORA-28 test (a high heatup experiment under wet core conditions). The integrated codes must be capable of predicting the hydrogen generation during clad relocation and blockage formation since three times as much hydrogen is generated during this phase of the accident as compared to the amount generated during the earlier phase, while the cladding remains intact.

2) The ORNL control blade/canister models ${ }^{14}$ have had previous difficulties in calculating the canister failure (generally predicted to occur too late) in slow heatup $(\sim 0.3 \mathrm{~K} / \mathrm{s})$ experiments (CORA-312 and CORA-337). For the current analyses, these models have been modified to include

a) the addition of the heat of mixing of Zircaloy and stainless steel,

b) allowance for low temperature melting of the stainless steel/Zircaloy interaction products, and

c) allowance for the reduction of the heat of fusion for these products.

These modified models now closely predict the response (failure and thermal response) of the lower test section. Also, preliminary analyses of the CORA-28 test indicate that these models perform equally well under very different test conditions (i.e., from CORA-33). 
3) Models for the melt intrusion (observed in all BWR severe fuel damage experiments) into the rodded fuel assembly and the subsequent freezing/remelting/relocation of these melts have been developed and tested in the analyses of the CORA-33 experiment.

With a basic understanding of the relevant material interactions, the CORA video/thermometry recordings present a clear picture of the degradation process in a BWR core from the liquefaction of the control blade through the destruction of the Zircaloy channel wall to the dissolution of the Zircaloy cladding and fuel. The CORA experiments have provided the basic information on the processes of metallic melt relocation. The CORA BWR experiments provide the data base (via thermometry, video records and precise end state bundle characteristics), which will allow validation and verification of models that describe the phenomena occurring in the transition phase (from intact to blocked state) of a severe accident.

Transition-phase models have been tested in the experiment-specific analyses of the CORA BWR experiments and have been implemented at ORNL in the SCDAP/RELAP5 code for the BWR canister and control blade structures. It is strongly recommended that the SCDAP/RELAP5 BWR control blade/canister component models be upgraded to incorporate the recent enhancements developed as part of the CORA-28 and CORA-33 experiment-specific analyses.

\section{REFERENCES}

1. S. Hagen and K. Hain, "Out-of-Pile Bundle Experiments on Severe Fuel Damage; CORAProgram,” KfK 3677, 1986.

2. L. J. Ott, Posttest Analyses of the CORA-3I Slow Heatup BWR Experiment, letter report (ORNL/NRC/LTR-92/29) to Dr. A. Behbahani, Accident Evaluation Branch, Division of Systems Research, RES, USNRC, December 31, 1992.

3. L. J. Ott, Description of the CORA BWR Experiment-Specific Code, letter report (ORNL/NRC/LTR-90/23) to Dr. R. W. Wright, Accident Evaluation Branch, Division of Systems Research, RES, USNRC, September 30, 1990.

4. L. J. Ott, "Experiment-Specific Analyses in Support of Code Development," Eighteenth Water Reactor Safety Information Meeting, Rockville, Maryland, October 22, 1990.

5. L. J. Ott and W. I. van Rij, "In-Vessel Phenomena-CORA," Cooperative Severe Accident Research Program Semiannual Review Meeting, Bethesda, Maryland, May 8, 1991.

6. L. J. Ott, Posttest Analyses of the CORA-16 and CORA-17 BWR Experiments, letter report (ORNL/NRC/LTR-92i17) to Dr. A. Behbahani, Accident Evaluation Branch, Division of Systems Research, RES, USNRC, July 10, 1992.

7. L. J. Ott, Posttest Analysis of the CORA-33 Dry Core BWR Experiment, letter report (ORNL/NRC/LTR-93/21) to Dr. A. Behbahani, Accident Evaluation Branch, Division of Systems Research, RES, USNRC, August 31, 1993.

8. L. J. Ott, Posttest Analysis of the CORA-28 Preoxidized BWR Experiment, letter report (ORNL/NRC/LTR-93/26) to Dr. A. Behbahani, Accident Evaluation Branch, Division of Systems Research, RES, USNRC, September 30, 1993. 
9. R. M. Summers, R. K. Cole, et al., MELCOR 1.8.2: Computer Code Manual, Volume 1: Primer and Users' Guides, Sandia National Laboratories, February 1993.

10. C. M. Allison, E. C. Johnson, Editors, SCDAPIRELAP5/MOD2 Code Manual, Volumes I to III, NUREG/CR-5273, EGG-2555, September, 1989.

11. L. J. Ott, Report of Foreign Travel to KfK, FRG and Participation in the CORA-33 Experiment, letter report (ORNL/NRC/LTR-92/28) to Dr. A. Behbahani, Accident Evaluation Branch, Division of Systems Research, RES USNRC, November 20, 1992.

12. S. Hagen, et al., "First Results of CORA-Tests: -10, PWR with Culd Lower End; -33, Dry BWR," presented at the Cooperative Severe Accident Research Program Review Meeting, Bethesda, Maryland, May 5, 1993.

13. L. J. Ott, "ORNL Pre- and Post-Test Analyses of BWR Experiments at ORNL" presented at the International CORA Workshop 1992, Karlsruhe, FRG, October 6, 1992.

14. F. P. Griffin and K. A. Smith, BWR Control Blade/Channel Box Interaction and Melt Relocation Models for SCDAP-Revision 1, letter report (ORNL/NRC/LTR-92/12/R1) to Dr. Yi-Shung Chen, Accident Evaluation Branch, Division of Systems Research, RES, USNRC, December 31, 1992.

15. P. Hofmann et al., "Low-Temperature Liquefaction of LWR Core Comfonents," Severe Accident Research Program Partners Review Meeting, Brookhaven National Laboratory, Upton, New York, April 30- May 4, 1990.

16. Personal communication with Dr. Dana Powers of Sandia National Laboratories.

17. H. Wang, R. Lück, and B. Predel, "Thermodynamic Investigation on Liquid Iron-NickelZirconium Alloys," Journal of Phase Equilibria, 14, pp. 48-53, 1993.

18. L. J. Ott, Post-Test Analysis of the DF-4 BWR Experiment Using the BWRSARIDF-4 Code, letter report to Dr. R. W. Wright, Accident Evaluation Branch, Division of Systems Research, RES, USNRC, August 10, 1989.

\section{DISCLAIMER}

\footnotetext{
This report was prepared as an account of work sponsored by an agency of the United States This report was prepared an anted States Government nor any agency thereof, nor any of their employees, makes any warranty, express or implied, or assumes any legal liability or responsibility for the accuracy, completeness, or usefulness of any information, apparatus, product, or process disclosed, or represents that its use would not infringe privately owned rights. Reference herein to any specific commercial product, process, or service by trade name, trademark. manufacturer, or otherwise does not necessarily constitute or imply its endorsement, recom. manufacturer, or otherwise the United States Government or any agency thereof. The views and opinions of authors expressed herein do not necessarily state or reflect those of the United States Government or any agency thereof.
} 
Table 1. CORA Test Matrix in Chronological Order

\begin{tabular}{|c|c|c|c|c|}
\hline $\begin{array}{l}\text { Test } \\
\text { No. }\end{array}$ & $\begin{array}{c}\text { Max } \\
\text { Cladding } \\
\text { Temperatures }\end{array}$ & $\begin{array}{l}\text { Absorber } \\
\text { Material }\end{array}$ & $\begin{array}{l}\text { Other Test } \\
\text { Conditions }\end{array}$ & $\begin{array}{l}\text { Date of } \\
\text { Test }\end{array}$ \\
\hline 2 & $=2000^{\circ} \mathrm{C}$ & & $\mathrm{UO}_{2}$ reference, Inconel spacer & Aug. 6,1987 \\
\hline 3 & $\approx 2400^{\circ} \mathrm{C}$ & & $\mathrm{UO}_{2}$ reference, high temperature & Dec. 3, 1987 \\
\hline 5 & $\approx 2000^{\circ} \mathrm{C}$ & $\mathrm{Ag}, \mathrm{In}, \mathrm{Cd}$ & PWR absorber & Feb. 26, 1988 \\
\hline 12 & $\approx 2000^{\circ} \mathrm{C}$ & $\mathrm{Ag}, \operatorname{In}, \mathrm{Cd}$ & quenching & June 9,1988 \\
\hline 16 & $\approx 2000^{\circ} \mathrm{C}$ & $\mathrm{B}_{4} \mathrm{C}$ & BWR absorber & Nov. 24,1988 \\
\hline 15 & $\approx 2000^{\circ} \mathrm{C}$ & $\mathrm{Ag}$, In, Cd & rods with internal pressure & March 2,1989 \\
\hline 17 & $\approx 2000^{\circ} \mathrm{C}$ & $\mathrm{B}_{4} \mathrm{C}$ & (BWR) quenching & June 29,1989 \\
\hline 9 & $\approx 2000^{\circ} \mathrm{C}$ & $\mathrm{Ag}, \operatorname{In}, \mathrm{Cd}$ & 10 bar system pressure & Nov. 9,1989 \\
\hline 7 & $<2000^{\circ} \mathrm{C}$ & $\mathrm{Ag}, \operatorname{In}, \mathrm{Cd}$ & 57-rod bundle, slow cooling & Feb. 22, 1990 \\
\hline 18 & $<2000^{\circ} \mathrm{C}$ & $\mathrm{B}_{4} \mathrm{C}$ & (BWR) 48-rod bundle, slow cooling & June $2 \mathrm{i}, 1990$ \\
\hline 13 & $\approx 2200^{\circ} \mathrm{C}$ & $\mathrm{Ag}, \mathrm{In}, \mathrm{Cd}$ & $\begin{array}{c}\mathrm{OECD} / \mathrm{ISP} ; \text { quench initiation at } \\
\text { higher temperature }\end{array}$ & Nov. 25,1990 \\
\hline 29 & $\approx 2000^{\circ} \mathrm{C}$ & $\mathrm{Ag}$, In, Cd & preoxidized, quenching & April 11, 1991 \\
\hline 31 & $\approx 2000^{\circ} \mathrm{C}$ & $\mathrm{B}_{4} \mathrm{C}$ & (BWR) slow initial heatup $(\approx 0.3 \mathrm{~K} / \mathrm{s})$ & July 25,1991 \\
\hline 30 & $\approx 2000^{\circ} \mathrm{C}$ & $\mathrm{Ag}, \mathrm{In}, \mathrm{Cd}$ & slow initial heatup $(\approx 0.2 \mathrm{~K} / \mathrm{s})$ & Oct. 30, 1991 \\
\hline 28 & $\approx 2000^{\circ} \mathrm{C}$ & $\mathrm{B}_{4} \mathrm{C}$ & (BWR) preoxidized & Feb. 25, 1992 \\
\hline 10 & $\approx 2400^{\circ} \mathrm{C}$ & $\mathrm{Ag}, \mathrm{In}, \mathrm{Cd}$ & $\begin{array}{l}\text { reduced steam supply }(2 \mathrm{~g} / \mathrm{s}) \\
\text { lower end not insulated }\end{array}$ & July 16,1992 \\
\hline 33 & $\approx 2000^{\circ} \mathrm{C}$ & $\mathrm{B}_{4} \mathrm{C}$ & $\begin{array}{c}\text { (BWR) dry core conditions } \\
\text { no steam flow, heatup }(\sim 0.3 \mathrm{~K} / \mathrm{s})\end{array}$ & Oct. 1, 1992 \\
\hline W1 & $=2000^{\circ} \mathrm{C}$ & & $\begin{array}{c}\text { VVER-test } \\
\text { reference experiment }\end{array}$ & Feb. 18,1993 \\
\hline W2 & $=2000^{\circ} \mathrm{C}$ & $\mathrm{B}_{4} \mathrm{C}$ & VVER-test with absorber & April ?1,1993 \\
\hline
\end{tabular}

Initial heatup rate: $\approx 1.0 \mathrm{~K} / \mathrm{s}$; steam flow rate, PWR: $6 \mathrm{~g} / \mathrm{s}, \mathrm{BWR}: 2 \mathrm{~g} / \mathrm{s}$; quench rate (from the bottom) $\approx 1 \mathrm{~cm} / \mathrm{s}$. 


\section{Table 2. Overview of BWR Experiments Performed in the CORA Facility}

\begin{tabular}{|c|c|c|c|}
\hline Test Number & Date & Objective & Results \\
\hline CORA.16 & Nov. 24, 1988 & $\begin{array}{l}\text { Influence of } B_{4} C / S S \text { absorber } \\
\text { material on the Zircaloy channel box } \\
\text { walls, high heatup rate }(1 \mathrm{~K} / \mathrm{s})\end{array}$ & $\begin{array}{l}\text { Begin melting for the BWR bundle } \\
\text { by interaction between } \mathrm{B}_{4} \mathrm{C} \text { and } \\
\text { stainless steel at } 1200^{\circ} \mathrm{C} \\
\text { - Destruction of the channel box walls } \\
\text { by stainless steel/Zircaloy } \\
\text { interaction } \\
\text { - Distribution of the melt leads to } \\
\text { liquefaction of Zircaloy fuel rod } \\
\text { cladding and dissolution of } \mathrm{UO}_{2} \\
\text { pellets } \\
\text { - Relocation of melt to lower part of } \\
\text { bundle in absorber and fuel rod } \\
\text { region }\end{array}$ \\
\hline CORA-17 & June 29,1989 & $\begin{array}{l}\text { Additional damage progression } \\
\text { during quenching, high heatup rale } \\
(1 \mathrm{~K} / \mathrm{s})\end{array}$ & $\begin{array}{l}\text { Analogous behavior as in the PWR } \\
\text { test CORA-12 } \\
\text { - Fragmentation } \\
\text { - Preliminary strong temperature } \\
\text { increase before final cooldown } \\
\text { combined with a strong increase in } \\
\mathrm{H}_{2} \text { production }\end{array}$ \\
\hline CORA-18 & June 21,1990 & $\begin{array}{l}\text { Damage initiation in a larger bundle } \\
(48 \text { rods instead of } 18) \text {, high heatup } \\
\text { rate }(1 \mathrm{~K} / \mathrm{s})\end{array}$ & $\begin{array}{l}\text { Same general behavior as in small } \\
\text { bundle }\end{array}$ \\
\hline CORA-31 & July 25,1991 & $\begin{array}{l}\text { Influence of slow initial heatup }(0.3 \\
\mathrm{K} / \mathrm{s})\end{array}$ & $\begin{array}{l}\text { Same general damage behavior as in } \\
\text { the bundles heated at } 1 \mathrm{~K} / \mathrm{s} \\
\text { - increased materials interaction } \\
\text { - less relocation of melt } \\
\text { - axial temperature profile shifted up } \\
\text { by } \sim 100 \mathrm{~mm}\end{array}$ \\
\hline CORA-28 & Feb. 25,1992 & $\begin{array}{l}\text { Influence of pre-oxidation, high } \\
\text { heatup rate }(1 \mathrm{~K} / \mathrm{s})\end{array}$ & $\begin{array}{l}\text { different material behavior in upper } \\
\text { and lower parts of bundle } \\
\text { in the pre-oxidized upper bundle, } \\
\text { temperature escalation is delayed } \\
\text { and reduced } \\
\text { - pre-oxidation reduces materials } \\
\text { interaction } \\
\text { - reduced melt formation and } \\
\text { relocation } \\
\text { more of the } \mathrm{B}_{4} \mathrm{C} \text { absorber remains } \\
\text { than in previous tests }\end{array}$ \\
\hline CORA-33 & Oct. 1,1992 & $\begin{array}{l}\text { Influence of "dry" core atmosphere } \\
\text { (i.e., minimal steaming) with slow } \\
\text { initial heatup }(0.3 \mathrm{~K} / \mathrm{s}) \text {. }\end{array}$ & $\begin{array}{l}\text { no temperature escalation due to } \\
\text { limited steam input } \\
\text { melt relocated to much lower } \\
\text { elevations than in previous tests due } \\
\text { to the more prototypic axial } \\
\text { temperature profile }\end{array}$ \\
\hline
\end{tabular}


Table 3. Significant events predicted by the CORA-33 experiment-specific simulation

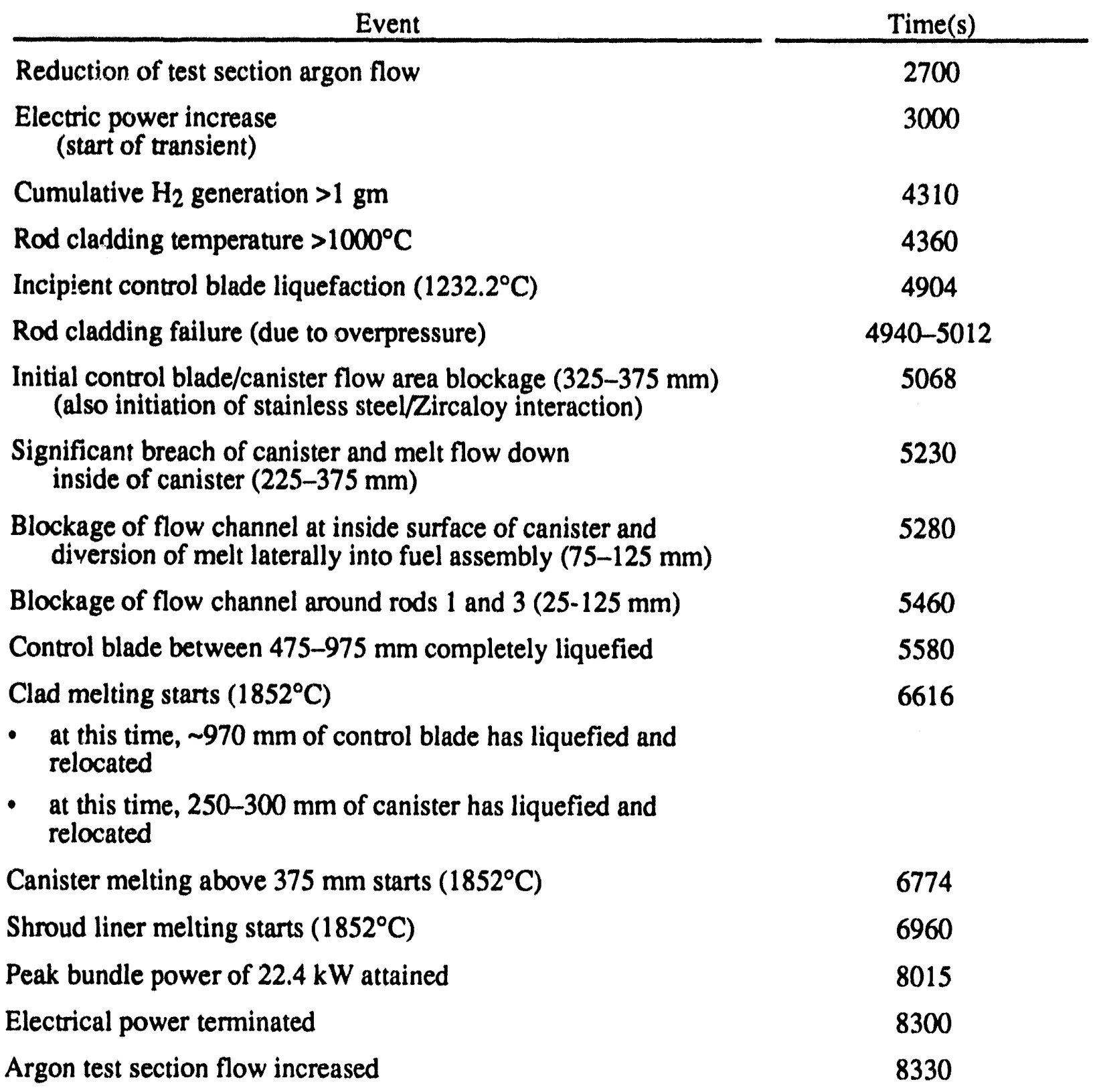


Table 4. CORA-33 hydrogen evolution phases"

\begin{tabular}{|c|c|c|}
\hline Event of Interval & Timing Interval (s) & $\begin{array}{c}\% \text { of Total Hydrogen } \\
\text { Generated }\end{array}$ \\
\hline $\begin{array}{l}\text { Start to incipient control } \\
\text { blade liquefaction } \\
\left(1232.2^{\circ} \mathrm{C}\right)\end{array}$ & $2940-4904$ & 4.2 \\
\hline $\begin{array}{l}\text { Incipient control blade } \\
\text { liquefaction to initial control } \\
\text { blade/canister blockage }\end{array}$ & $4904-5068$ & 1.3 \\
\hline $\begin{array}{l}\text { Initial blockage to lateral } \\
\text { movement of melt into fuel }\end{array}$ & $5068-5280$ & 1.9 \\
\hline $\begin{array}{l}\text { Melt movement into fuel to } \\
\text { initial clad melting }\left(1852^{\circ} \mathrm{C}\right)\end{array}$ & $5280-6616$ & 17.0 \\
\hline $\begin{array}{l}\text { Initial clad melting to } \\
\text { formation of stable } \\
\text { blockages }\end{array}$ & $6616-7000$ & 8.0 \\
\hline $\begin{array}{l}\text { Formation of stable } \\
\text { blockages to end of } \\
\text { experiment }\end{array}$ & $7000-10,000$ & 67.6 \\
\hline
\end{tabular}

Table 5. Hydrogen evolution phases

Event of Interval

\section{$-33$}

Intact cladding

(start to incipient melting)

Clad melt/relocation/blockage (incipient melting to end)

\section{CORA-28}

Intact cladding

$2940-4515$

24.6

Clad melt/relocation/blockage

$4515-10,000$ $\begin{array}{ll}2940-6616 & 24.4\end{array}$

$6616-10,000$

75.6
$\%$ of Total Hydrogen Generated

* at 10,000 s, a total of $78 \mathrm{~g}$ of hydrogen had been generated 


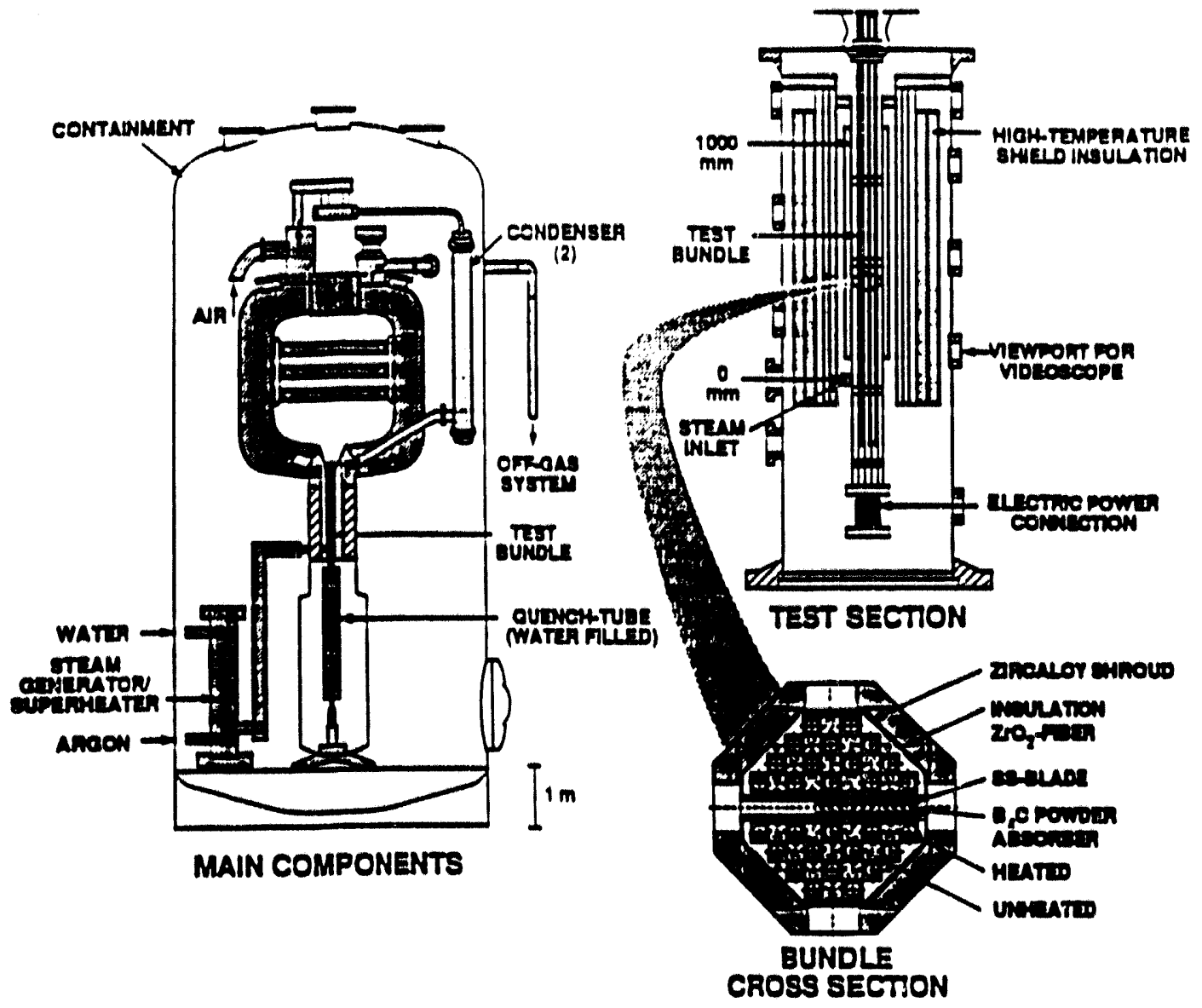

Figure 1. CORA severe fuel damage test facility and BWR bundle within high temperature shield.

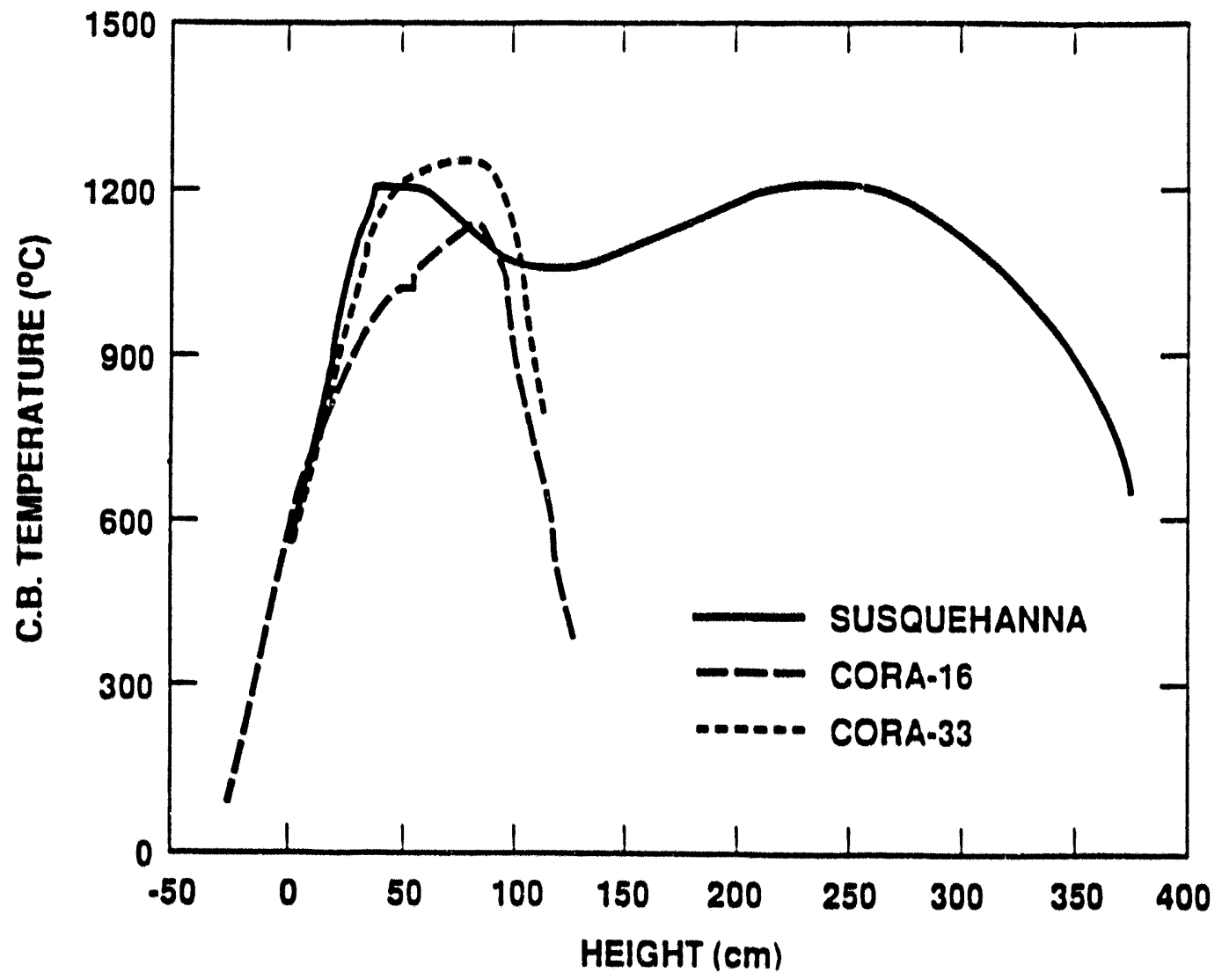

Figure 2. Axial temperature at incipient control blade liquefaction. 


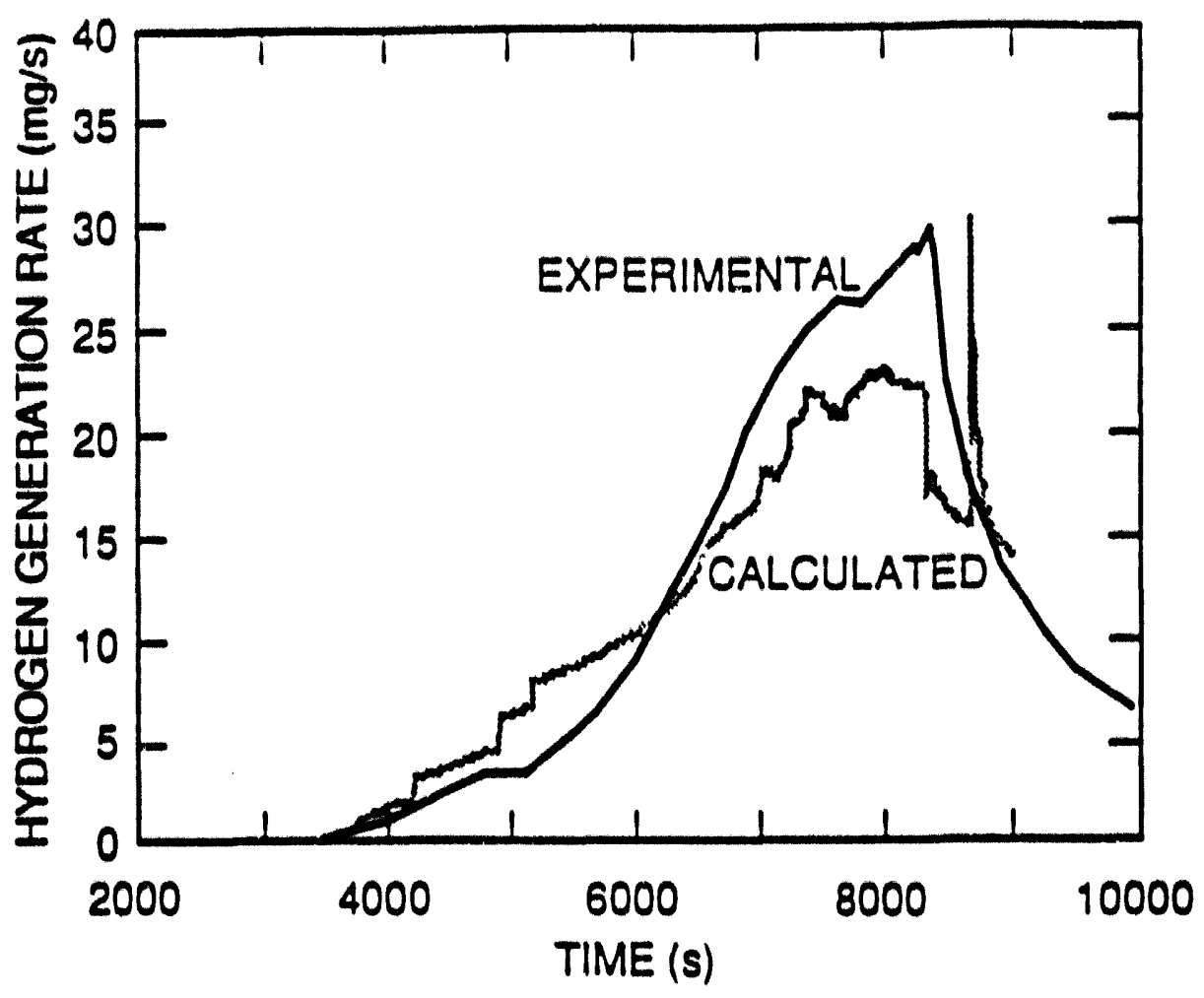

Figure 3. CORA-33 hydrogen generation rate.

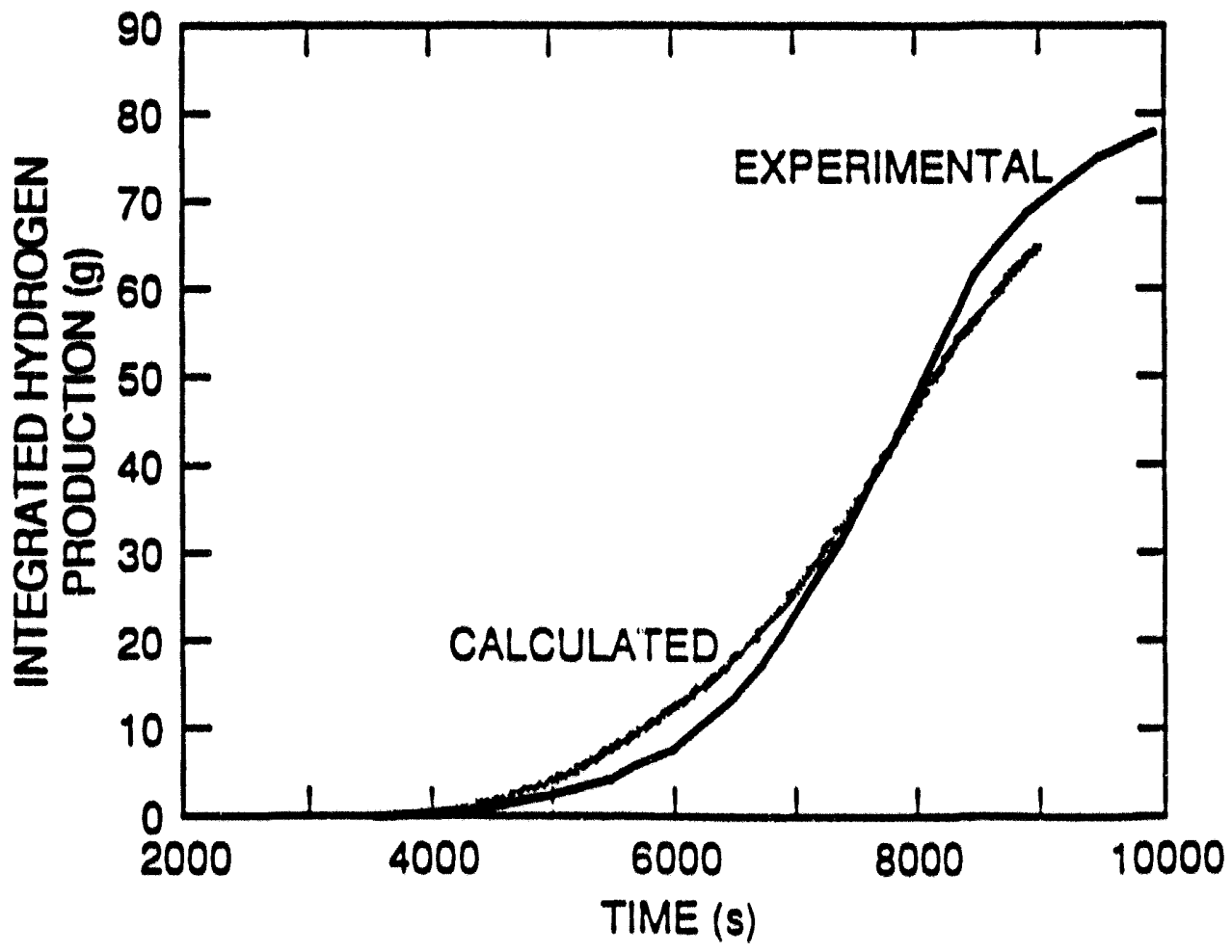

Figure 4. CORA-33 accumulated hydrogen production. 

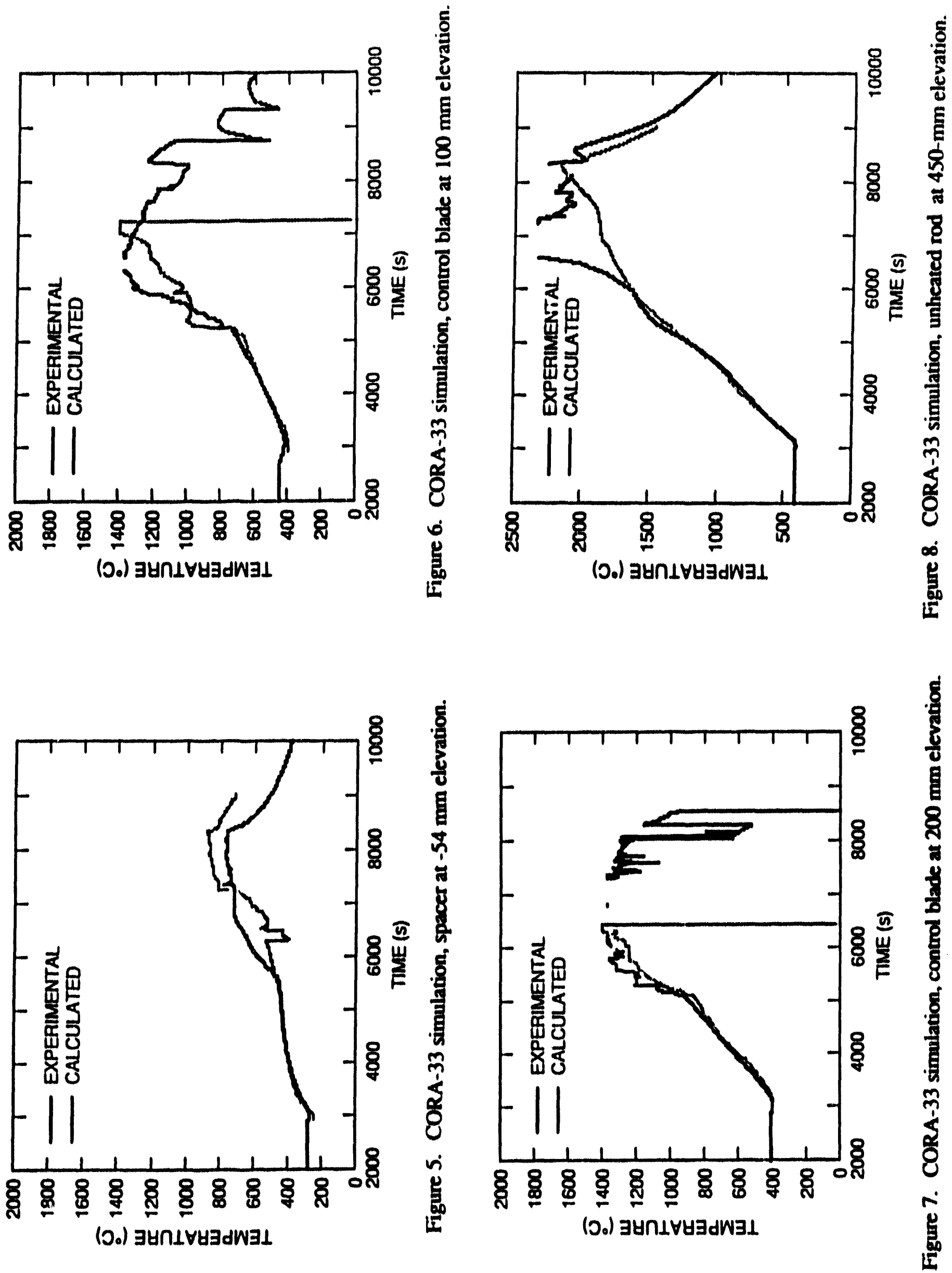


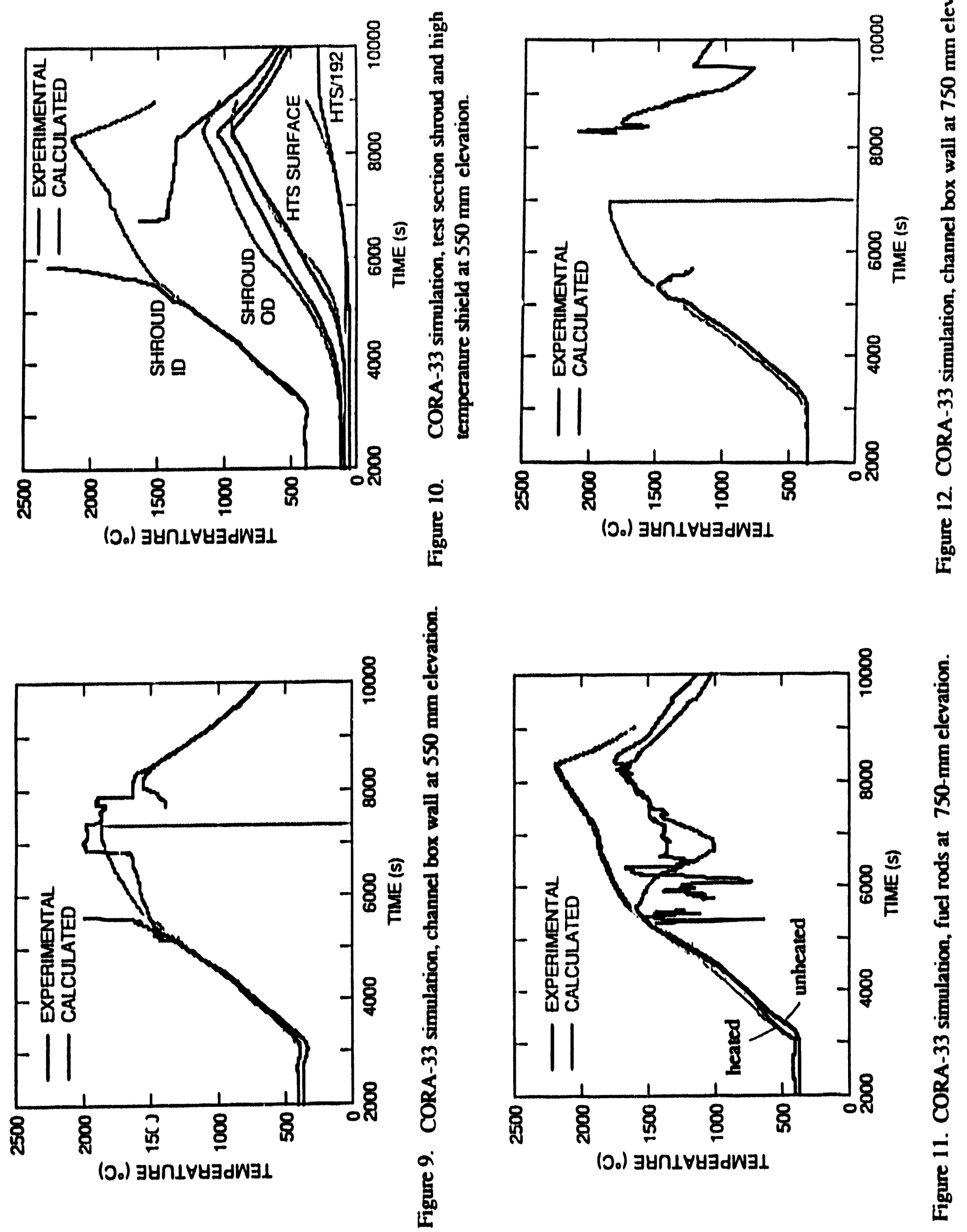



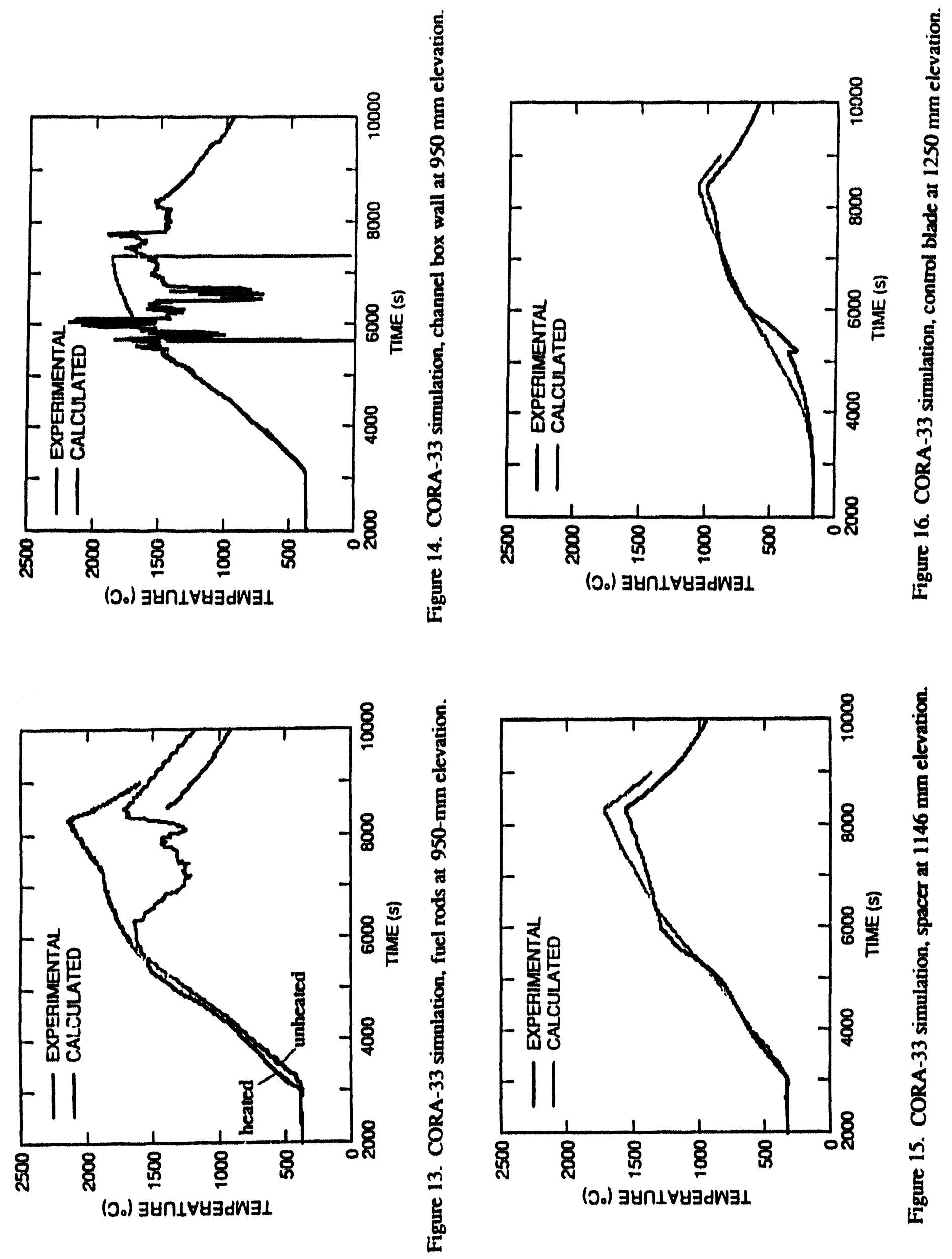




Figure 17. CORA-33 test section relative blockage. 
- Interaction models

- KFK separate effects studies (P. Hotmann)

- Stainless steel/ $\mathrm{B}_{4} \mathrm{C}$

- Stainless steel/Zircaloy

- Relocation

- Film flow with freezing and remelting

- Flow allowed in $x \cdot y-z$ directions

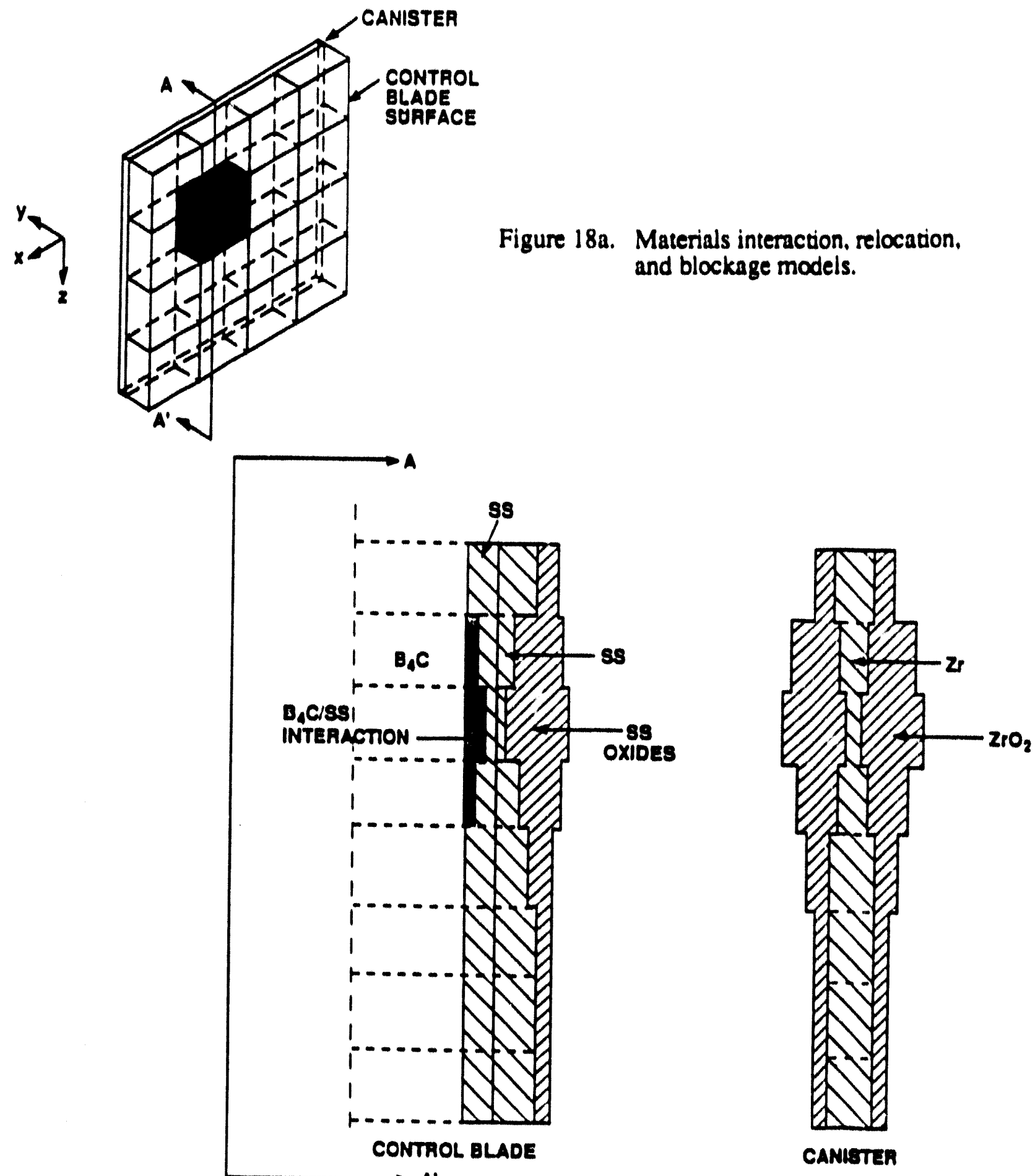

Figure 18b. Conceptualization of structural liquefaction, material dissolution. and eutectic relocation for the BWR control blade/canister. 


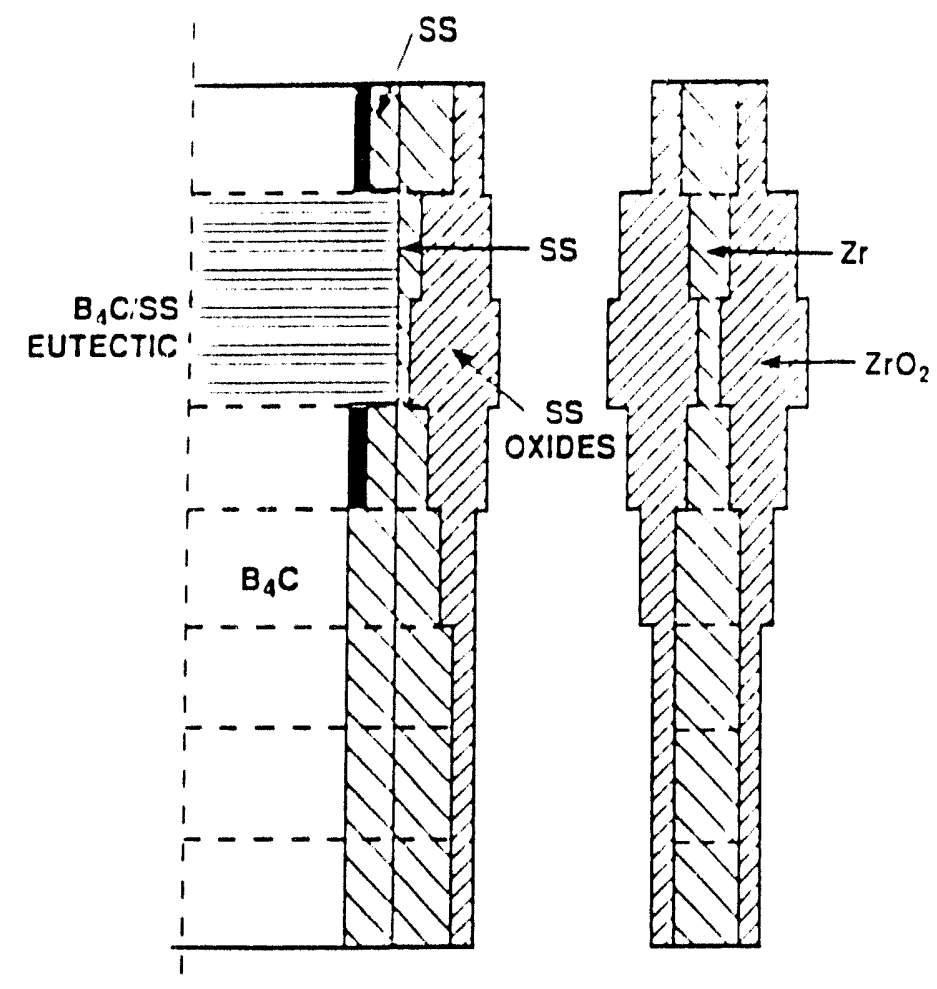

Figure 18c. Absorber tube liquefaction.

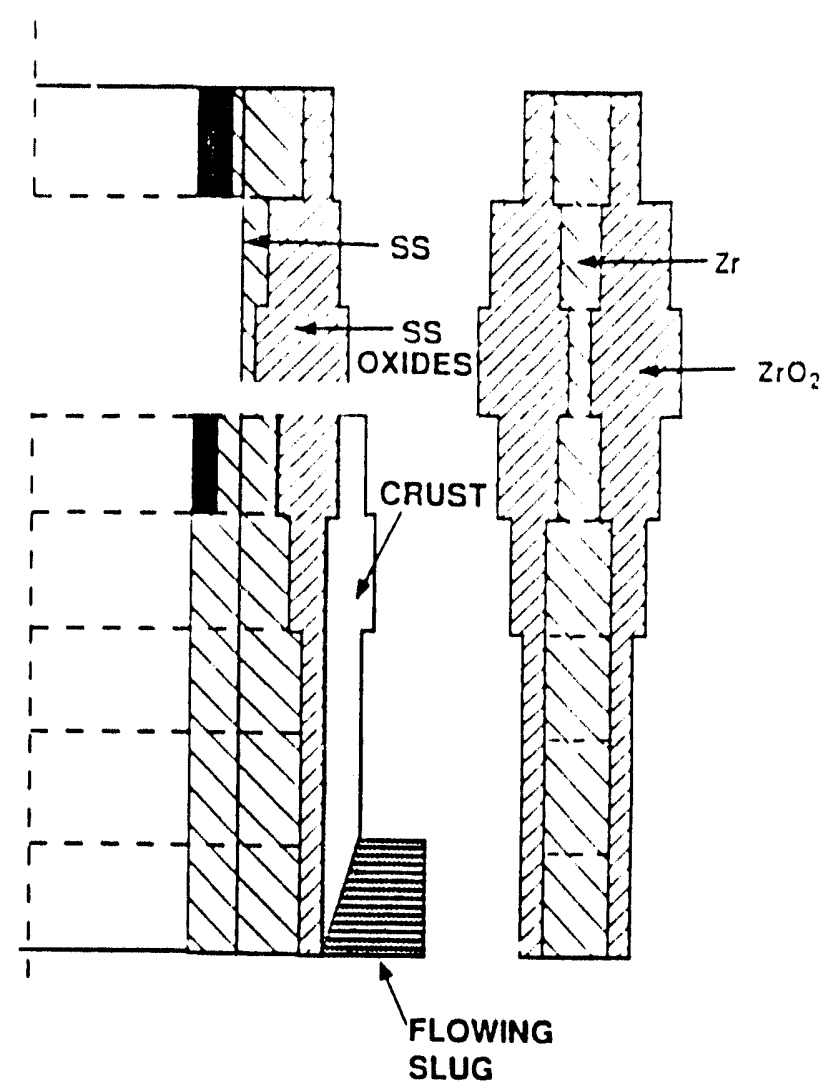

Figure $18 \mathrm{~d}$. $\mathrm{SS} / \mathrm{B}_{4} \mathrm{C}$ eutectic relocation with freezing.

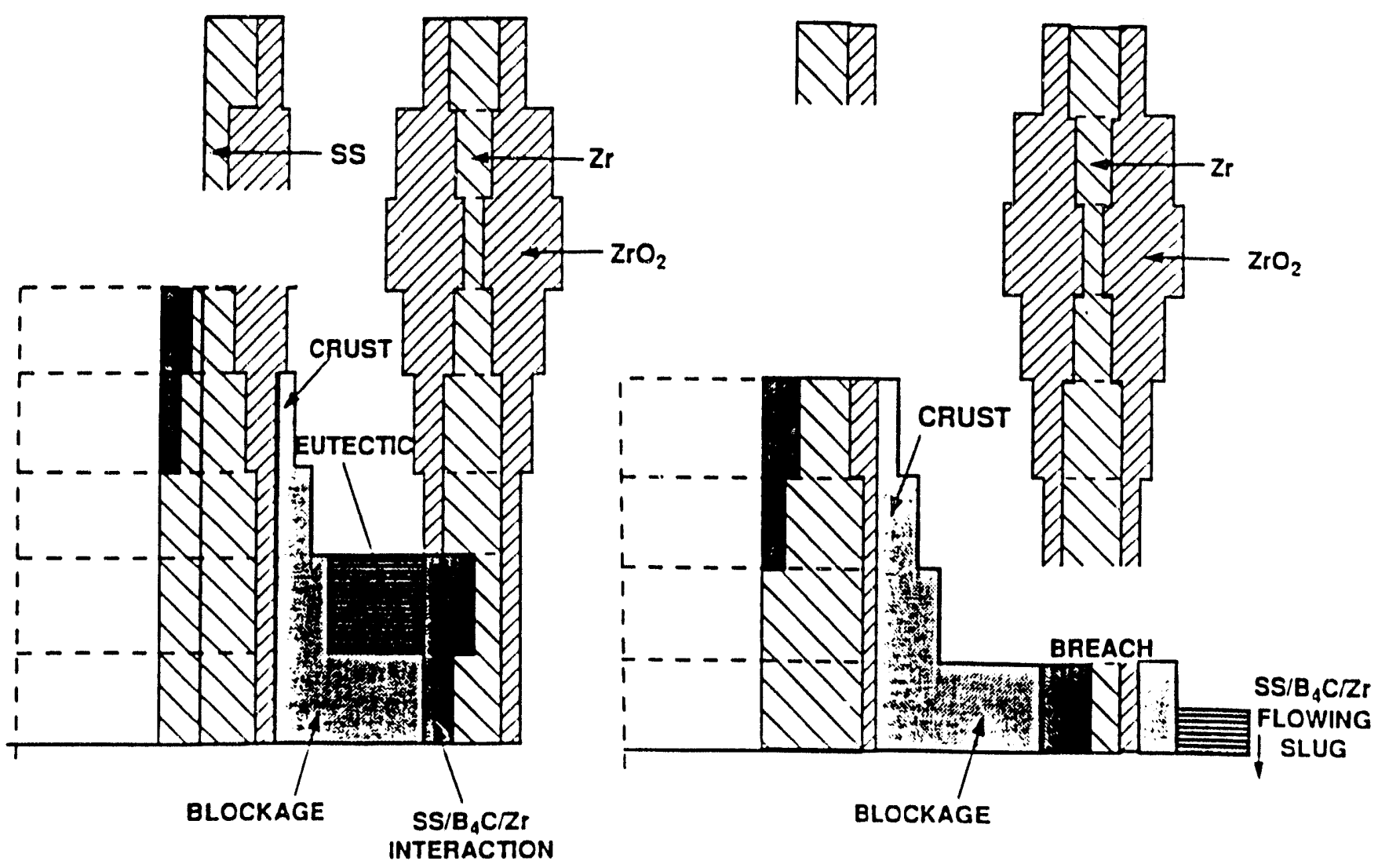

Figure 18e. Blockage with $\mathrm{SS} / \mathrm{B}_{4} \mathrm{C} / \mathrm{Zr}$ interaction.

Figure 18f. Canister break with $\mathrm{SS} / \mathrm{B}_{4} \mathrm{C} / \mathrm{Zr}$ eutectic relocation. 

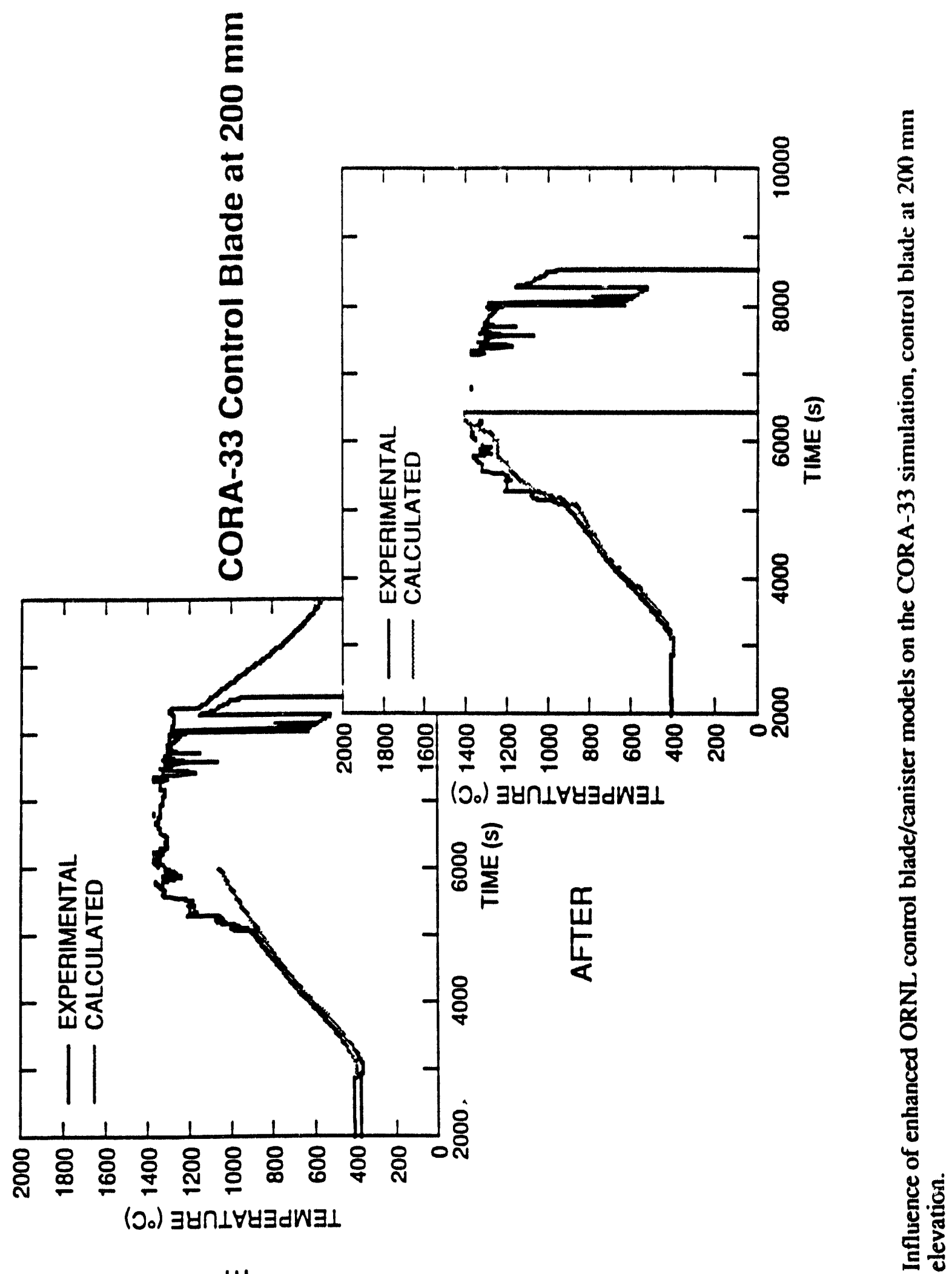

$\frac{w}{\frac{1}{0}}$

$\frac{2}{2}$ 
Figure 2(). (Cross-sectuons of ( ( ) RA 33

hundle from $\cdot(x) \mathrm{mm}$ (1) $18.5 \mathrm{~mm}$.
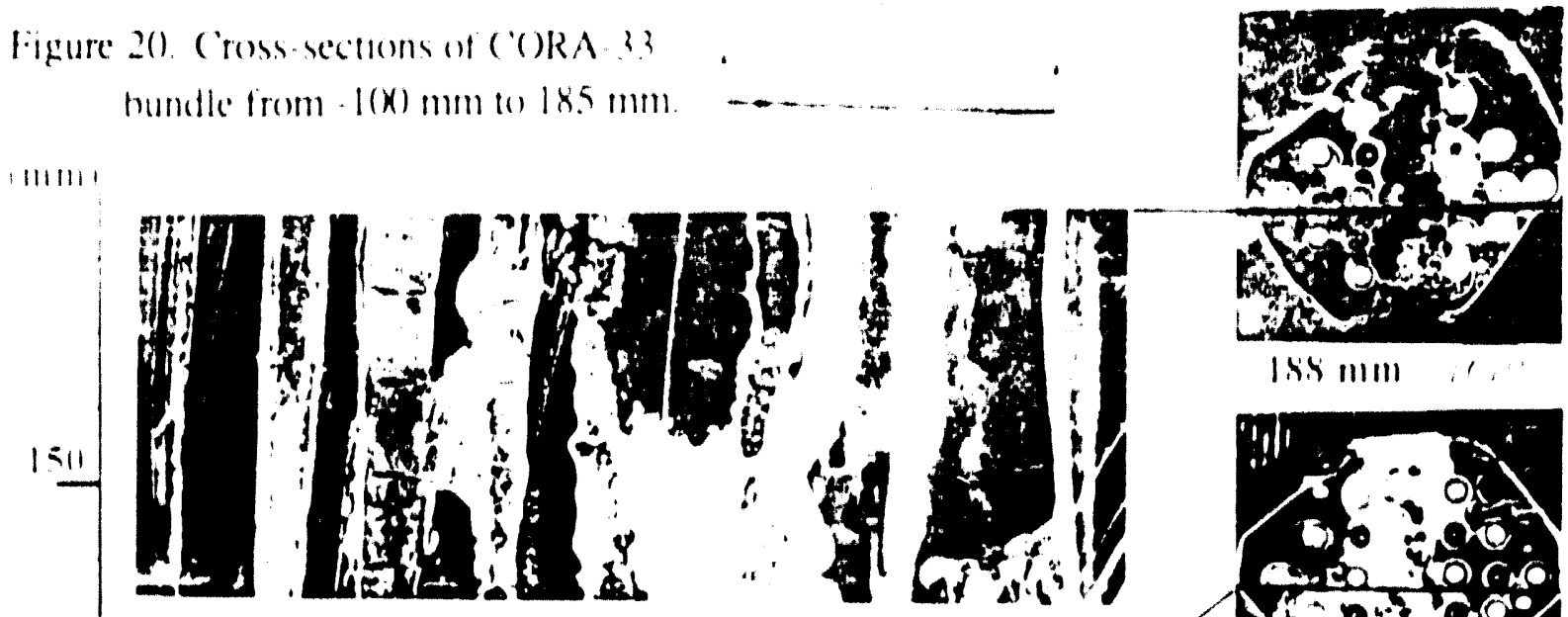

$15.5 \mathrm{mIII}$
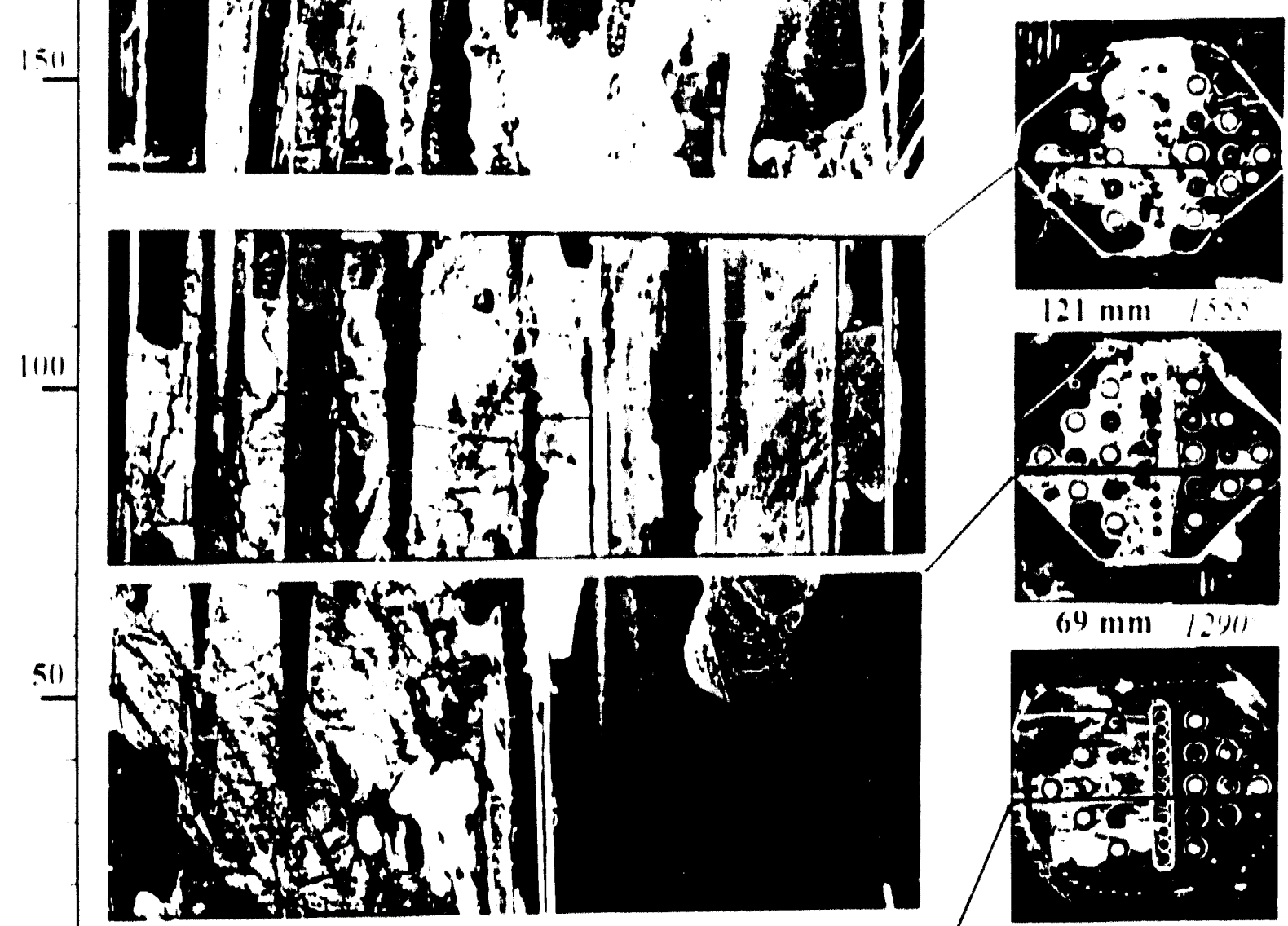

$121 \mathrm{~mm} \quad 1 \therefore$

IIIII
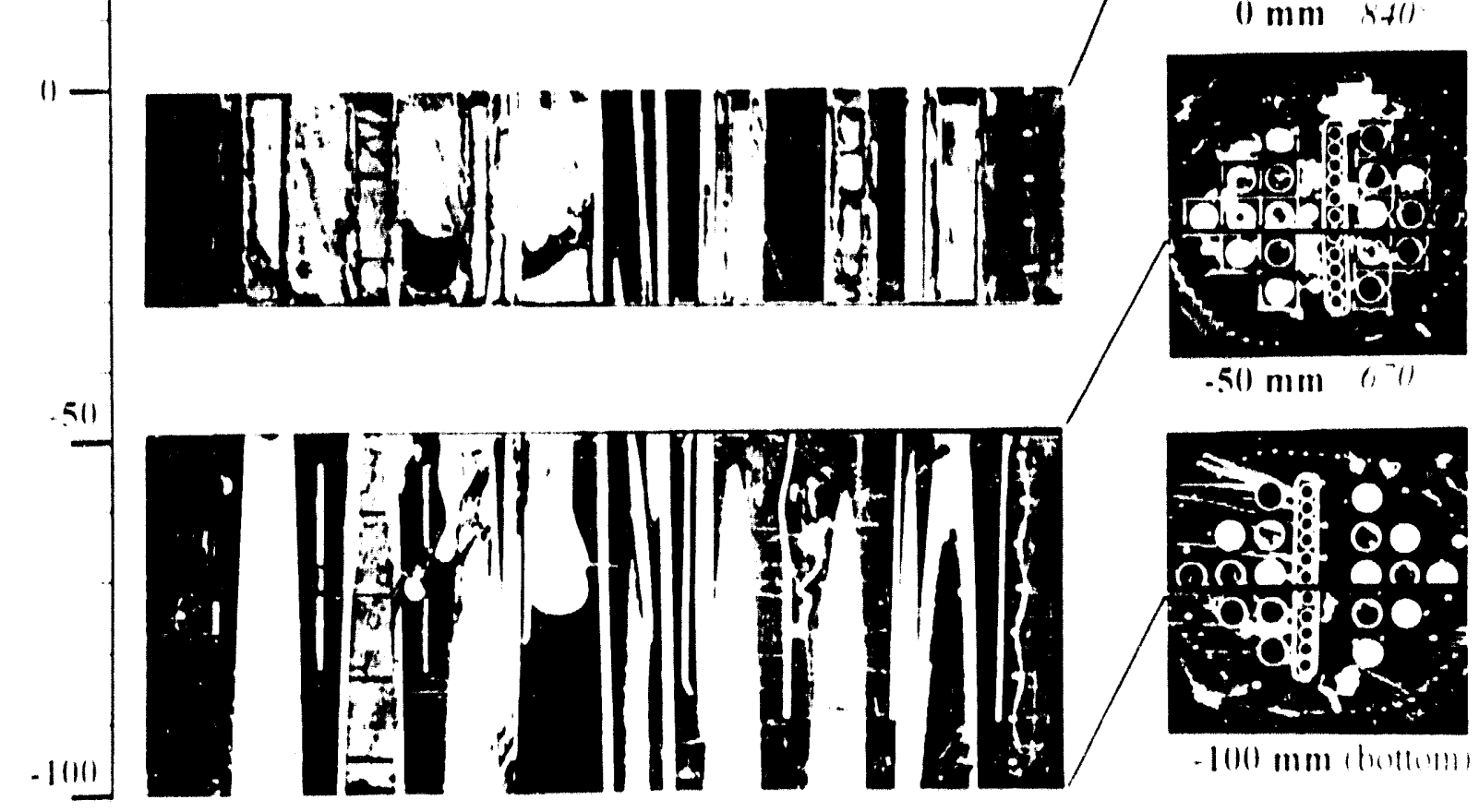


\title{
Interpretation of the Results of the CORA-33 Dry Core BWR Test
}

\author{
L. J. Ott*
}

\section{Boiling Water Reactor Core Melt Progression Phenomena Program Oak Ridge National Laboratory Oak Ridge, Tennessee}

\section{Siegfried Hagen Kernforschungszentrum Karlsruhe 7500 Karlsruhe 1, Federal Republic of Germany}

\author{
Presented at \\ Twenty-First Water Reactor Safety \\ Information Meeting \\ Bethesda, Maryland \\ October 26, 1993
}

- Research sponsored by the Otfice of Nudear Regulatory Recearch, U.S. Nuctear Rogulatory Commission under Interagency Agreement No. 1886-8136-6L with the U.S. bepartment of Energy under contract DE.AC05-84OR21400 with Martin Marietta Energy Systems, Inc.
The submitted manuecript has been authored by a contractor of the U.S. Government under contract No. DE-ACO5-84OR21400. Accordingly, the U.S. Government retains a nonexclusive, royaly-free license to publish or reproduce the published form of this contribution, or allow others to do so, for U.S. Government purposes." 


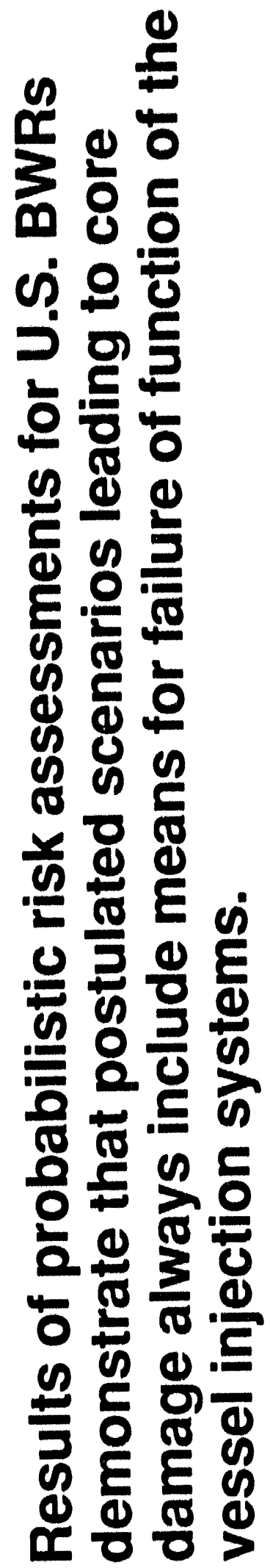




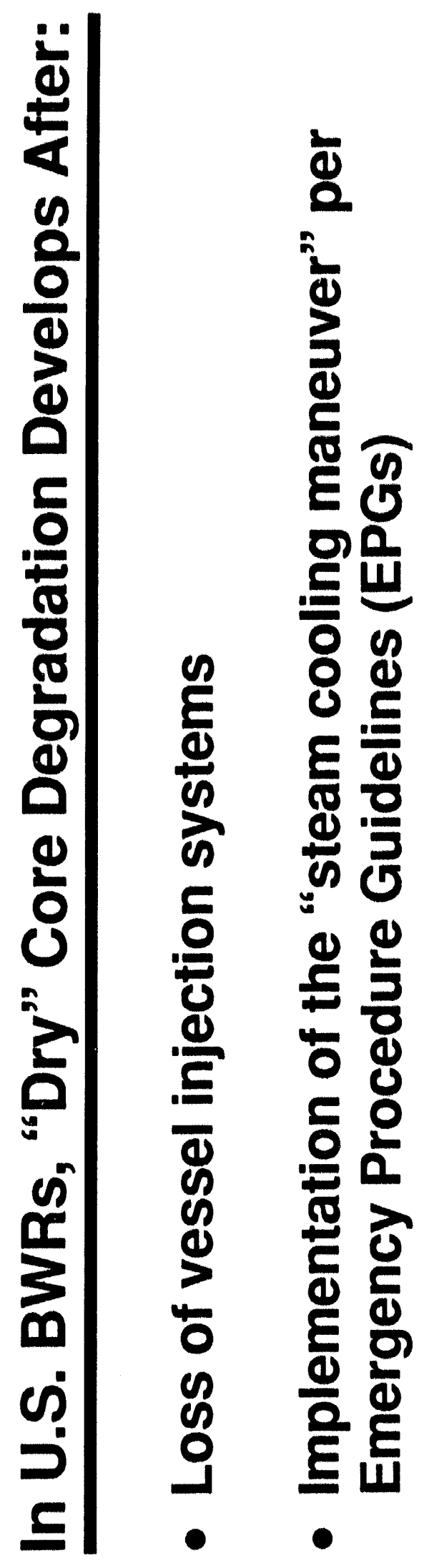


Emergency Procedure Guidelines Call For Manual Actuation of ADS Valves at or About One-Third Core Height; Flashing Drops Water Level Below the Core Plate

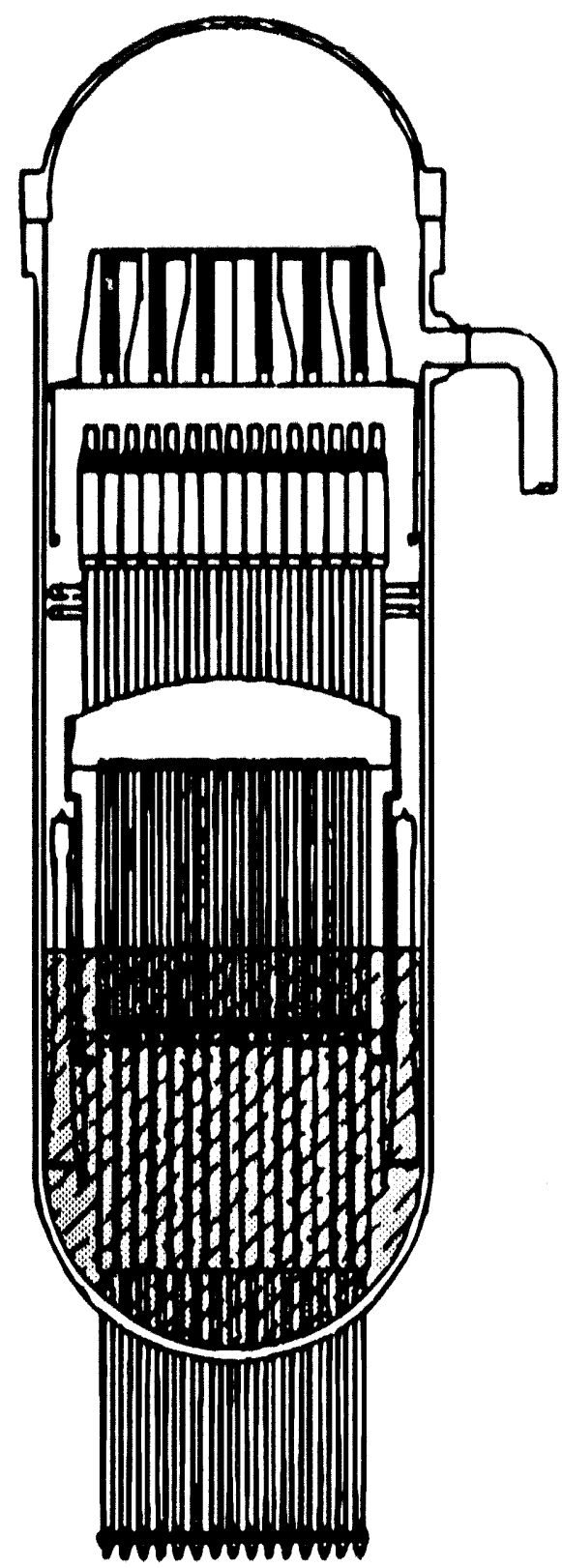

OHNL.DWG B9M-4197AC ETD

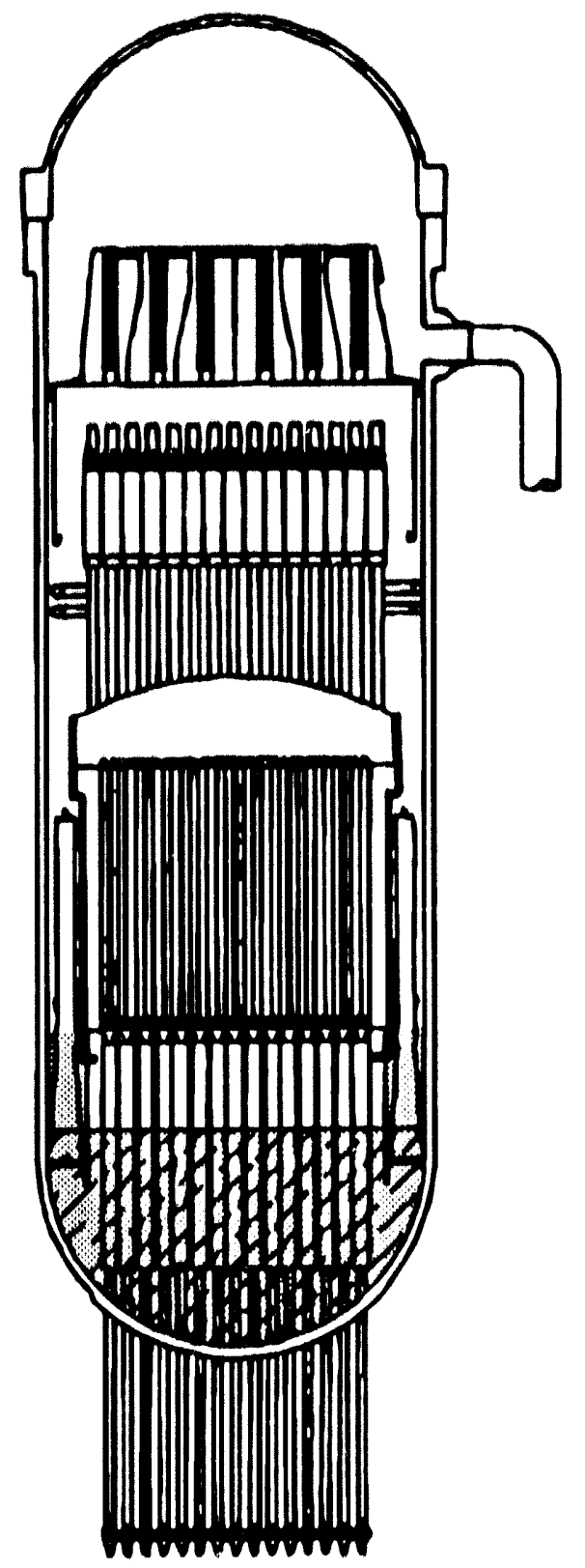

ornl 


\section{The Steam Cooling Maneuver is Effective}
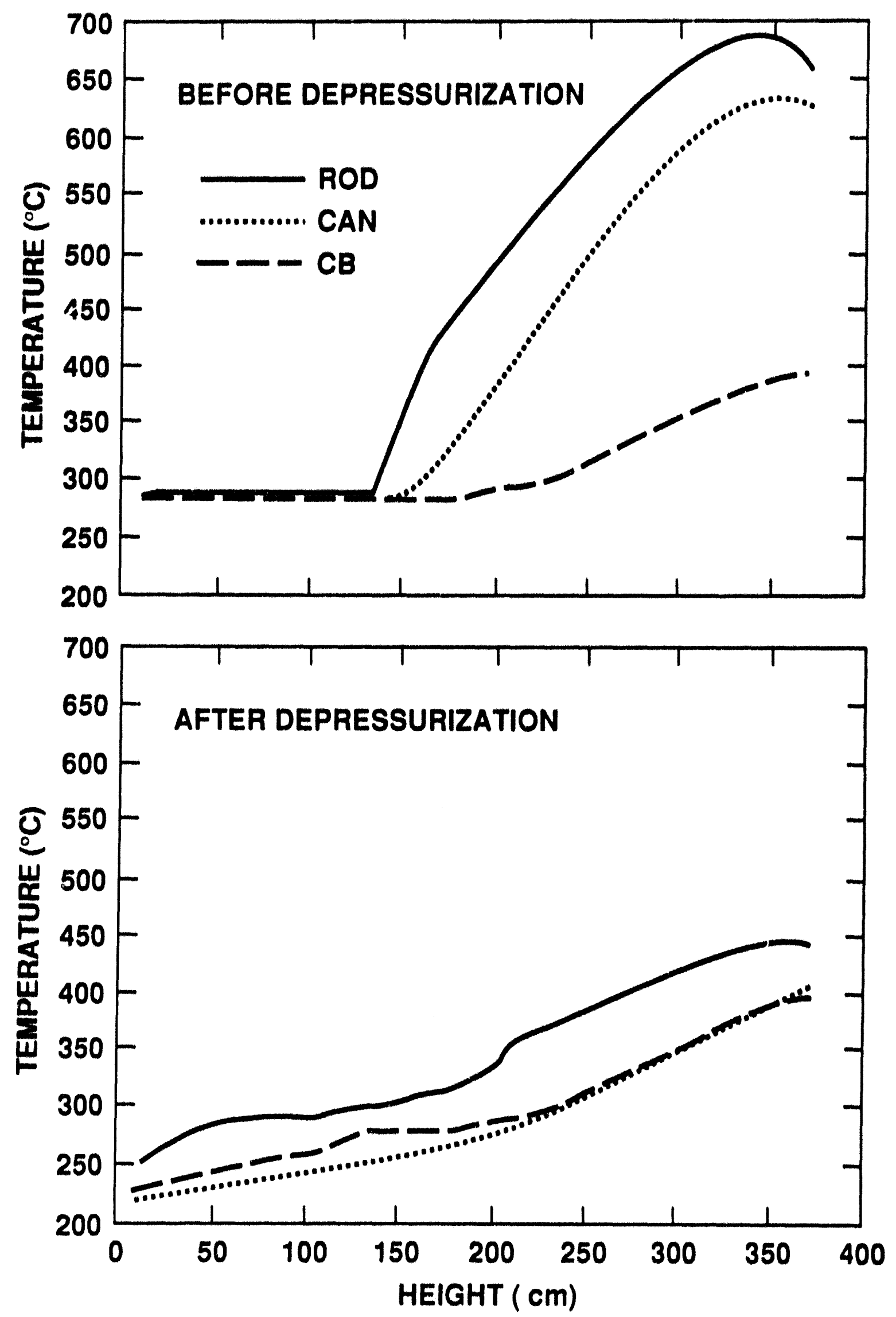


\section{'Dry Core' Accident Sequence Characteristics}

- No Injection

- Vessel depressurized

- Bolloff with flashing during depressurlzation

- Steam-starved core degradation
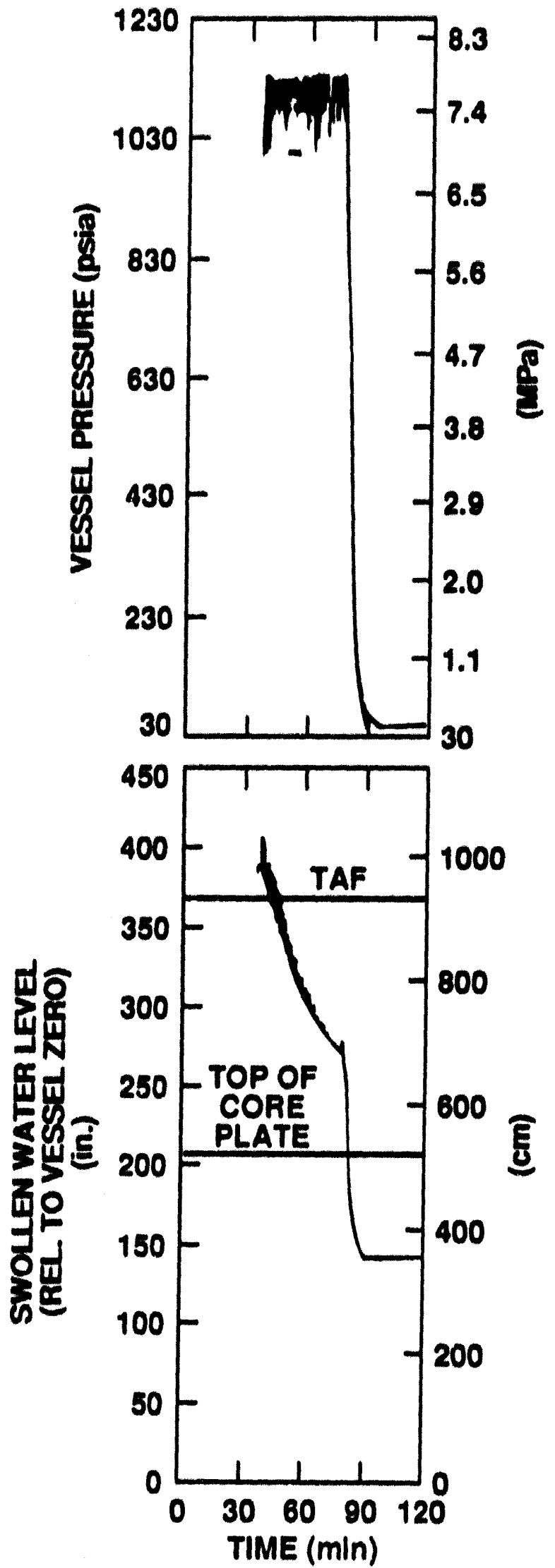


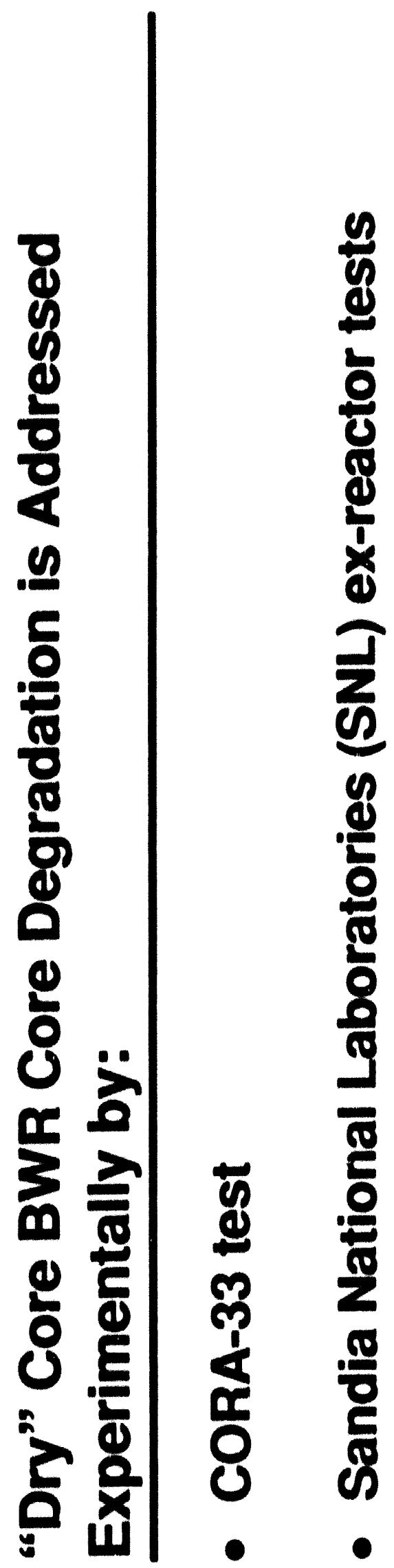



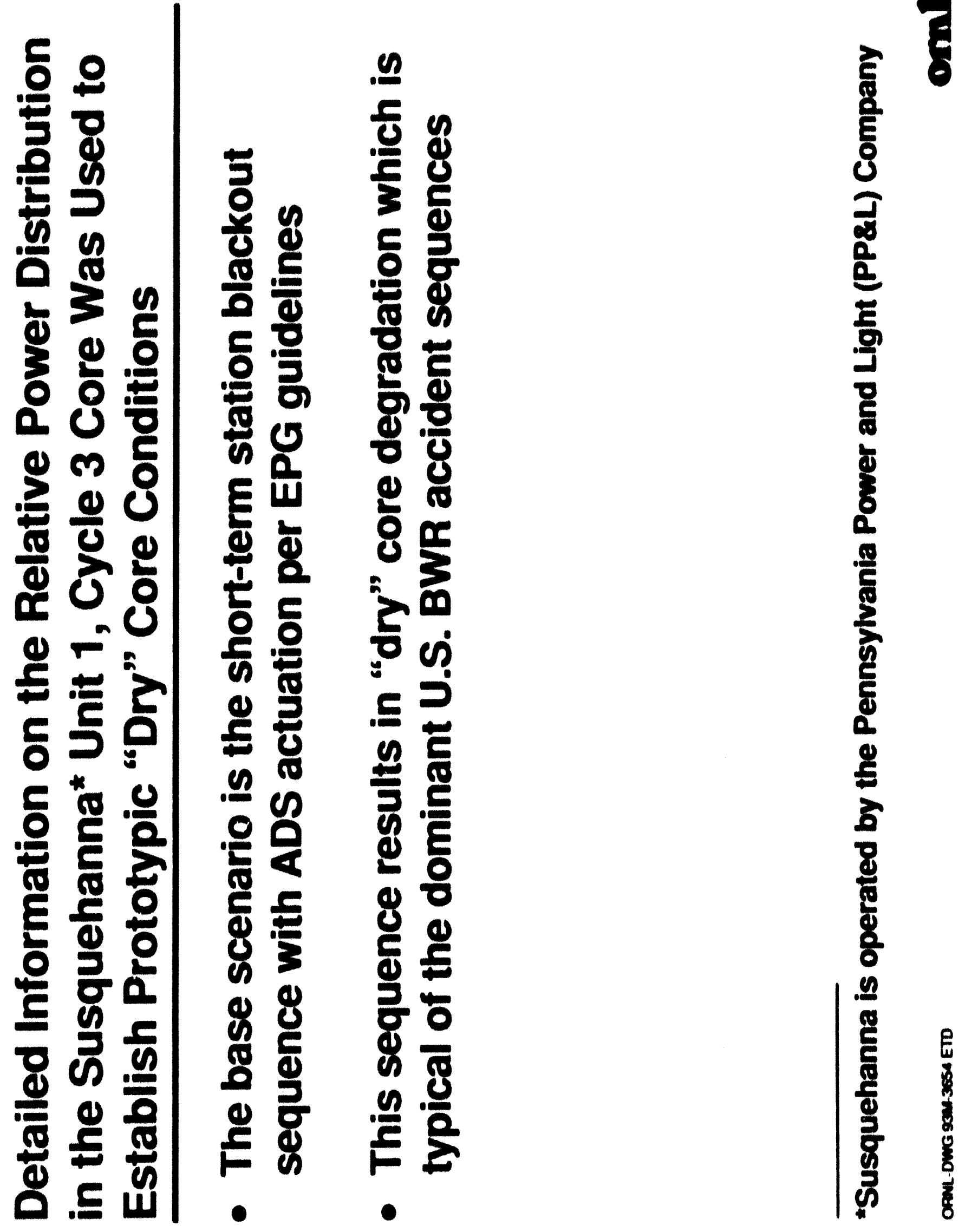


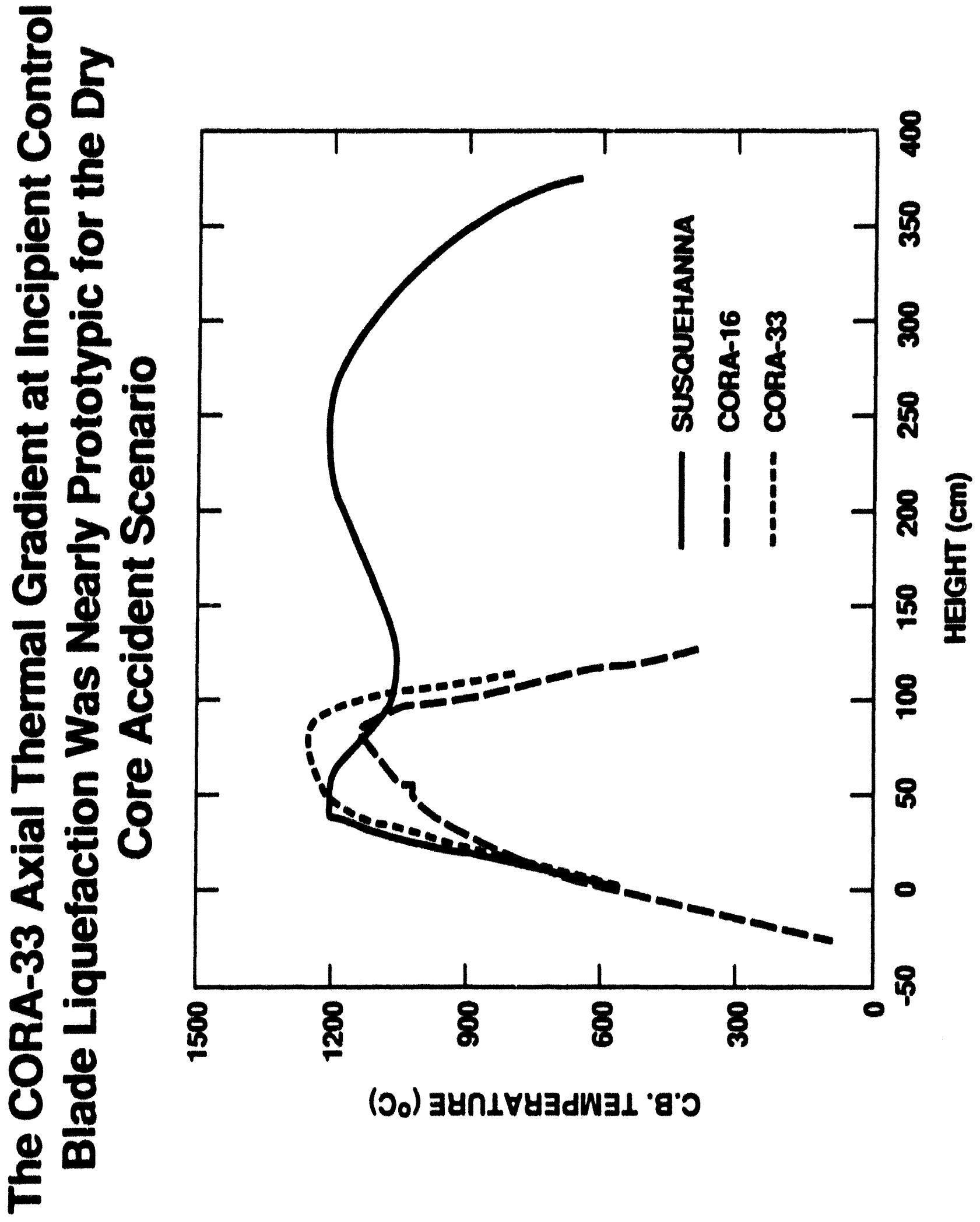




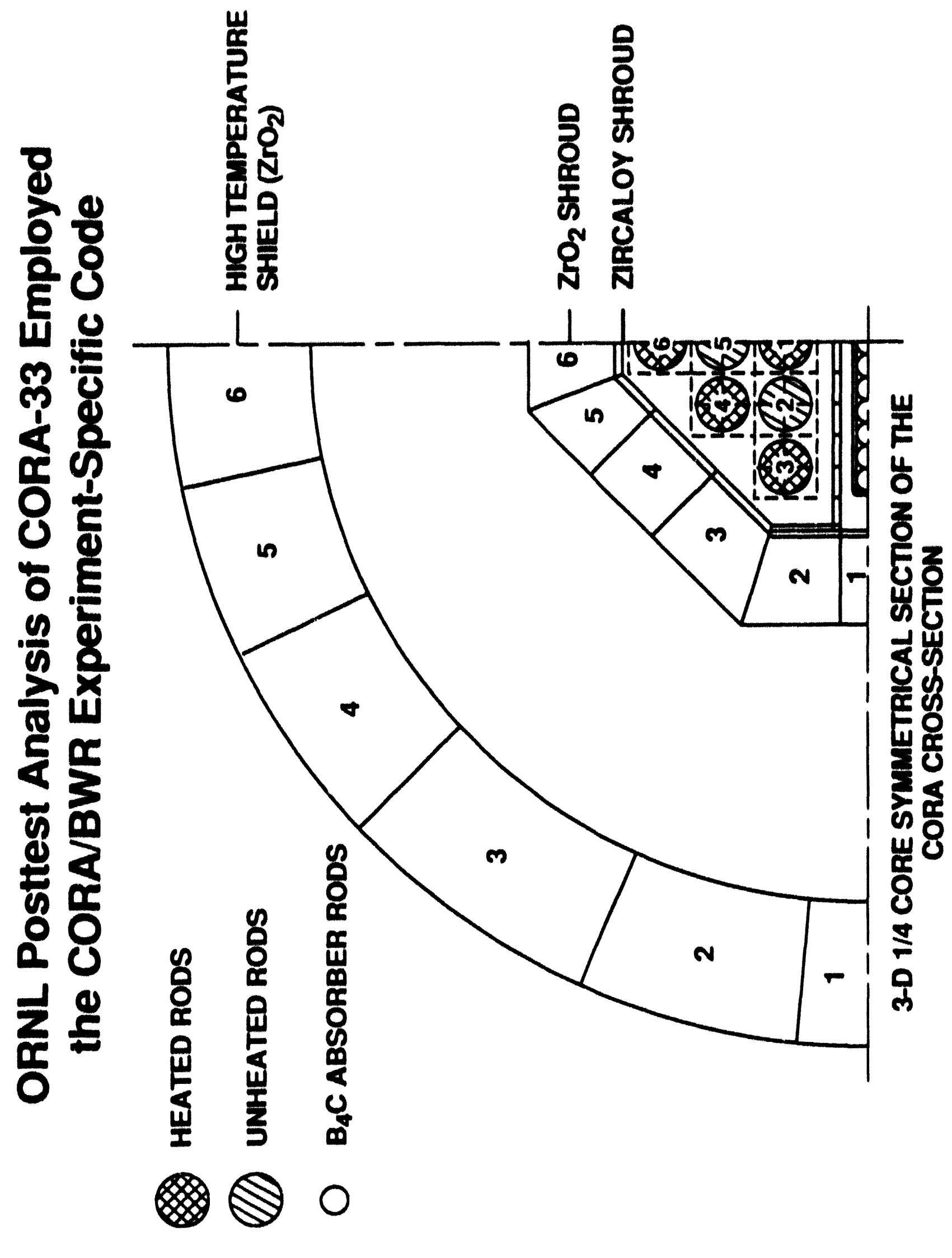

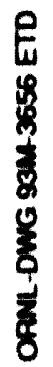




\section{Significant Events in CORA-33 Test Simulation}

Event

Time (s)

Reduction of test section Argon flow

2700

Electric power Increase (start of transient)

3000

Cumulative $\mathrm{H}_{2}$ generation $>1 \mathrm{gm}$

4310

Rod cladding temperature $>1000^{\circ} \mathrm{C}$

4360

Inciplent control blade liquefaction $\left(1232.2^{\circ} \mathrm{C}\right)$

4904

Rod cladding fallure (due to overpressure)

$4940-5012$

Initial control blade/canister flow area blockage

5068

$(325-375 \mathrm{~mm}$ ) (also initlation of stainless

steel/Zircaloy interaction)

Significant breach of canister and melt flow down

5230 Inside of canister $(225-375 \mathrm{~mm})$

Blockage of flow channel inside surface of canister

5280

and diversion of melt laterally into fuel assembly

(75-125 mm)

Blockage of flow channel around rods 1 and 3

(25-125 mm)

Control blade from $475-975 \mathrm{~mm}$ completely liquefled

Clad melting starts $\left(1852^{\circ} \mathrm{C}\right)$

5580

- At this time, $\sim 970 \mathrm{~mm}$ of control blade has

liquefied and relocated

- At this time, 250-300 mm of canister has

liquefied and relocated

Canister melting above $375 \mathrm{~mm}$ starts $\left(1852^{\circ} \mathrm{C}\right)$

6774

Shroud liner melting starts $\left(1852^{\circ} \mathrm{C}\right)$

6960

Full bundle power of $22.4 \mathrm{~kW}$ attained

8015

Electrical power terminated

8300

Argon test section flow increased

8330 


\section{CORA-33 Posttest Simulation Results}

\section{Spacer at -54 mm Elevation}

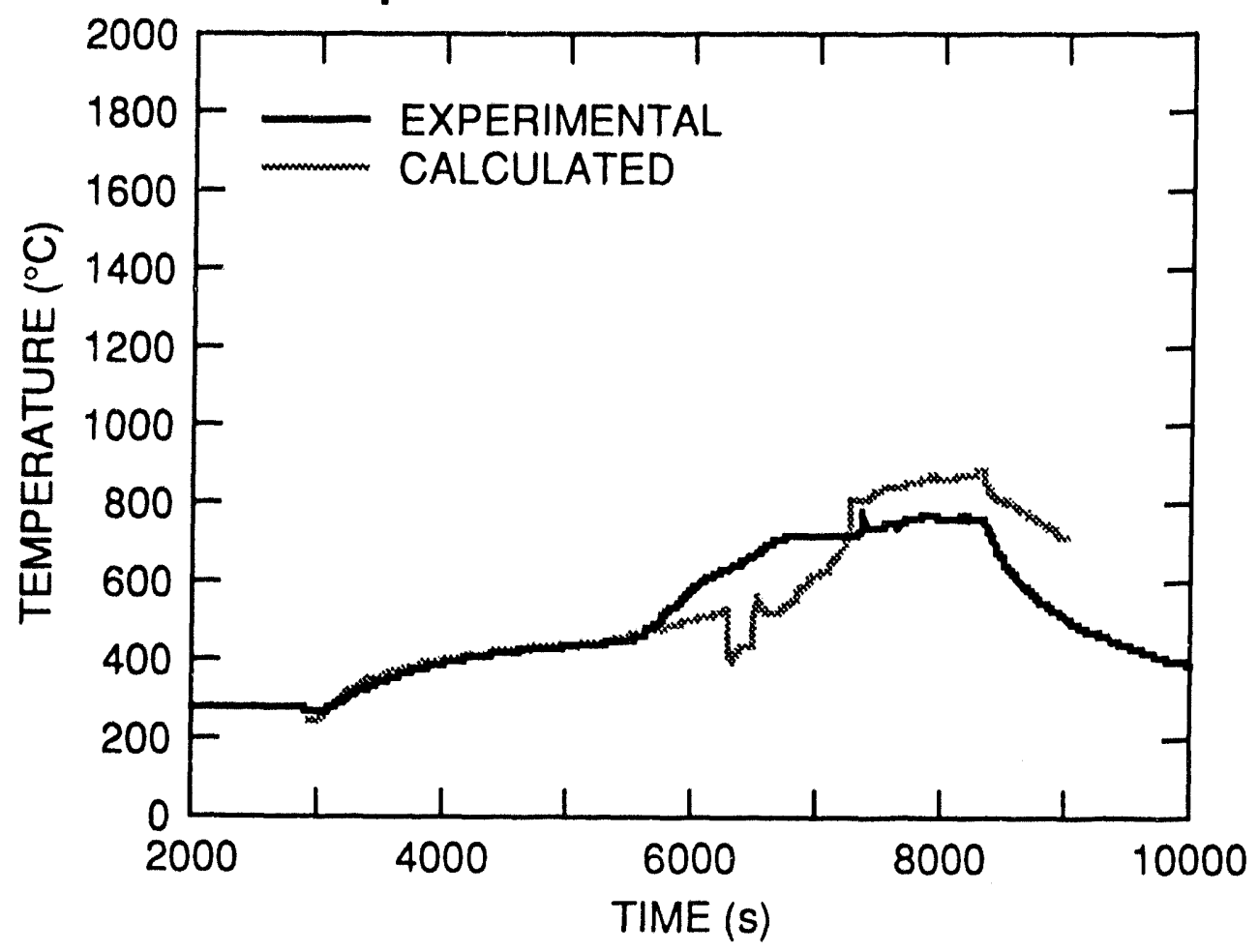

Control Blade at $100 \mathrm{~mm}$ Elevation

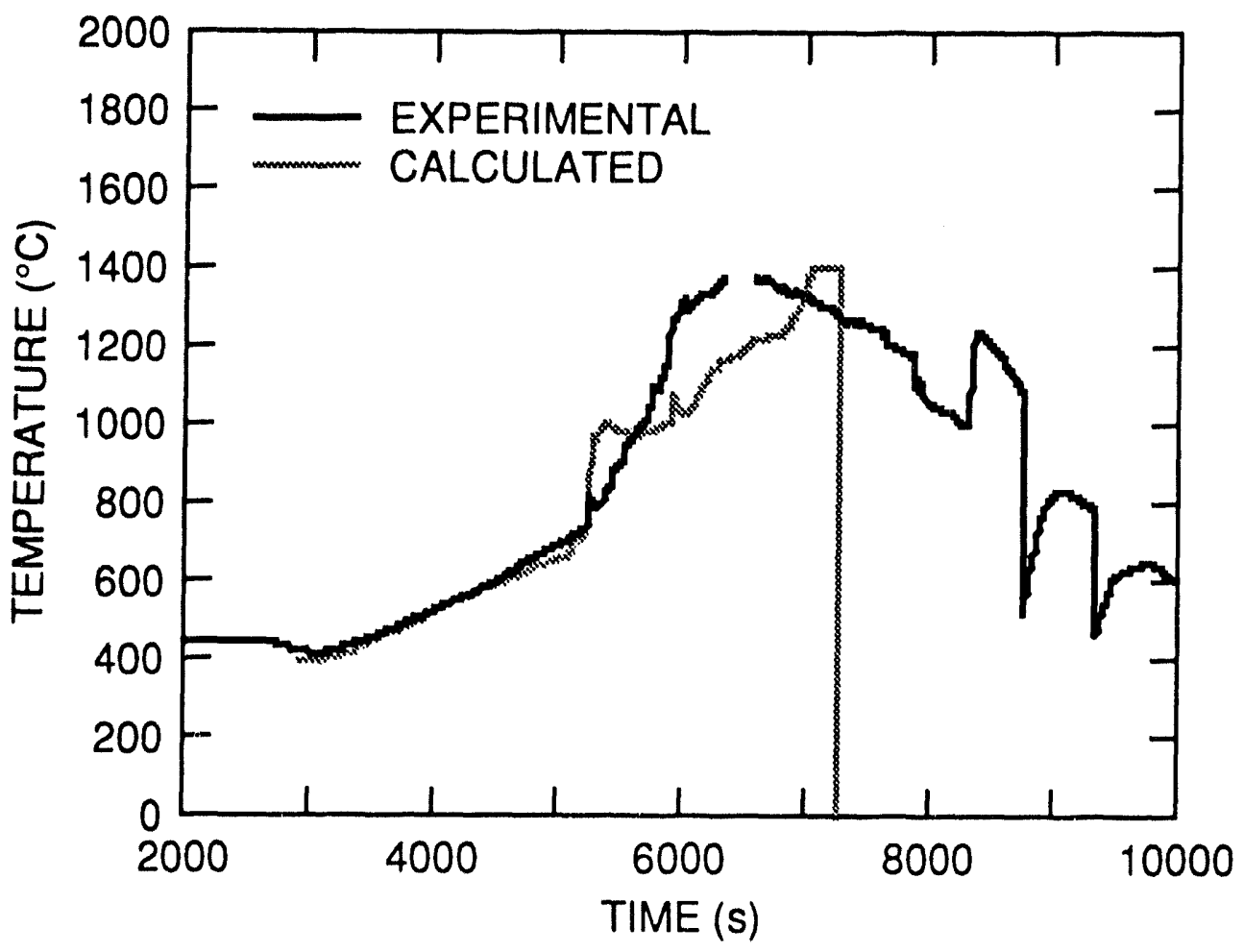

ORNL-DWG 93M-3658 ETD 


\section{CORA-33 Posttest Simulation Results (continued) \\ Control Blade at $200 \mathrm{~mm}$ Elevation}
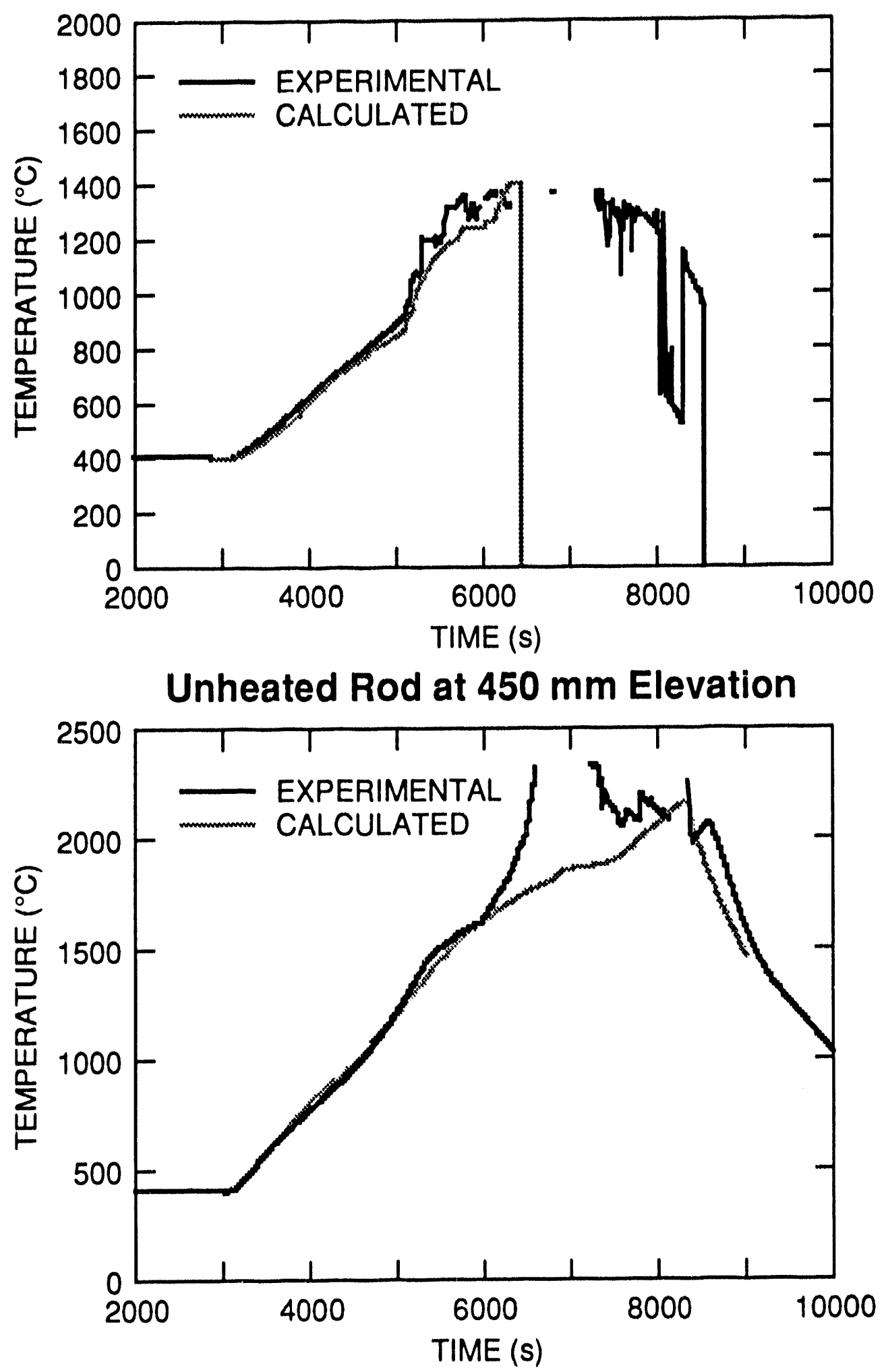

ORNL-DWG 93M-3659 ETD 
CORA-33 Posttest Simulation Results (continued) Channel Box Wall at $550 \mathrm{~mm}$ Elevation

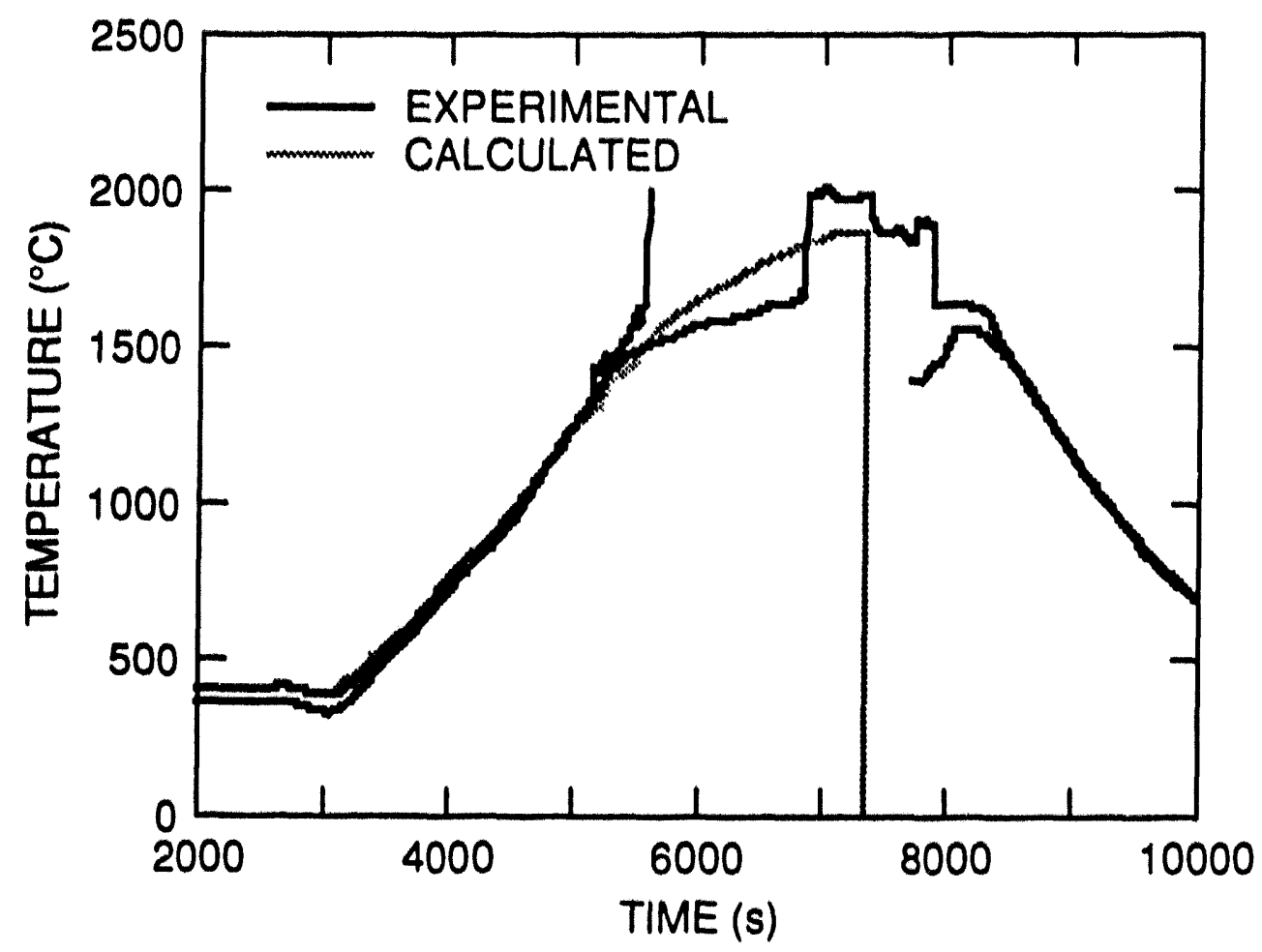

Shroud at $550 \mathrm{~mm}$ Elevation

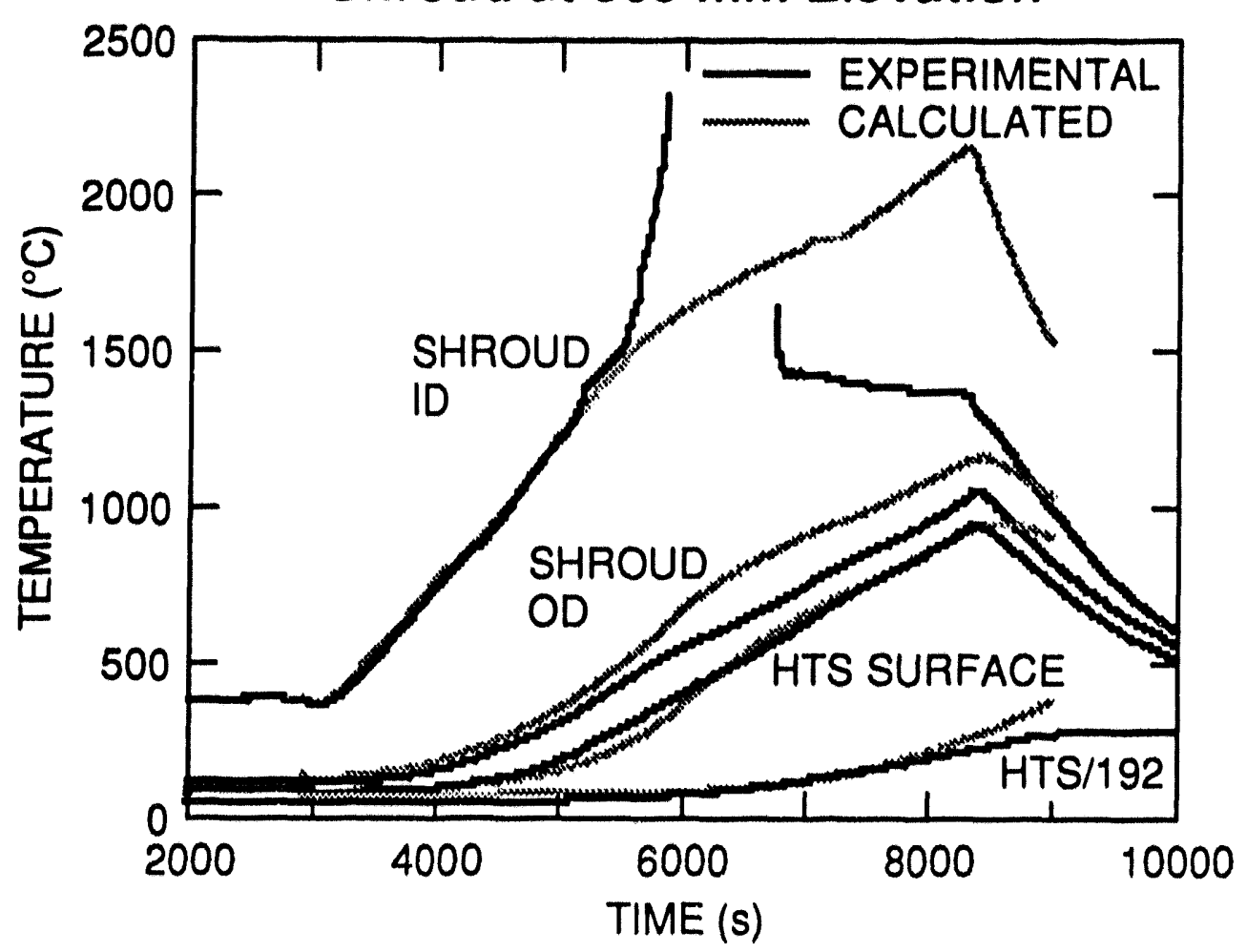

ORNL-DWG 93M-3660 ETD 


\section{CORA-33 Posttest Simulation Results (continued)}

Fuel Rods at $750 \mathrm{~mm}$ Elevation

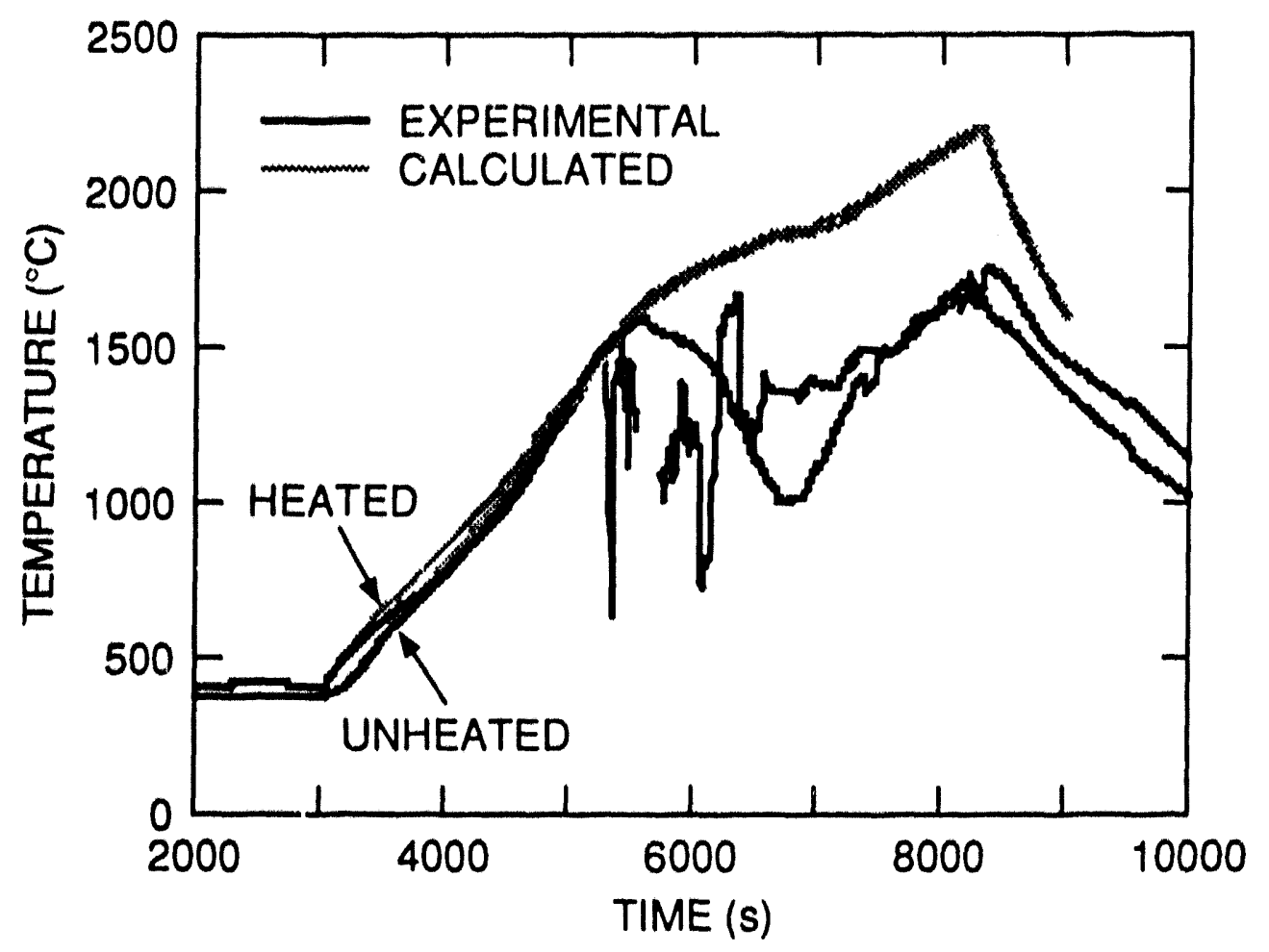

Channel Box Wall at $750 \mathrm{~mm}$ Elevation

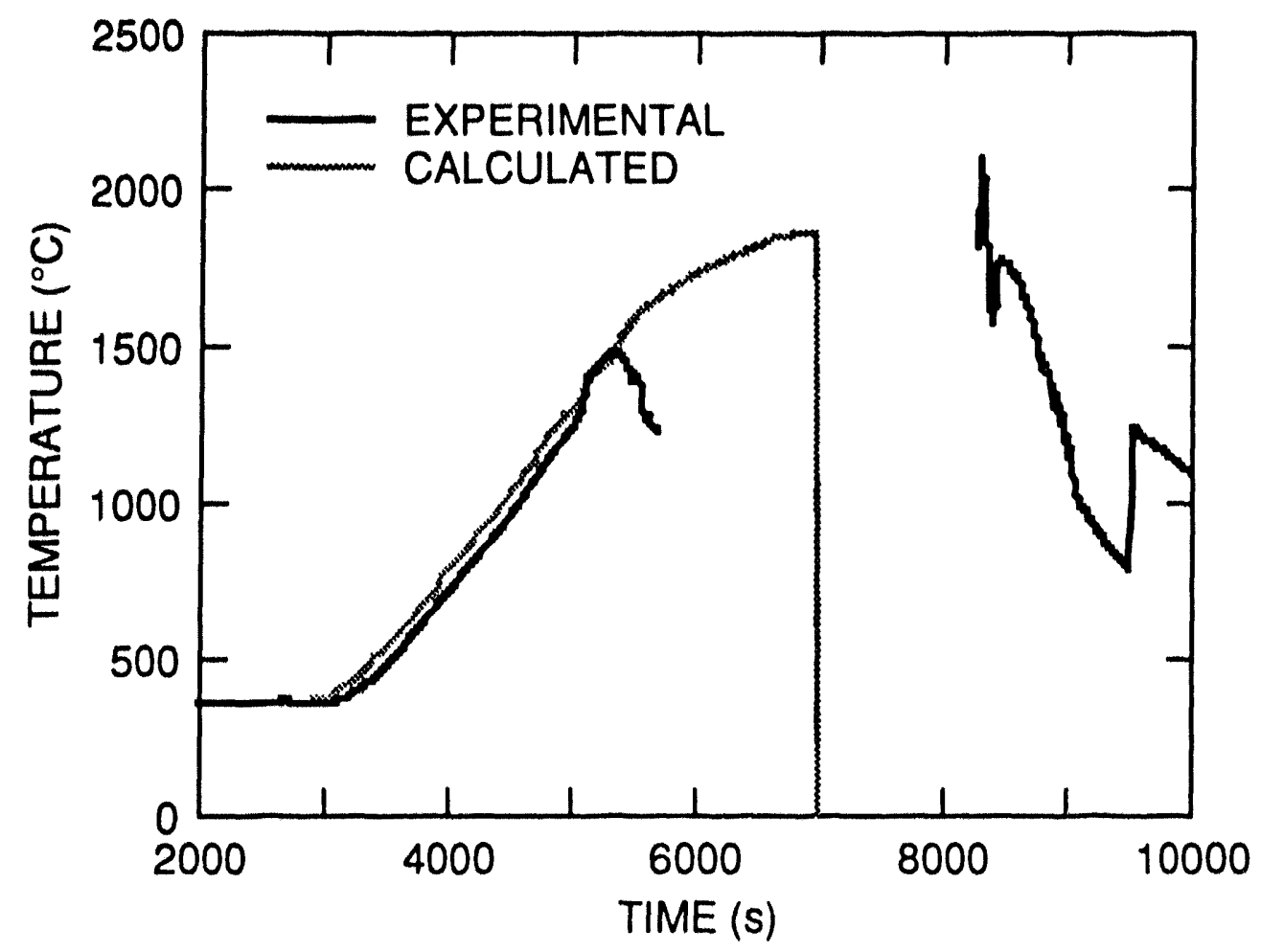

ORNL-DWG 93M-3661 ETD 


\section{CORA-33 Posttest Simulation Results (continued)}

Fuel Rods at $950 \mathrm{~mm}$ Elevation

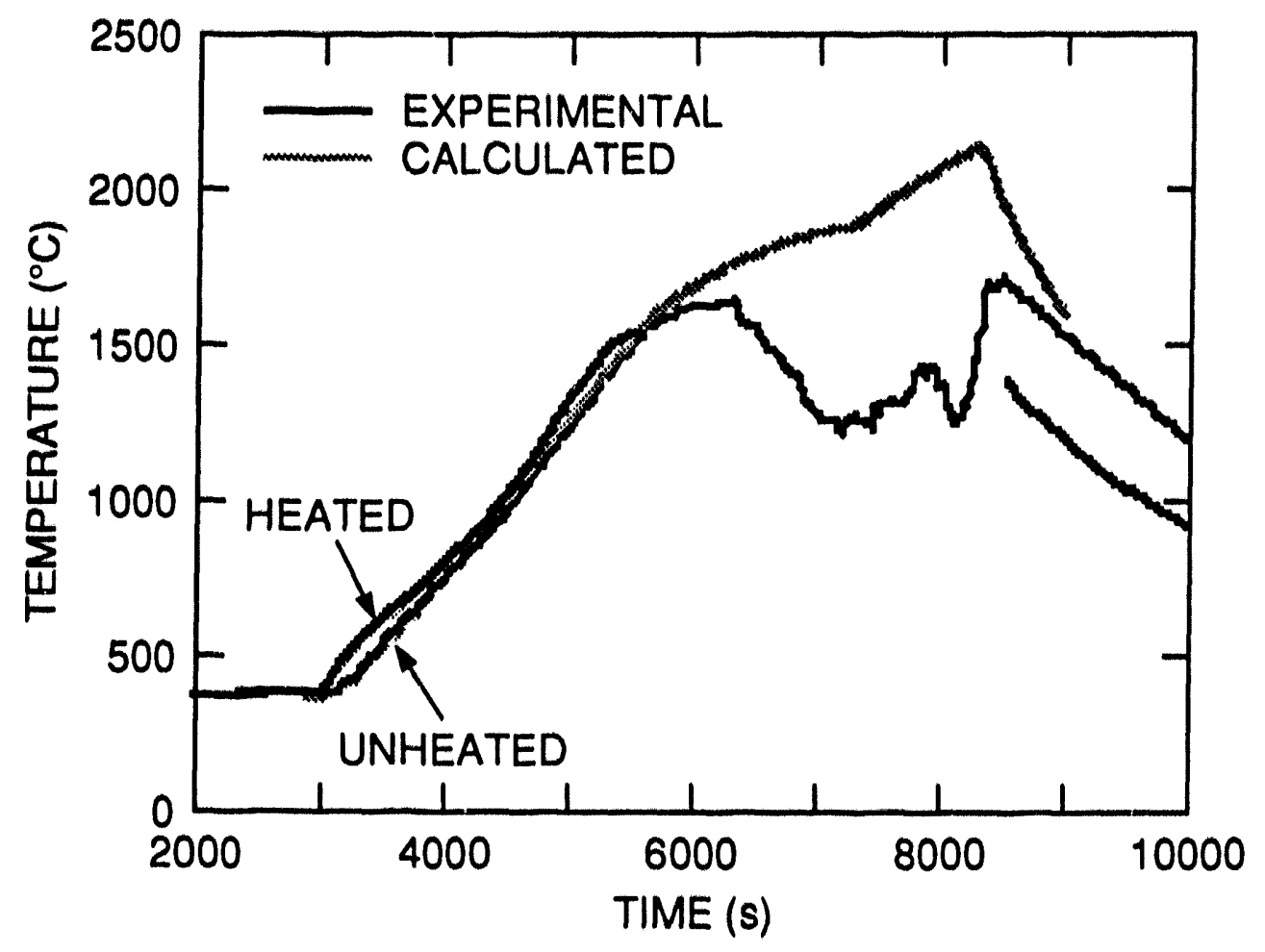

Channel Box Wall at $950 \mathrm{~mm}$ Elevation

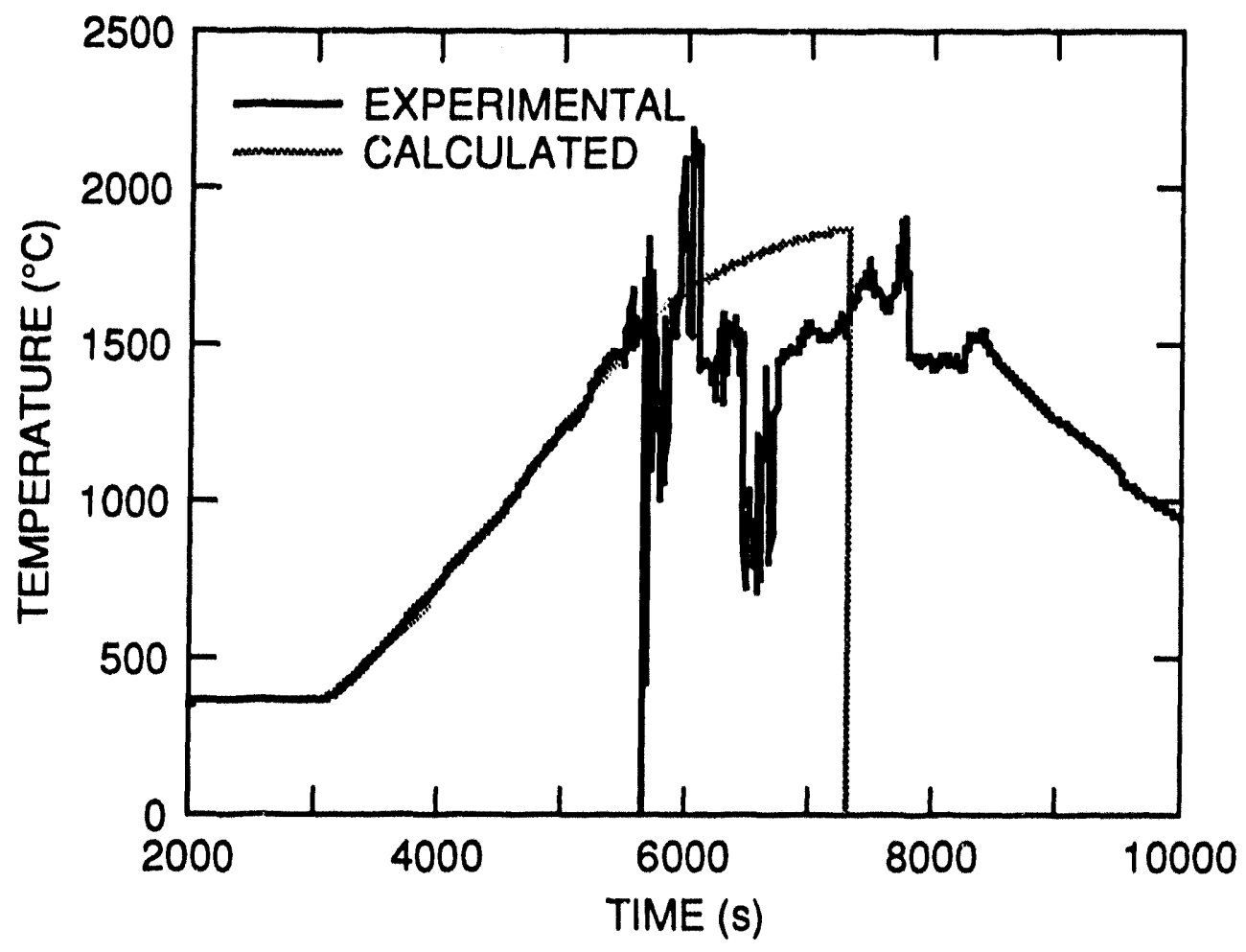

ORNL-DWG 93M-3662 ETD 


\section{CORA-33 Posttest Simulation Results (continued)}

\section{Spacer at $1146 \mathrm{~mm}$ Elevation}
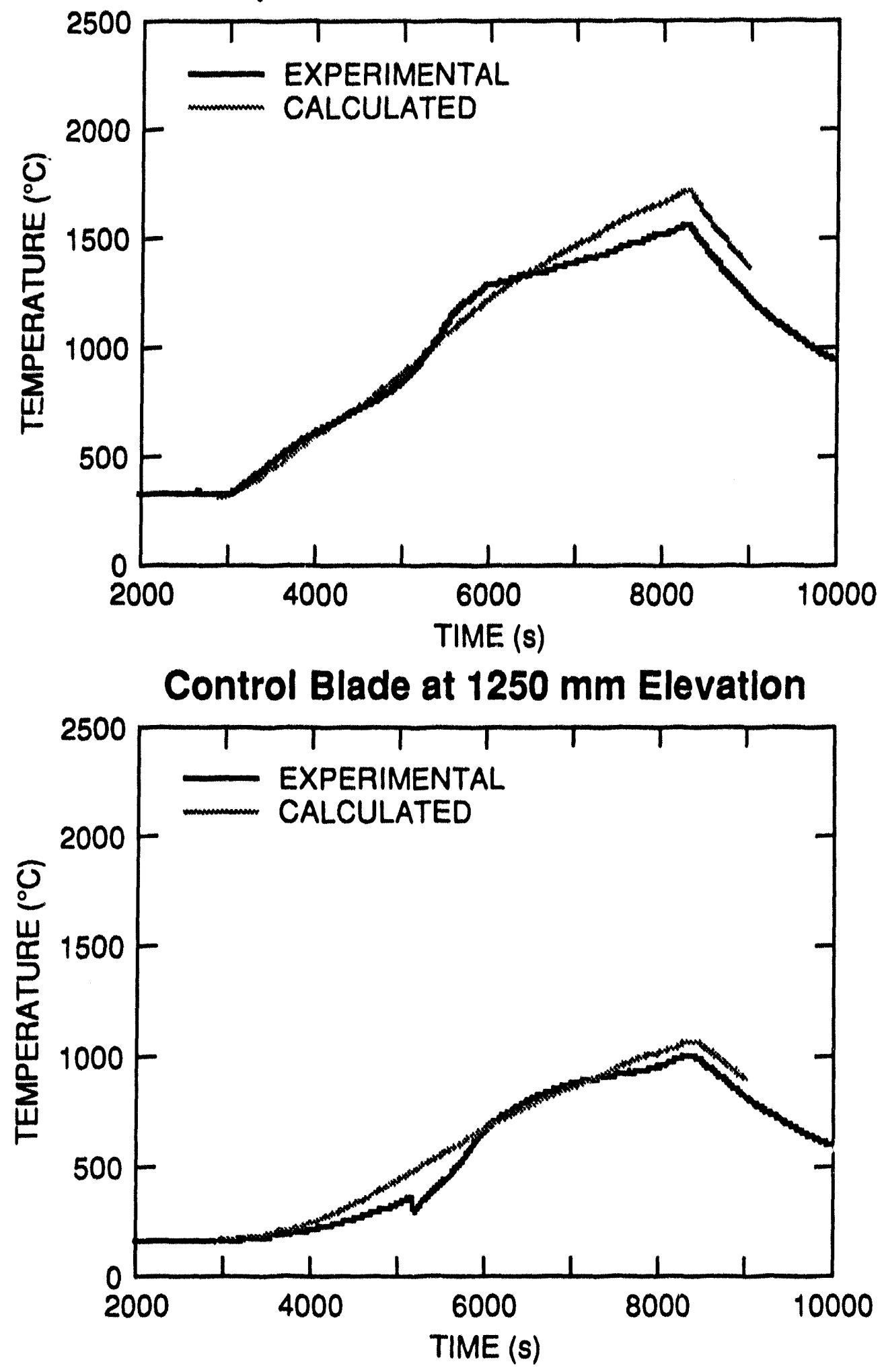

ORNL.DWG 93M-3663 ETD 


\section{CORA-33 Posttest Simulation Results (continued)}

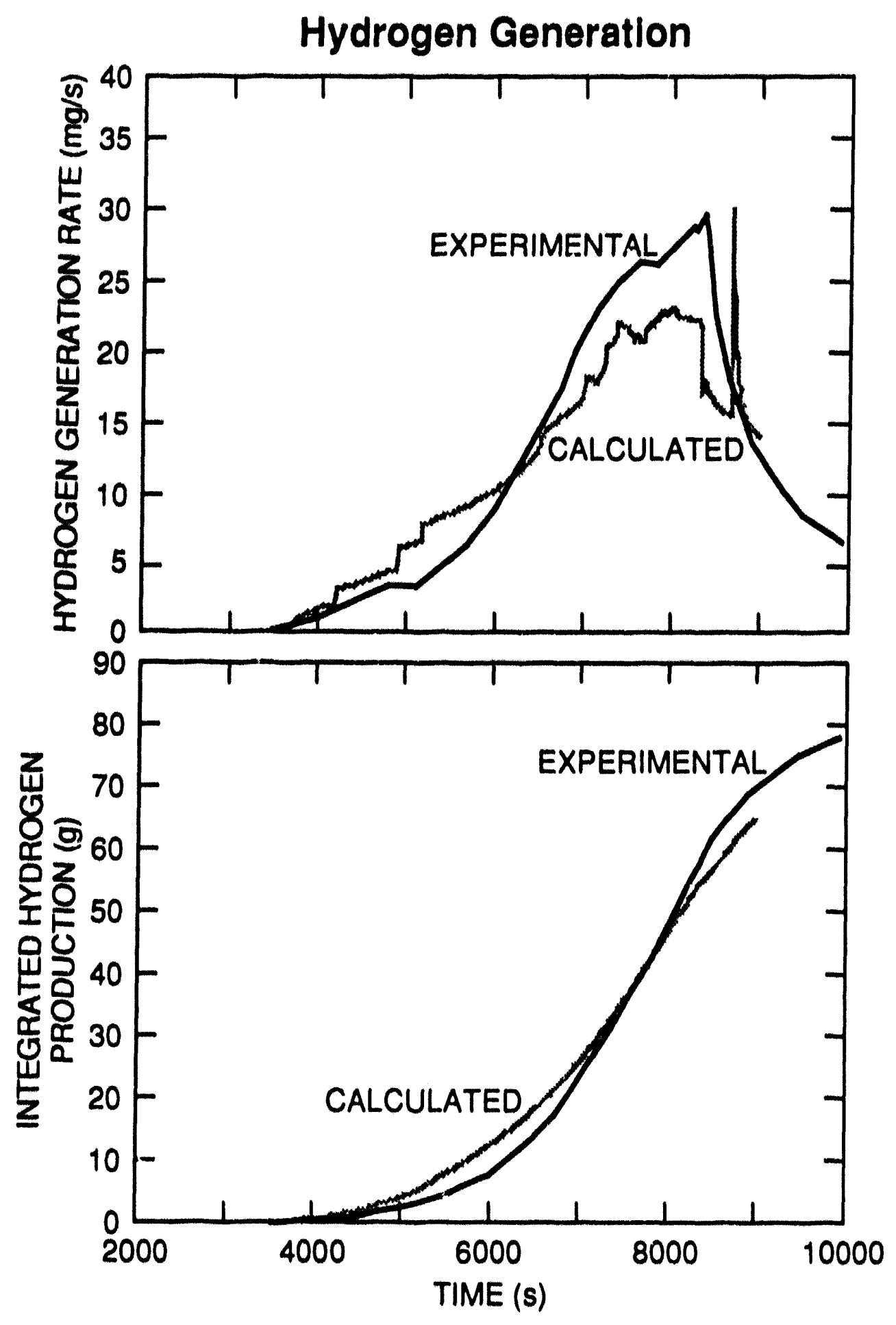




\section{CORA-33 Test Section Relative Blockage}

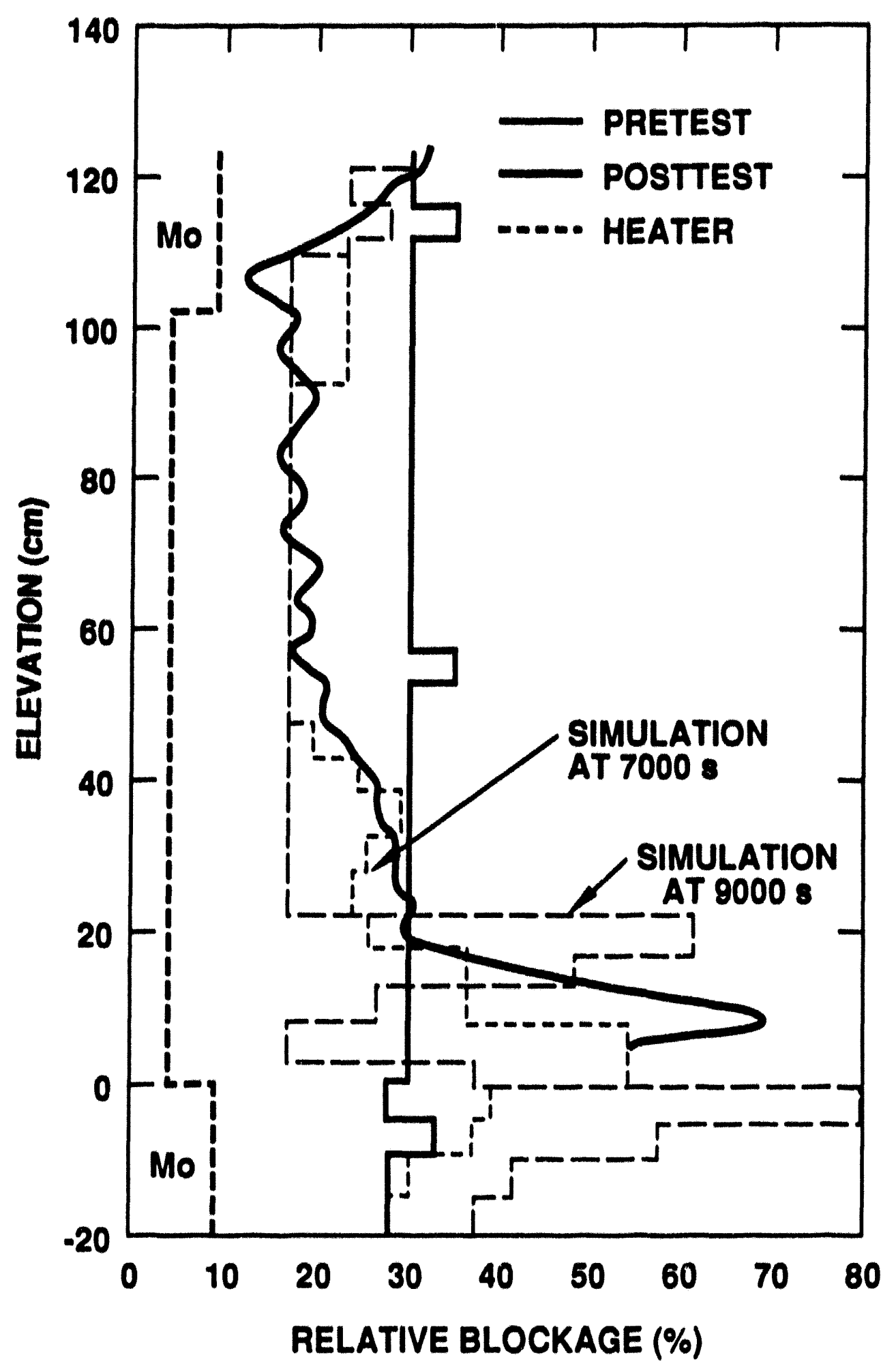




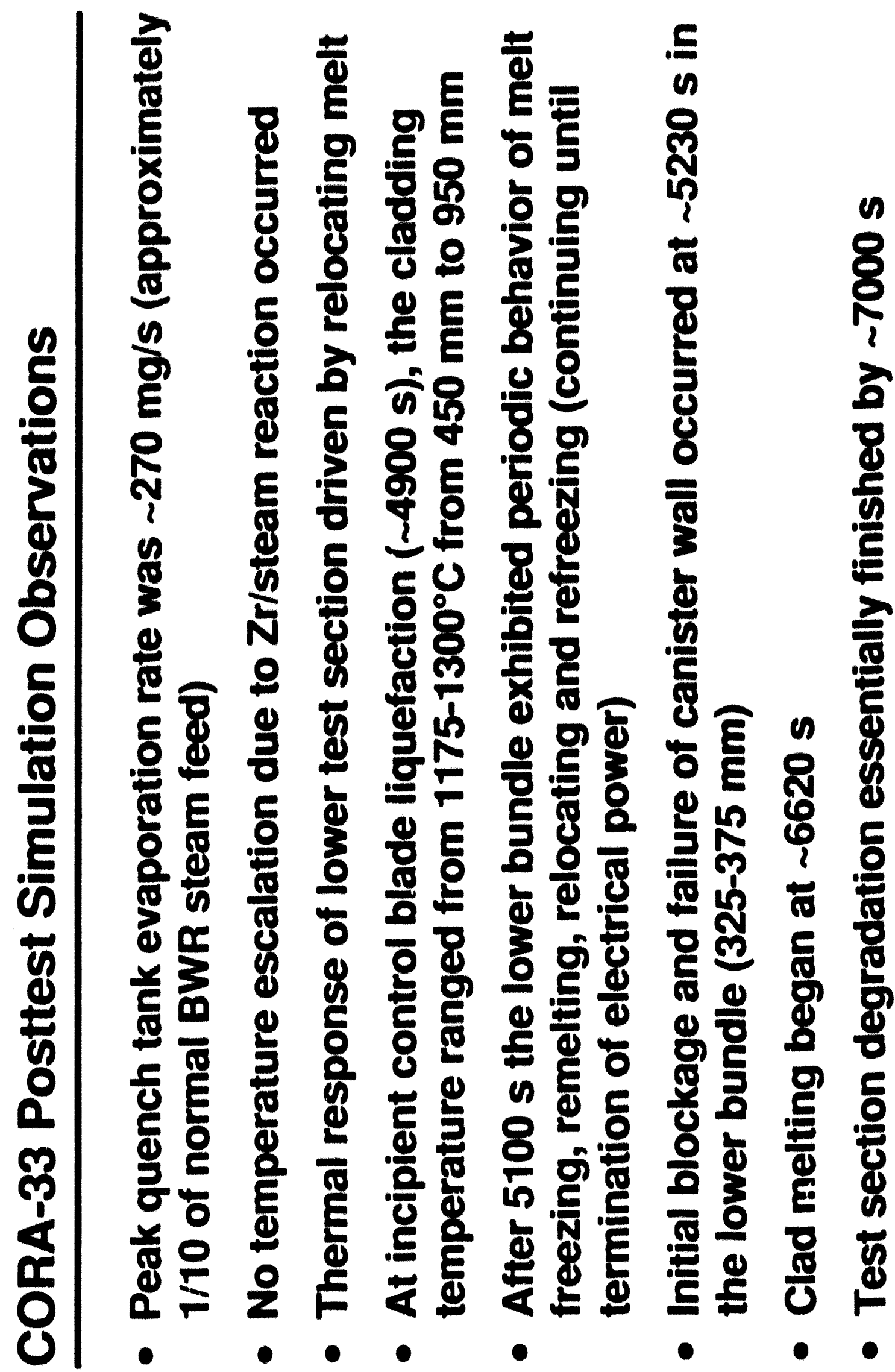

5
8
8
8
8
8
8
8
3
8
8 


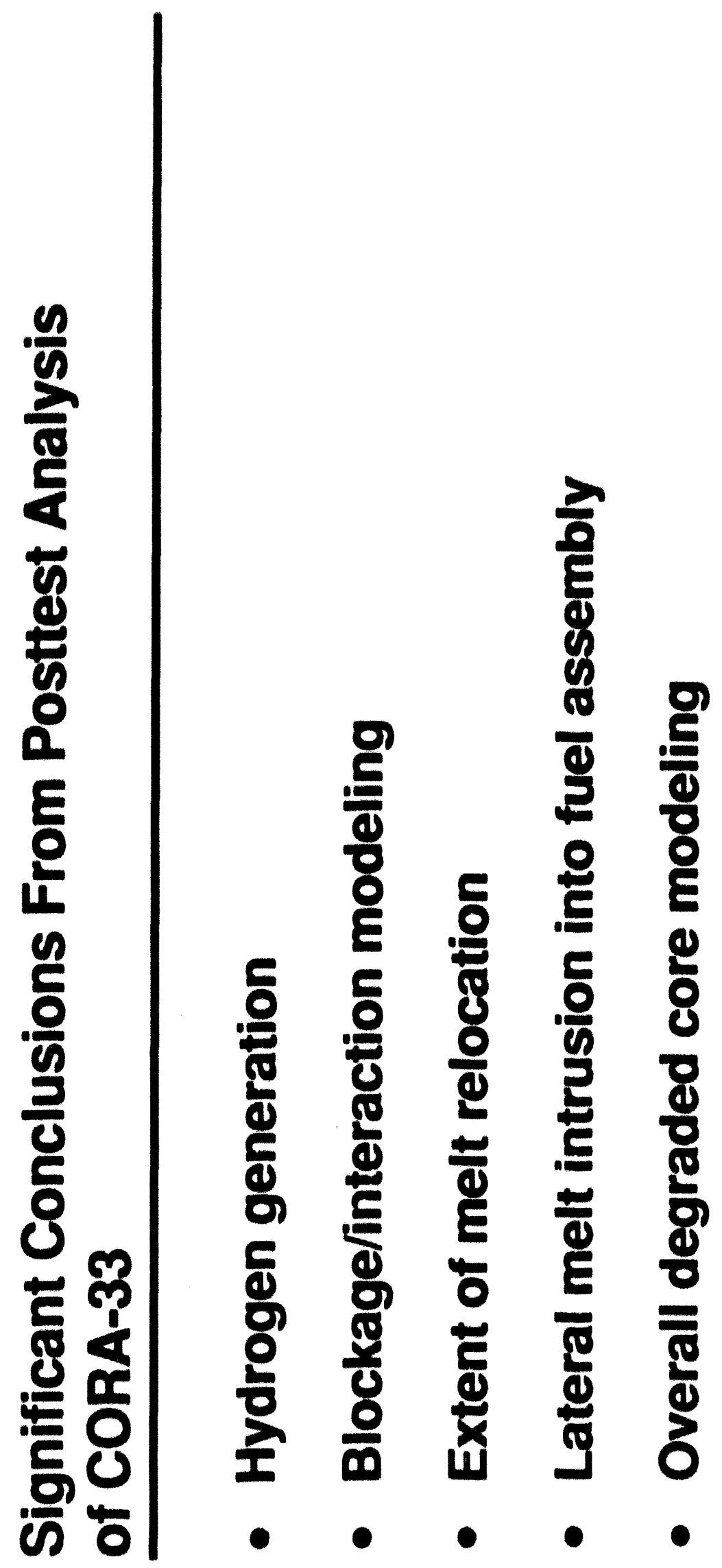




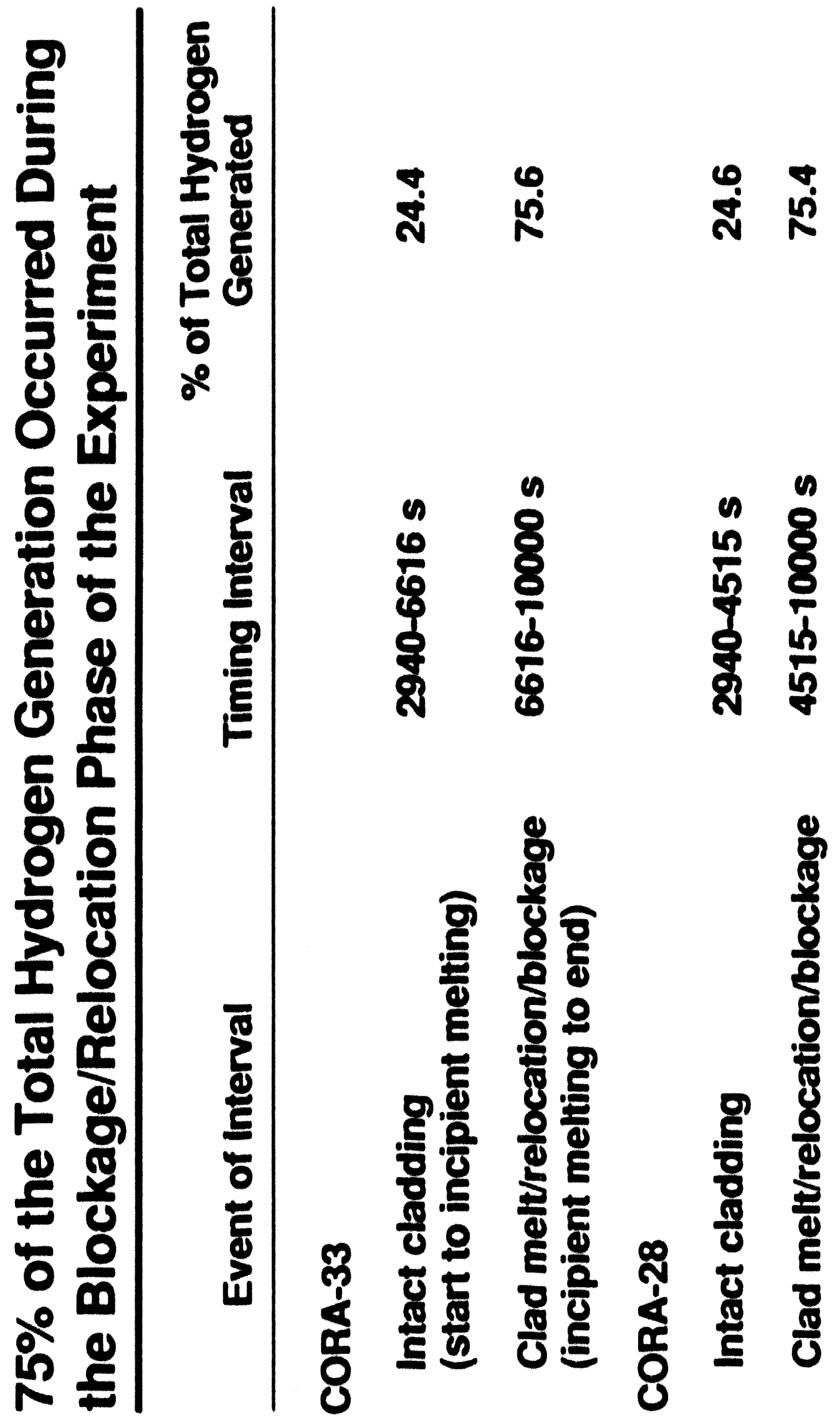


Blockage with $S S / B_{4} C / Z r$ interaction

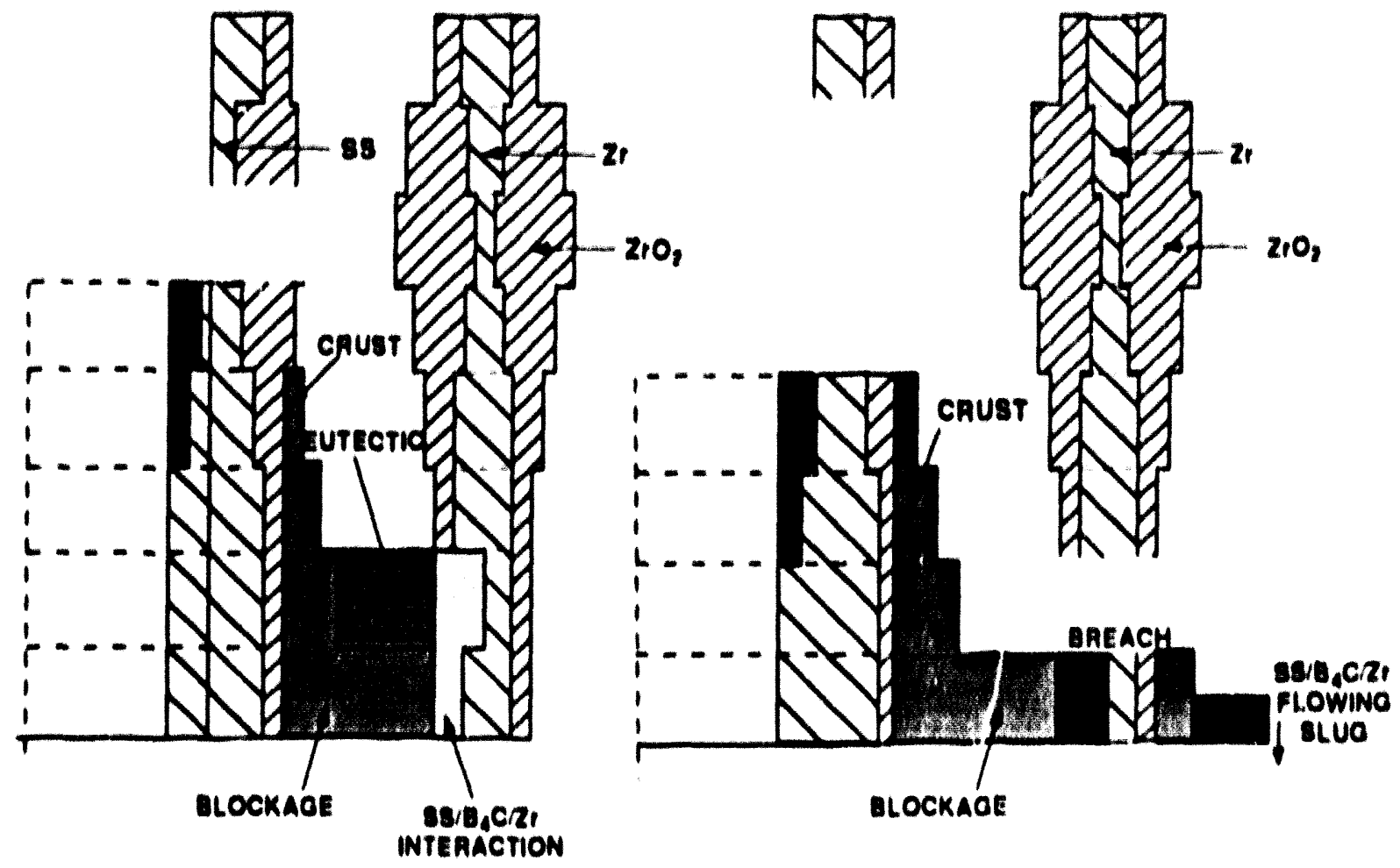

Blockage/lnteraction Modeling

- Developed during CORA-16 and CORA-17 posttest analyses - $1 \mathrm{k} / \mathrm{s}$ Initial heatup rates

- High chemical energy input

- Based on P. Hofman's separate effects studies

- New developmental SCDAP/RELAP5 component*

- Predicted canister fallure times for CORA-31 and CORA-33 too late

- $0.3 \mathrm{~K} / \mathrm{s}$ Initlal heatup rates

- In CORA-33, low chemical energy Input

"F. P. Griffin and K. A. Smith, BWR Control Blade/Channel Box Interaction and Melt Relocatlon Models for SCDAP-Revision 1, letter report (ORNL/NRC/LTR92/12/R1) to Dr. Yi-Shung Chen, Accident Evaluation Branch, Division of Systems Research, RES, USNRC, December 31, 1992. 


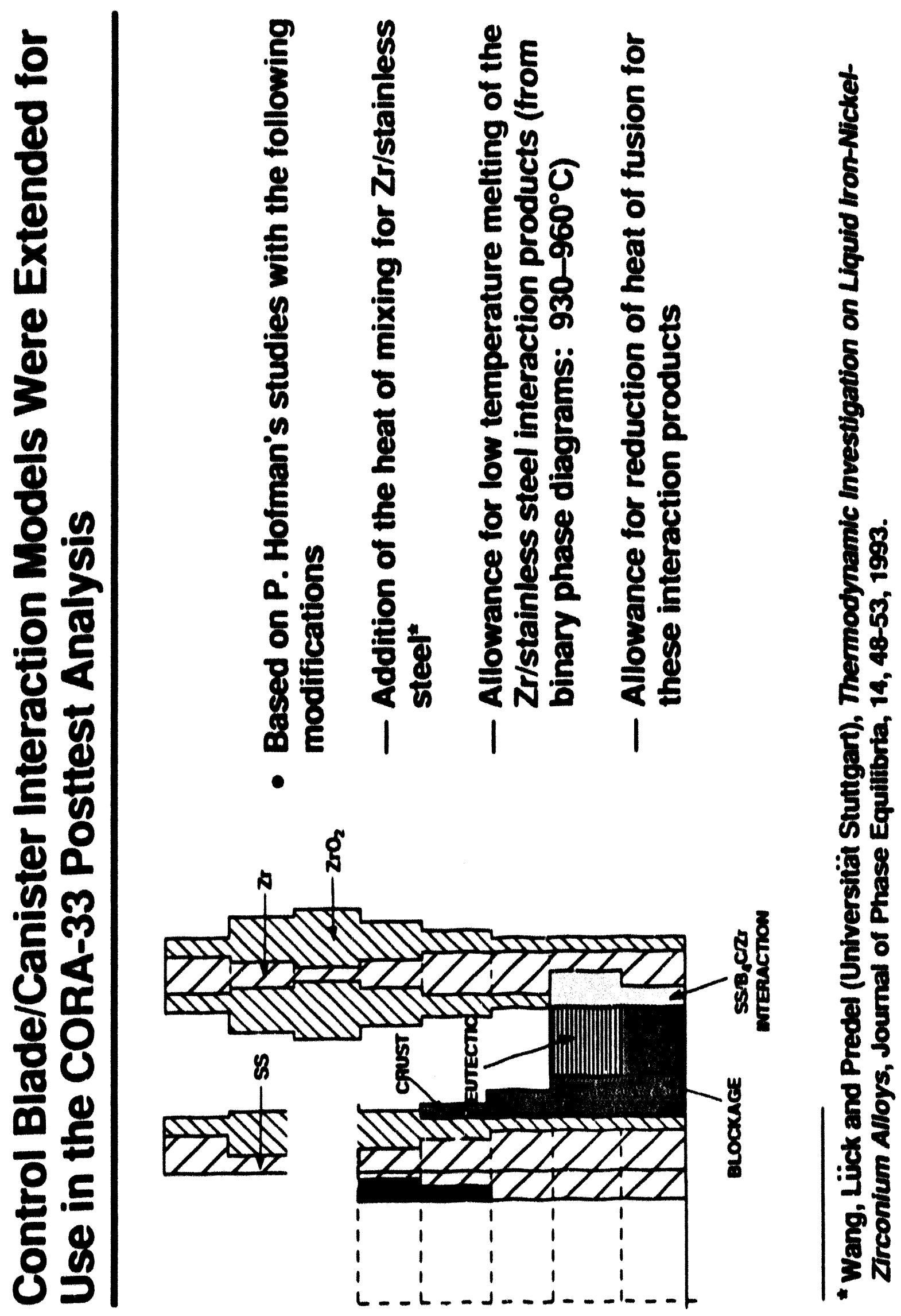




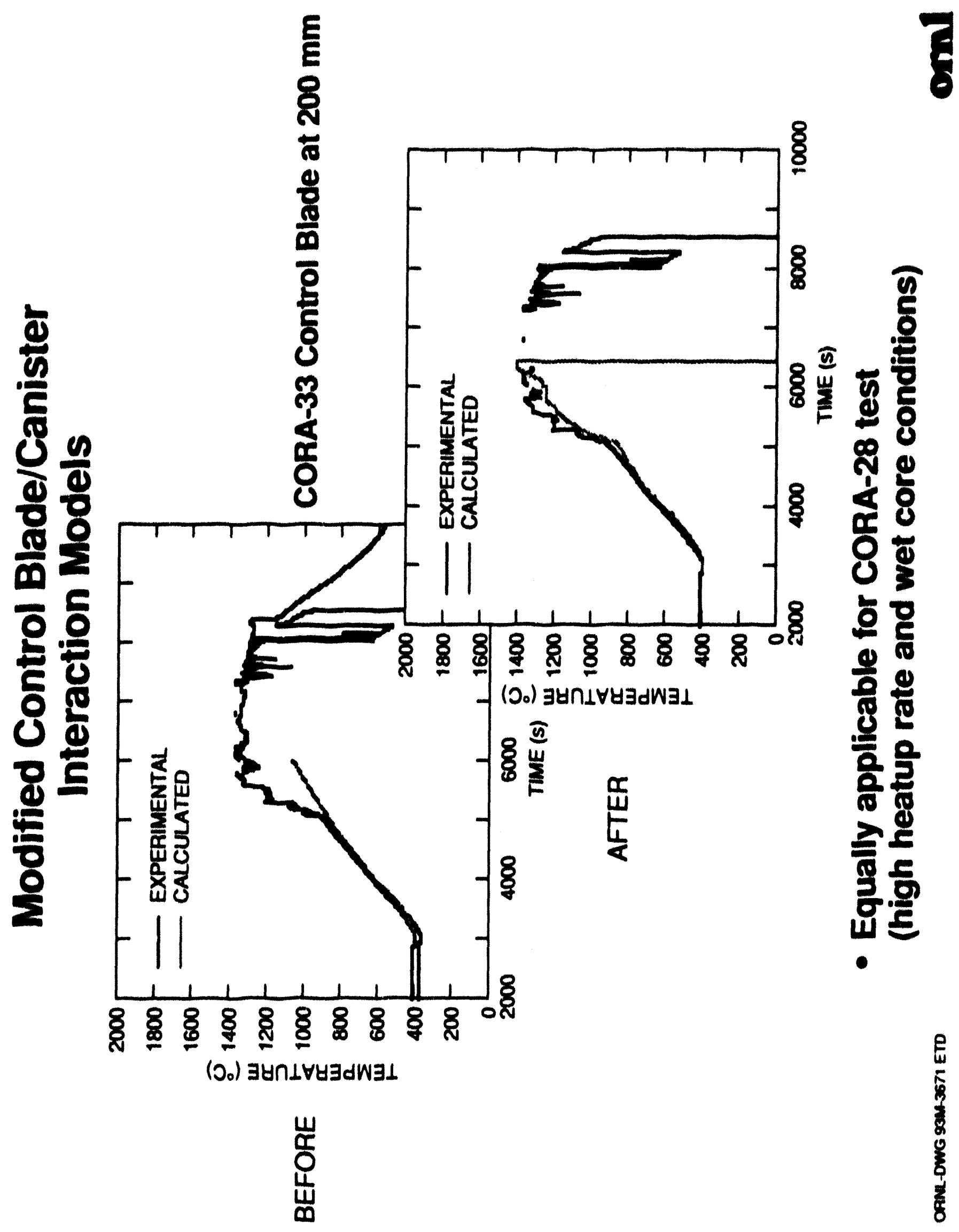




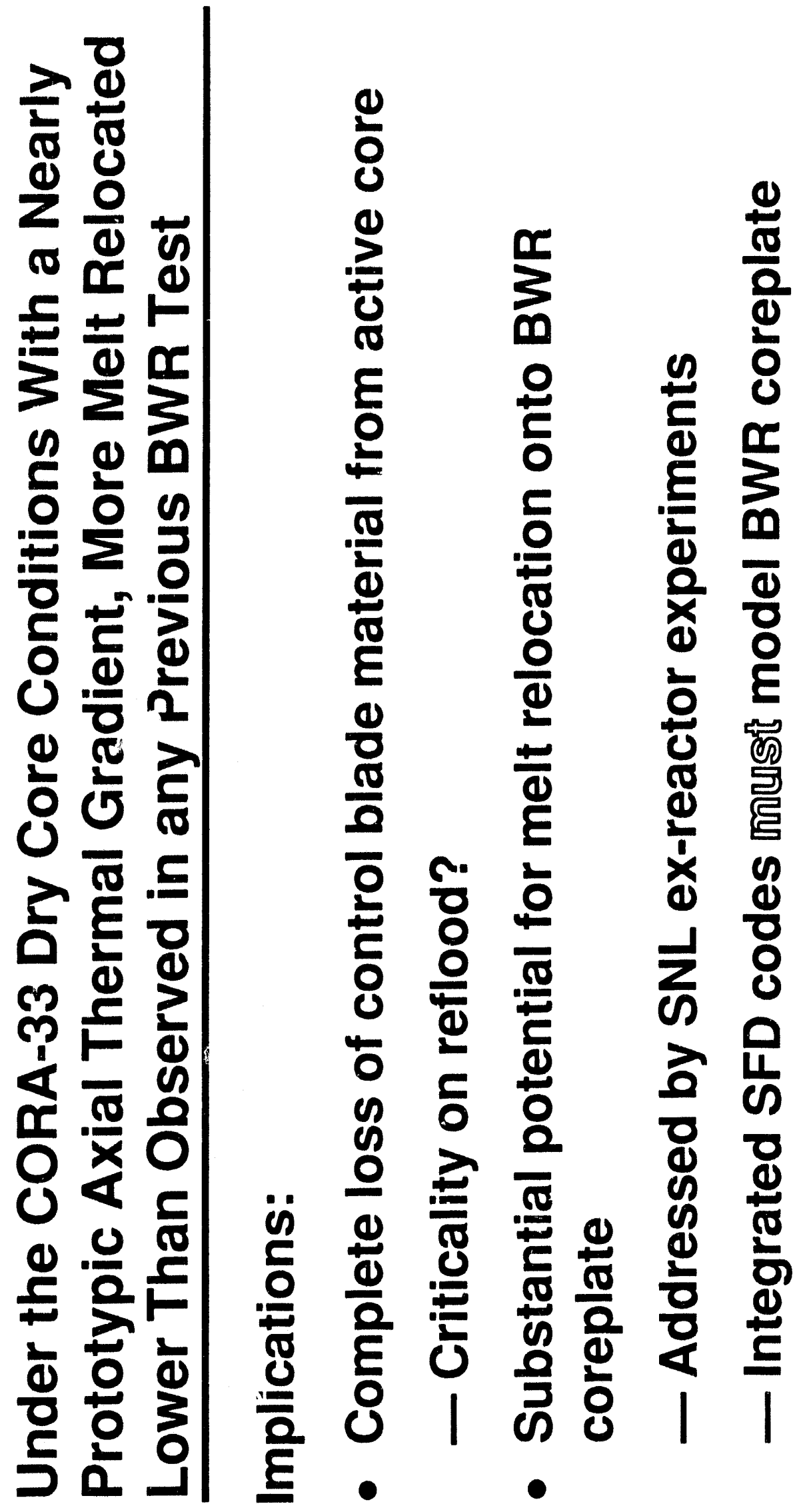




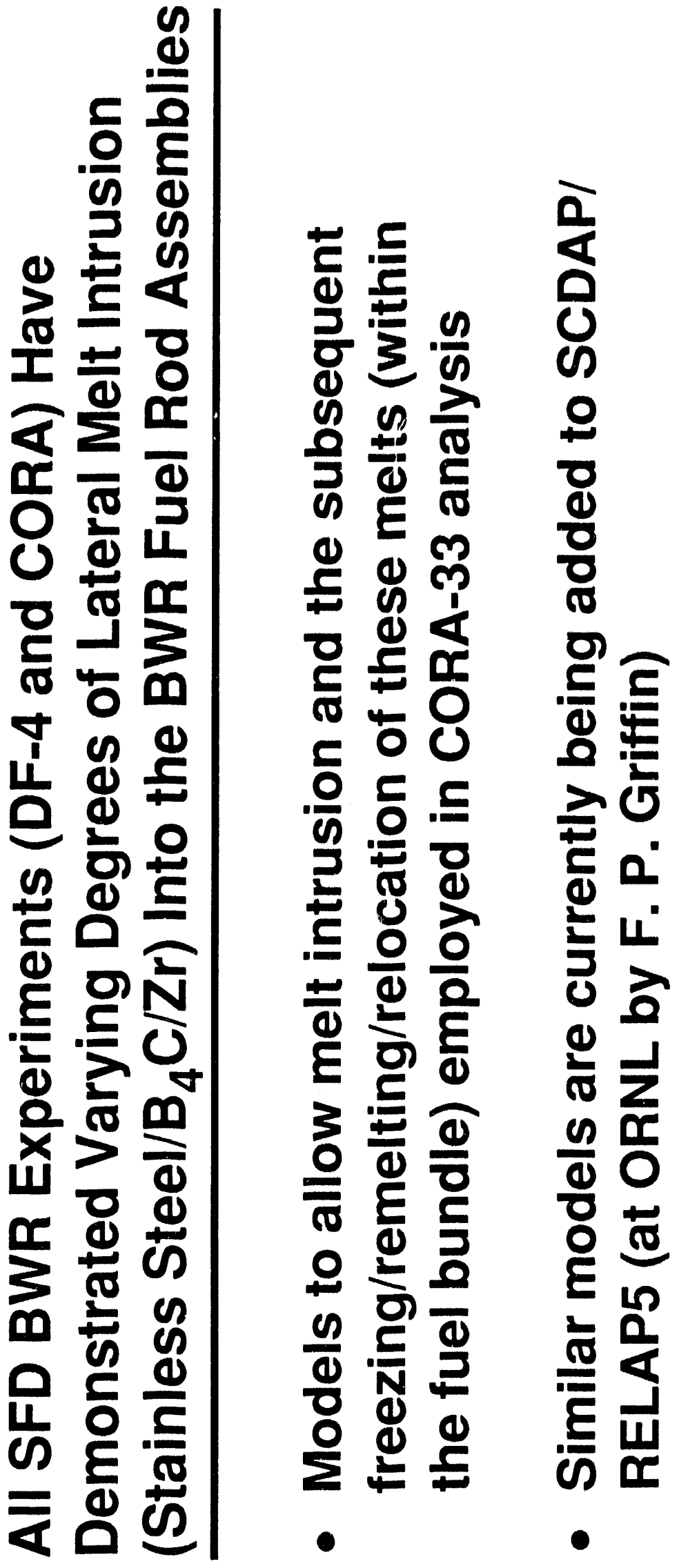




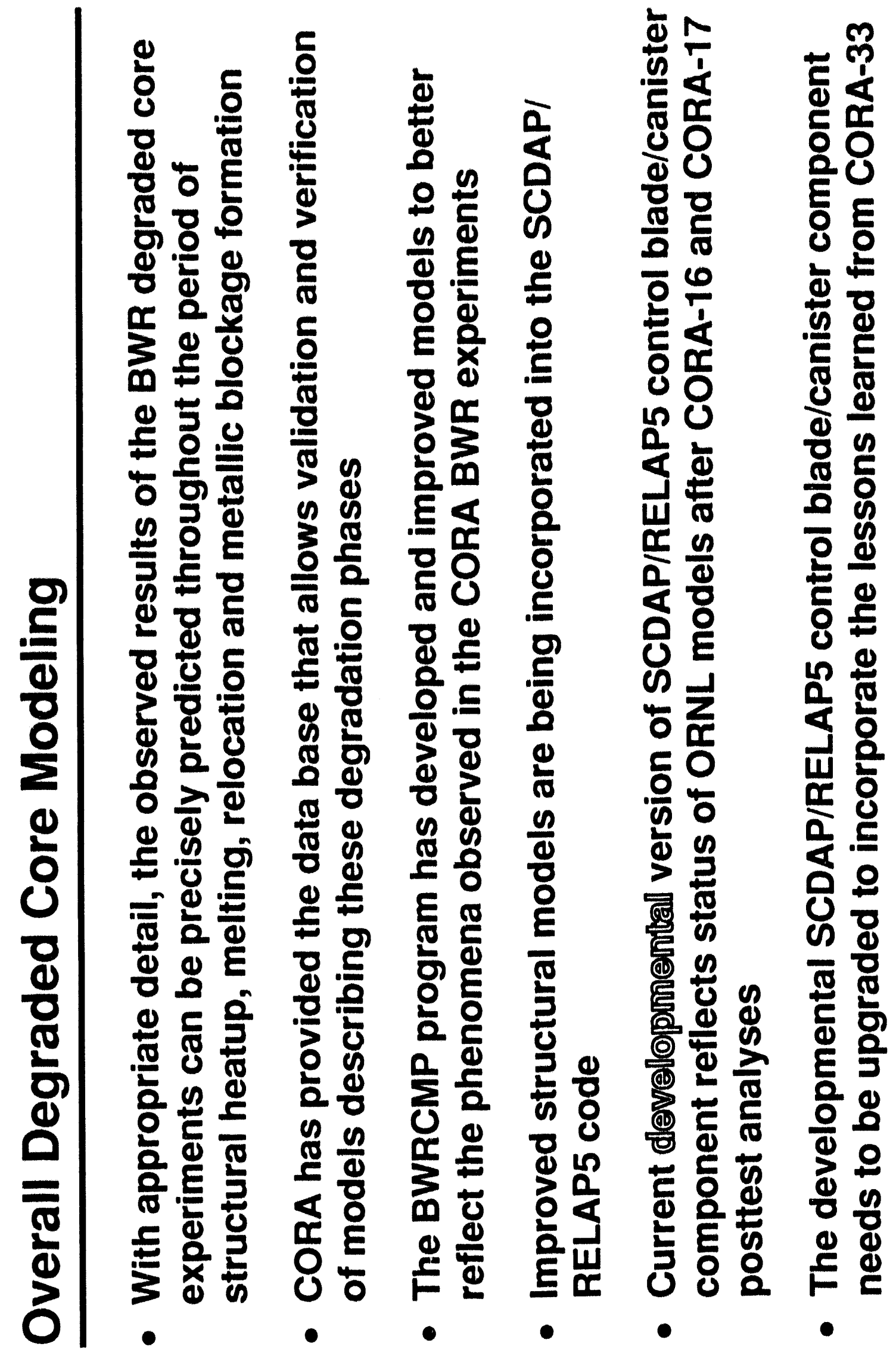




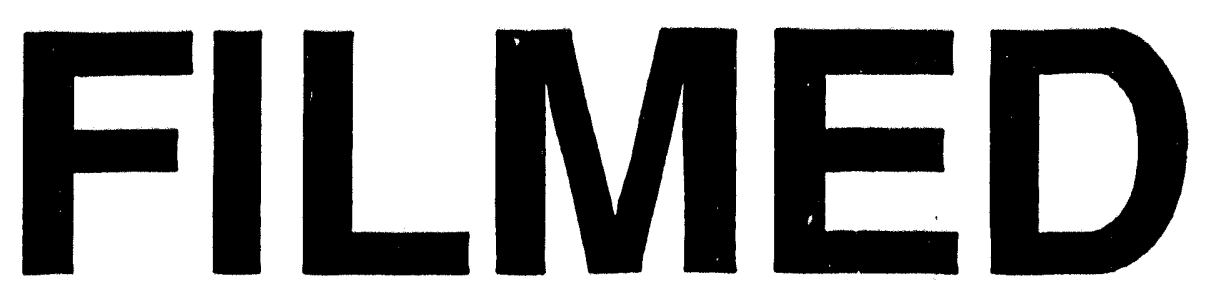

$12 / 22 / 93$
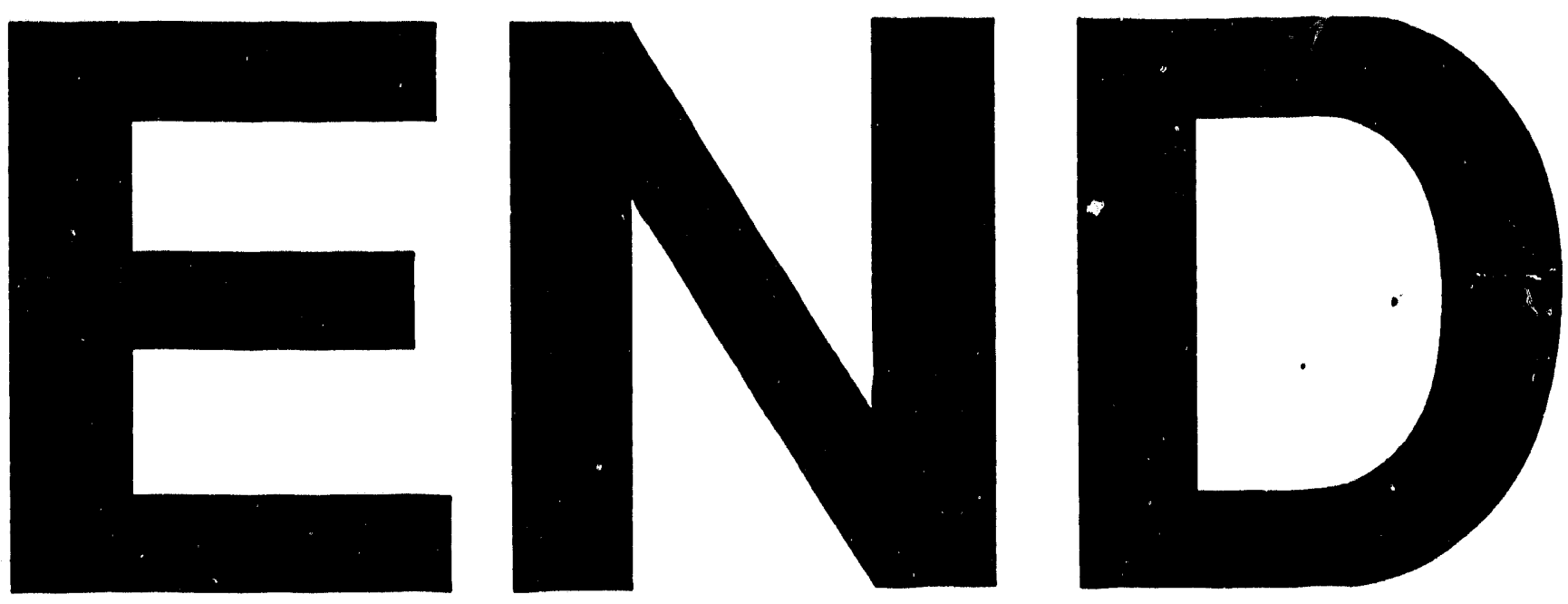
$\longrightarrow$

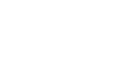

